\title{
Bolesław Hryniewiecki
}

\section{PIERWSZE FLORY OKOLIC WARSZAWY}

WIEK XVII

Pierwszą florę okolic Warszawy opisał w r. 1652 chirurg nadworny króla Jana Kazimierza, M a r c in B e r n h a r d i, nobilitowany w Polsce w r. 1673 pod nazwiskiem de Bernitz. Z powodu tej zmiany nazwiska istniało długi czas pewne bałamuctwo w pracach dotyczących historii botaniki w Polsce. Zasłużony historyk botaniki prof. J. R os t a fi ńs ki, nic nie wiedząc o jego nobilitacji, wyrażał zdziwienie, skąd się wziął dodatek d e B e rn i t z, którego jeszcze za życia swego męża używała jego żona, pisząc łacińskie ody i panegiryki, podpisując się raz Sophia n a Bernardi nata Corbiniana (1664), później zaś Sophiann a Bernardi a Bernitz (1677) i przypisywał to czczej chęci nadania nazwisku szlacheckiego brzmienia przez dodanie nazwy miejscowości, skąd jej mąż pochodził. Przytacza następnie jak to nazwisko zmieniało się u różnych autorów. J. B. D u b o i $\mathrm{S}^{1}$ ) nazywa go raz B e rnitz lub de Bernitz, a drugi raz $\mathrm{M}$ artin $\mathrm{B}$ ernhard, ks. Jundziłł ${ }^{2}$ ) mówi o nim Martin a Bernitz, Arnold ${ }^{3}$ ) spolszcza nazwisko B ernard Bernicki (1), uważając. Bernard za imię chrzestne. Gołębiowski ${ }^{4}$ ) mówi o Bernicjuszu, Gąsiorowski5) zapisuje Bernic Marcin Bernard, za tym wzorem, gdzie Ber-

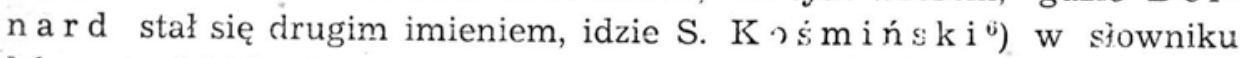
lekarzy polskich (Bernitz Marcin Bernard).

J. R os 1 a fiński wydobył wreszcie na światło dzienne książkę, któ-

1) Essai sur l'histoire litéraire de Pologne. Berlin (1778).

2) Ks. S. B. Jundziłł. Opisanie rośl n. Wilno 1791, p. 43.

3) Rocznik Tow. Warsz. Przyjaciół Nauk. Warszawa 1813. VII. P. 269.

4) Opisanı ri toryczno-starożytne Warszawy. Warszawa 1827. P. 145.

5) Zbiór wiadomości do h:storii sztuki lekanskej w Polsce. T. II, w Poznaniu 1853 , p. 264.

6) L. c. p. 27. 
ra jest drukiem niezmiernie rzadkim, przedrukował ją całkowicie, dodał swoje komentarze i przerobił podane tam katalogi roślin ogrodów królewskich na spółczesny język botaniczny. Tytuł książki brzmi: „Catalogus plantarum tum exoticarum quam indigenarum quae Anno MDCLI in hortis Regiis Warsaviae et circa eandem in locis sylvaticis, pratensibus, arenosis et paludosis nascuntur collectarum... a chirurgo Martino Bernhardo. Dantisci 1652 “. Z powodu złego złacińszczenia nazwiska autora, który właściwie nazywał się B ernhardi (winno być a Bernhardio), Rostafiński ustalił brzmienie nazwiska na „B ernhard“ i ja również, idąc za jego autorytetem, trzymałem się tej nazwy w swoich Zarysach historii botaniki w Polsce, zarówno w języku polskim jak i francuskim ${ }^{1}$ ). Tymczasem na str. 4 wydanej przez prof. R ostafińskiego pracy w rekomendacji autora przez dr Wilhelma Davidssona, ówczesnego dyrektora królewskich ogrodów i apteki wyraźnie stoi ,pro Dr Martino Bernhardi“. Brzmienie nazwiska ostatecznie ustalił i rozwikłał całe to bałamuctwo Aleksander Birkenmajer, drukując w Polskim Słowniku Biograficznym jego życiorys ${ }^{2}$ ) i stwierdzając dokumentalnie, że w r. 1673 Marcin Bernhardi został nobilitowany jako de Bernitz. Okazuje się, że poważni bibliografowie jak J. Ch. A d elung ${ }^{3}$ ) i Karol Estre i c h e ${ }^{4}$ ), nie popełnili błędu, wbrew temu co twierdził R os tafińs ki, podając 1) „Bernhardi de Bernitz Martin“ i 2) „Bernhardi Martin de Bernitz".

Spis roślin okolic Warszawy jest trzecim z rzędu katalogiem (str. 57 do 80) w wyżej wymienionej książce; dwa pierwsze są to spisy roślin hodowanych w dwóch królewskich ogrodach botanicznych, pierwszego podmiejskiego (suburbani) z Ujazdowa, gdzie była od czasu książąt Mazowieckich rezydencja królewska i drugiego (sub Arce Regia) na tyłach pałacu Kazimierzowskiego, gdzie z początku istnienia Uniwersytetu Warszawskiego był jego pierwszy Ogród Botaniczny, a po odzyskaniu niepodległości Ogród farmakognostyczny. Te dwa spisy są podpisane przez ogrodników: włocha Bartolomeo Gei i morawianina Jakuba $\mathrm{Haicka}$.

B ernh ardi był redaktorem całości i wyłącznym autorem spisu roślin okolic Warszawy.

M a r cin Bernhardi urodził się w r. 1625, pochodził ze Sląska Łużyckiego, pełnil obowiązki chirurga, a po roku 1663 występował jako lekarz i bibliotekarz królewski; w charakterze chirurga brał udział w wy-

1) B. Hryniewiecki. Historia botaniki w Polsce. Poradnik dla samouków. T. VII. Botanika II. 1927, str. 699-743.

2) Polski Słownik Biograficzny wyd. przez P. Akad. Um. w Krakowie. T. II.

3) Fortsetzung zu Gelehrten Lexicon. Leipzig 1784, p. 1749.

4) Bibliografia. T. XII, p. 506. 


\section{PROOEMILM EDITORIS.}

Anno 1052 prodiit in lucem Gedani liber, cuius titulus, ad similitudinem archetypi accuratissime expressus, sequitur talis:

\section{CATALOGVS \\ P LA N TA R V M}

Tum exoticarum quam indigenarum quae Anno II. DC. L.I. in hortis Regiis Warfavitu

Et circa eandem in locis fylvuticis, pratenfions, arenofis \& paludofis nafenn-

(tir) collectarum. exhibitus

Serenißimo ac Polentißimo Demino, DN. JOHANNI CASIMIRO III. POIONIAE ET SVECIAE REGI, IA. GNO DUCI LITINANIAE \&c. \&c.

Dno. suo Clementiffimo.

Suae Haj. Regine

Subjectibime Famulo \& Chirurgo

MARTINO BERNHARDO.

\section{DAN TISC I.}

Sumptibus Enefti \& Andreae Julij, Mollerorum Fratr: S. K. M Bibliopo-

$$
\text { lar: } 116 \quad 52
$$


prawach hetmana Michała Paca i został odznaczony jako żołnierz odważny; za Michała Korybuta trzymał się nadal dworu i był sekretarzem królewskim.

Miał on wielkie zamiłowanie do przyrody i zajął się nie tylko zbadaniem flory okolic Warszawy, lecz pierwszy w Polsce stworzył poważne prywatne muzeum przyrodnicze. Relację o tych zbiorach będących osobliwością Warszawy znajdujemy w pracy o Polsce Anglika, chwilowego lekarza Jana Sobieskiego Bernarda $\operatorname{Connora}{ }^{1}$ ), który zwiedzał ten gabinet przyrodniczy już po śmierci jego twórcy. Oprowadzała go wdowa $\mathrm{Z}$ ofia Anna z domu Corbiniani mówiąca biegle po łacinie, w tym języku dając wyjaśnienia. Connora uderzyły przede wszystkim liczne skamieliny, jak okazy skamieniałych drzew, węży (były to prawdopodoknie amonity i Ophiuridae), ropuch i nawet winogron. Paleontologia była wtedy w powijakach, zbierano więc takie okazy jako curiosa, dopatrując się w nich podobieństwa do różnych przedmiotów. Była tam rzadka kolekcja muszli, minerałów i różnych gatunków żywic. Zwrócił on także uwagę na przyrząd ze szkła ze skalą, gdzie ciepło ręki powodowało wznoszenie się alkoholu; był to więc termometr alkoholowy. Poza tym były w tym muzeum rogi łosia i duża ilość rogów innych zwierząt oraz roślin zasuszonych i naklejonych na papier; prócz tego duża ilość rysunków różnych okazów przyrodniczych odrysowanych własnoręcznie przez B e r n h a rdi e g o. Zbiory te zostały przez syna twórcy muzeum sprzedane ks. Dominikowi Radziwiłłowi, kanclerzowi W. Ks. Litewskiego za 6000 talarów i umieszczone w palacu przy ulicy Miodowej, gdzie zginęły przy pożarze; na tym miejscu wzniesiono później pałac Paca (później sąd okręgowy).

B ernhardi $\dot{z} y w i ł$, widocznie, duże aspiracje naukowe i swym zamiłowaniem do nauk przyrodniczych wyrastał znacznie ponad sferę zwykłych chirurgów i pragnąc zostać doktorem medycyny, drukował oprócz katalogu pewne prace treści lekarskiej w Miscellanea curiosa medicophisica Academiae Naturae Curiosorum w Lipsku w r. 1671 i 1672 . Zdawało się, że jego życzenia mają się urzeczywistnić, gdyż dzięki protekcji kardynała Vidoniego, nie kez wpływu prawdopodobnie króla, ktory bardzo mu sprzyjał, otrzymał on w Boionii w r. 1663 (3. XI.) dyplom doktora medycyny, lecz 21. XI. nastąpił rzadki wypaciek w dziejach uniwersyteckich - annulacja dyplomu. Widocznie w ostatnich chwilach rozmyślono się i spostrzeżono, że kandydat nie ma odpowiedniego przygotowania do

1) The history of Poland by Bernhard Connor M. D. Vol. II. London 1698. To samo w tlumacz. n em •eckim pt. B. Connor. Beschreibung des Kònigreichs Polen. Leipzig, 1700, p. 783 i 784. 
naukowego tytułu. Data śmierci B e r n hardiego nie jest znana, w każdym razie zmarł on przed rokiem 1682.

Książka B e rnhar di e go dedykowana królowi Janowi Kazimierzowi ma na wste.pie ówczesnym zwyczajem zalecenia w górnolotnym stylu dwóch uczonych mężów, stojących z nim w bliskich przyjacielskich stosunkach i pracujących razem na królewskim dworze.

Pierwszym jest Andrzej Knoeffel (Andreas Cnoeffel i u s), lekarz nadworny króla Władysława IV I Jana Kazimierza. O nim tak pisze A rnold ${ }^{1}$ ), „Wielu też cudzoz:emców nie na próżno ze stratą ojczystej ziemi na polską zamienili. Tak Andizej Knoeffeliusz, Niemiec z familii Chimików pochodzący, królów Władysława IV i Jana Kazimierza nadworny lekarz, tajemnych lekarstw przedawca do takich tu b’gactw przyszedł, że powszechnie mówiono, że Polskę przedażą sekretnych preparatów złupił“.

Drugim z kolei zalecającym książkę $\mathrm{B}$ ernhardiego był Wilh elm Dawidsson, również tytułujący się nadwornym lekarzem króla i królowej poza tym przełożony laboratorium chemicznego i ogrodów królewskich (Hortorum Regiorum et Laboratorii Chemici supremus praefectus). Był to uczony Szkot i profesor chemii w Paryżu, skąd został powołany w r. 1651 do Warszawy, gdzie pozostawal przez lat 17 . Był to człowiek światły, który rozumiał, że kołtun, tak rozpowszechniony wówczas w Polsce, nie jest żadną chorobą włosów, lecz pochodzi z niechlujstwa. Pisząc o tym i zwalczając przeciwne zdania, wspomniał, że w Polsce usunął kołtuna tysiącom osób bez szkody dla zdrowia. To tak zwane Laboratorium Chemiczne, na którego czele stał ów Daw idsson było właściwie apteką królewską, do której dostarczano materiałów w postaci licznych ziól lekarskich, które, jak widać ze spisów, dostarczano z dwóch ogrodów królewskich, a Bernhardi, jako znający się na florze, mógł niejedno dorzucić z roślin lekarskich dziko rosnących w okolicach Warszawy. W pracowni Dawidssona preparowano rośliny, suszono, krajano, oczyszczano, gotowano i przepędzano ciecze, robiono wódki, olejki, mydła wonne i rozmaite leki na potrzeby dworu. Stąd zrozumiałą rzeczą jest połączenie w jednej osobie Dawidssona dwóch funkcji: kierownika apteki i ogrodów królewskich. Rzecz wiadoma, że D a w ids s o n czuł się w kitanice mniej silnym niż w chemii lekarskiej i, ceniąc pracę B e r n h a rdi e g o, który wykonał na owe czasy trud niemały, zebrawszy i oznaczywszy według ówczesnych bardzo bałamutnych źródeł rośliny zebrane w okolicach Warszawy, nie podpisał dostarczonych przez ogrodników

1) A rnold. O hojności królowi i względach panów polskich dla rzeczy lekarskich i lekarzy. Roczn. Tow. Warsz. Przyjaciół Nauk 1813. T. VII. D u b o is. Essai sur l'hıstoire li.téraire de Pologne. Berlin. 1778. 
katalogów roślin hodowanych w królewskich ogrodach botanicznych, których był naczelnym kierownikiem, lecz całkowicie zdał się na B e r $\mathrm{n}$ h a rdi e g o. Ostatni okazał się złym redaktorem, bo wypuszczając w świat książkę nie uzgodnił nomenklatury katalogów, gdzie często jedna i ta sama roślina figuruje pod różnymi nazwami.

Wydanie tych katalogów drukiem miało duże znaczenie, jako wymowne świadectwo istnienia w Polsce w XVII wieku ogrodów botanicznych w Warszawie. Nie były one uboższe od innych, jak to okazało się z wydanej w Kopenhadze w rok po wyjściu książeczki B e r n ha r d i e g o książki Simona Paulliego (1603-1680) pt. „Viridaria varia regia et academica publica“ ( $\mathrm{H}$ a $\mathrm{f} n$ i a e 1653), gdzie przedrukowano oba katalogi z Warszawy obok katalogów z innych ogrodów królewskich lub uniwersyteckich - w Kopenhadze, Paryżu, Oksfordzie, Padwie, Lejdzie i Gronindze.

Prof. J. R o s t a f i ń sk i, interesując się historią hodowli roślin w Polsce, przedrukowując prawie nieznaną, z powodu rzadkości, pracę B e rn$\mathrm{h}$ a r d i e g o, zadał sobie trud przełożenia nazw roślin obydwu katalogów na spółczesny język botaniczny.

Pozostała jednak nieopracowana flora okolic Warszawy, która jako pierwsza zasługuje na specjalną uwagę. Dlatego też podjąłem się jej opracowania, miałem przy tym pracę znacznie ułatwioną przez swego poprzednika, gdyż mnóstwo nazw roślin z katalogów ogrodów powtarza się i w katalogu roślin okolic Warszawy.

Praca Bernhardiego spotkała się zarówno z poważną krytyką, jak i ze złośliwymi uwagami bez argumentów rzeczowych.

Tego rodzaju uwagi ogłosił Chrystian Henryk Erndtel, lekarz nadworny Augusta II, w dziele pt. „Warsavia physice illustrata“ (Drezno 1730), gdzie oprócz opisu miasta Warszawy i jej warunków przyrodzonych i stanu zdrowotności został dołączony spis roślin dziko rosnących w okolicach Warszawy (Viridarium Warsaviense). O swoim poprzedniku Erndtel w ten sposób się wyraża: „Chirurgus enim professione fuit simplex, litterarum penitus ignarus et quas ad Collegium N. C. G. misit Observationes, non ipse, sed alii Latinitate donarunt, quod et de Catalogo Plantarum Varsaviensium suo teriendum, in quem innumera ex ignorantia Latinitatis et Botanices irrepserunt vitia“ (l. c. p. 211).

$\mathrm{Z}$ wysokości swego doktorskiego tytułu Erndtel mówi o Bernh a r dim, że to był prosty felczer, nie biegły w nauce, a to co pisywał w Aktach Naturae Curiosorum w Lipsku po łacinie, to mu inni tłumaczyli, że w katalogu są niezliczone błędy wynikłe z ignorancji autora pod względem botanicznym i znajomości łacińskiego języka. Pierwszy argument o niskim stanowisku społecznym autora nie wytrzymuje krytyki; inaczej patrzyli na swego kolegę dw̉aj wybitni lekarze nadworni króla Ja- 
na Kazimierza, którzy tę pracę polecali. Śmiesznie wygląda argument, że łacińskie prace umieszczone w Academia Naturae Curiosorum ktoś mu tłumaczył; wiemy dzisiaj, że Bernhardi miał żonę nie tylko biegle władającą łaciną, lecz piszącą ody w tym języku, jeżeli więc dopomagała mężowi $\mathrm{w}$ tej sprawie, to mogło tylko być z korzyścią dla tych prac. Stwarzając nie byle jakie muzeum przyrodnicze, Bernhardi dowiódł, że nie był wcale

\section{Viridarium Warfavienfe}

five

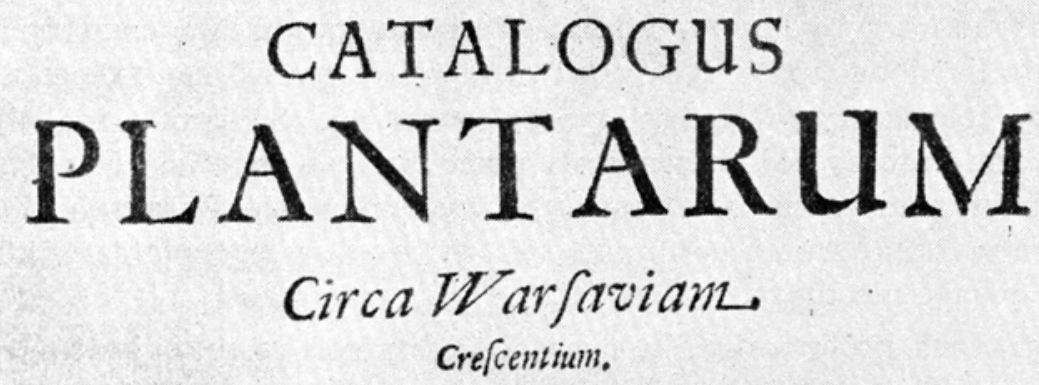

Rys. 2

naukowym ignorantem, przedsiębiorąc zaś badanie roślin okolic Warszawy, miał stokroć trudniejsze zadanie wobec ubogiej i nieuporządkowanej literatury systematycznej niż jego następca w 80 lat później w myśl zasady „Facilius est instructis addere quam nova collocare fundamenta“ (łatwiej jest uzupełnić to co już zostało zbudowane, niż tworzyć nowe fundamenty). Tymczasem o pracy Erndtla tak pisał ks. S. B. J undziłł ${ }^{1}$ ): „Wkrótce po nim Krystian Erndtel, medyk nadworny Augusta II mało co porządniejszy roślinny katalog podał; wiele w całym kraju pospolitych opuścił, wątpliwe za pewne umieścił, Grzybów klasę z H o f$\mathrm{m}$ a n a co do słowa wypisał, żadnych własnych obserwacji nie położył“.

1) Ks. S. B. Jundziłł. Opisanie roślin W. Ks. L... Wilno 1791. 
Z rzeczową krytyką wystąpił botanik wyższej miary, jakim był A lbert von $\mathrm{H}$ alle $\mathrm{r}^{1}$ ), który w ten sposób pisał o książce M. B e rn$\mathrm{h}$ a r die g o: „Ut plerique cuismodi catalogi nomina habent absque synonimis et varietatibus. Alicuius momenti fuerit appendix, in qua plantae continentur, quae ex Hungaria anno 1650 in hortum translatae sunt, inter eas multae enim variores si verae spontaneae sunt, utique continentur aliquae, quae vix intelligas, ut Bardana coerulea, Elleborus niger flore coeruleo. Plantarum indigenarum et circa Varsaviam nascentium catalogus continet Allium alpinum, Ariam Theophrasti, Asarum angustifolium, Asclepiadem nigram, Barbam Jovis, Momordicam, plurimas alias plantas, guas sponte eo sub coeio nasci improbabile est". (Jak większość tego rodza-ju katalogów zawiera nazwy roślin bez odmian i synonimów. Pewną wartość miałby dodatek ze spisem roślin przesłanych do Ogrodu w r. 1650 z Węgier, wśród których są wątpliwe, czy są dzikie, zwłaszcza są i takie, które trudno zrozumieć co oznaczają jak (p. wyżej) i dużo innych, co do których można wątpić, czy mogą rosnąć w naszym klimacie). Zupełnie słusznie $\mathrm{H}$ alle r wypomina autorowi, że nie umieścił synonimów, dziẹki którym można by łatwiej zrozumieć o jakim gatunku mowa. Gdy jeszcze nie była ustalona przez L in n e u z a ścisła podwójna riomenklatura, autorzy charakteryzowali rośliny często całymi zdaniami i niejedną roślinę różni autorzy różnie nazywali, powołanie się więc na pewnych autorów i użyte przez nich nazwy mogłyby wyjaśnić wiele. Poza tym $\mathrm{H}$ a ll e r od razu wytknął szereg gatunków, które według jego zdania w klimacie Polski rosnąć nie mogą.

O ogrodach królewskich, których dokładny spis roślin ogłosił w r. 1652 M a r c in B e r n h a r d i, mieliśmy już wcześniejszą relację w rymowarym opisie Warszawy pt. „Gościniec“, jaki wydał za Władysława IV w r. 1643 skrzypek i architekt królewski A dam Jarzębski. Mówi on o 3 ogrodach: jednym niewielkim, ozdobnym na tyłach zamku i dwóch innych, których katalogi wydał B e r n h a r d i: 1. na Krakowskim Przedmieściu na Skarpie i 2. na Ujazdowie.

O pierwszym ogrodzie czytamy:

Aż tam drzewka cudzoziemskie

Jak u Pana nieziemskie

Pomarańcze, figi rostą

Wyniosłością w górę prostą.

Kasztany z rozmarynami:

Tu nie bywały przed nami.

Cytrony, także oliwne

1) A. v. H a lle r. Bibliotheca Botanica. Tiguri. 1771. V. I, p. 481. 
Kapary, owoce dziwne

Nuż karczochy, kaulirappi ${ }^{1}$ ),

Sałata owoce trapi,

Rzodkiew, cybul, ogurkones

Nie złe są miasto cytrones

Fenoci ${ }^{2}$ ), seleny ${ }^{3}$ ), kardy,

Angury ${ }^{4}$ ), pasternak, gwardy ${ }^{5}$ )

Jako tam nasienia wiele

Znajdziesz tabak, sławne ziele.

$\mathrm{Na}$ Ujazdowie zaś autor zwraca uwagę na drzewa owocowe, zwłaszcza bogate figownie, rozmaryny, również i na kwiaty, sałaty i jarzyny. Widzimy więc, że już za Władysława IV te ogrody były w pełni rozkwitu. Stoi to w rażącej sprzeczności z nieprawdziwą wiadomością powtarzaną przez naszych historyków zielarstwa polskiego, jakoby założycielką ogrodów botanicznych w Warszawie była druga żona Władysława IV a później Jana Kazimierza królowa Maria Ludwika Gonzaga. Wiadomość tę podają zarówno Zofia Stopa-Rybianka w „Przeglądzie Zielarskim“ 1950 nr $1-3$ str. 25, jak czworo autorów (H. Cybulska, H. J anicka, J. Wiszniewski, A. Wy s o cka) w cennym dziele ,Uprawa i zbiór ziół" (1950, str. 3) w pełnym błędów wstępie historycznym, podając nawet ścisłą datę założenia tych ogrodów - rok 1650. To samo głosi prof. J. Muszyński, a także I. Turowska i A. Olesińs k i w "Zarysie zielarstwa“ T. I. (1951) str. 112.

Tymczasem biorąc pod uwagę świadectwo Jarzębskiego, w tym roku, kiedy ogrody te były w pełnym rozkwicie, królowej Marii Ludwiki nie było jeszcze w Polsce, gdyż żyła jeszcze pierwsza żona Władysława IV Cecylia Renata (1611-1644).

Wspomniane ogrody powstały prawdopodobnie jeszcze za Zygmunta III, kiedy przeniesiono stolicę do Warszawy. Stworzyła je potrzeba zaopatrzenia kuchni i apteki królewskiej. Istnieje natomiast wielkie prawdopodobieństwo, że do ich założenia przyczyniła się szwedzka królewna, siostra Zygmunta III Anna Wazówna (1568-1625). Interesowała się 'ona roślinami leczniczymi, umiała nawet przyrządzać lekarstwa i własnym sumptem wydała „Herbarz“ Szymona Syreńskiego (Syrenius z a 1613). Otrzymawszy od brata starostwa Brodnickie (1604) i Golubskie (1611), przebudowała tamtejsze zamki zwłaszcza w Golubiu, gdzie stworzyła wokół rezydencji wspaniały ogród. W r. 1622 Zygmunt podarował jej w Warszawie stare dwory książąt Mazowieckich (na Krakow-

1. Kalarepa, 2. koper włoski, 3. selery, 4. kawony, 5. ogórki wężowe. 
skim Przedmieściu i na Ujazdowie). Władając przez 3 lata przed śmiercią tymi terenami, nie myślała o stworzeniu tam nowoczesnej rezydencji (uczynił to dopiero Jan Kazimierz), gdyż już posiadała urządzone rezydencje w Brodnicy, a zwłaszcza w renesansowym pałacu w Golubiu. Znając jednak jej energię i specjalne zamiłowanie do hodowli roślin, łatwo przypuścić, że wyzyskała te tereny, jakie posiadała w Warszawie, do utworzenia tam ogrodów w myśl życzeń króla Zygmunta.

SPIS ROSLIN $Z$ OKOLIC WARSZAWY PODANYCH PRZEZ MARCINA BERNHARDIEGO W DZIELE „CATALOQUS PLANTARUM QUAE IN HORTIS REGIIS WARSAVIAE ET CIRCA EANDEM IN LOCIS SYLVATICIS, PRATENSIBUS, ARENOSIS ET PALUDOSIS NASCUNTUR COLLECTARUM

(GDANSK 1652)

ENUMERATIO PLANTARUM CIRCA WARSAVIAM CRESCENTIUM EX OPERE. MARTINI BERNHARDI: „CATALOGUS, DANTISCI, 1652“.

Ustilaginea e

Fungi

Ustilago Carbo Tu l. (692, p. 50). U. Hordei (694, p. 50). - U. Avenae (693, p. 50).

Lichenes

Sticta pulmonaria (522, p. 47). - Usnea barbata (426, p. 47).

Musci

Polytrichum commune L. (17, p. 38). - Funaria hygrometrica (18, p. 38).

Pod nazwą Muscus wymieniono następujące gatunki:

„419 Muscus terrestris erectus - 420 Ms. ter. montanus. - 421 M. ter. corniculatus. - 421 M. ter. repens vulgo Lycopodium. - 423. M. saxatilis. - 424. M. cranio humano adnascens. - 425 M. arboreus vulg. s. Lichen arboreum. 426 M. arb. capillaceus. - 427 M. arb. foeniculaceus. - 428 M. arboreus ramosus. - 429. M. arb. crustaceus“. Szereg mchów drzewnych czy skalnych są to porosty, jak np. M. arb. capillaceus - może to być Bryopogon jubatum lub Usnea barbata, M. ter. erectus może być Cladonia rangiferina.

\section{Filicinae}

\section{Pteridophyta}

Ophioglossum vulgatum L. (447, p. 46, 683, p. 50). - Athyrium filix femina (L) R ot h. (249, p. 42). - Aspidium filix mas (248, p. 42). Asplenium trichomanes L. (251, p. 42, 643 , p. 49,644 , p. 49 ). - A. ruta muraria L. (20, p. 38,252, p. $42,558-559$, p. 48$)$, A. adianthum nigrum (17, p. 38,250, p. 42$)$.

Equisetaceae

Equisetum arvense L. (217, p. 42). - E. pratense $\mathrm{Ehrh.}(216$, p. 41). E. silvaticum (219, p. 42). - E. limosum (218, p. 42). - E. palustre L. (218, p. 42), E. hiemale L. (215, p. 41). - E. variegatum S c h 1 . (215, p. 41).

Lycopodiaceae

Lycopodium clavatum L. (422, p. 45). 


\section{G y mosperma e}

\section{Coniferae}

Abies alba Mill. 1, p. 38). - Picae excelsa Link. (2, p. 38). - Juniperus communis L. (353, p. 44).

\section{A ngiosperma e}

Monocotyledones

\section{Alism a t a cea e}

Sagittaria sagittifolia L. (561, 562, 563, p. 48). - Alisma plantago L. (197, p. 41, 493. p. 47). - Al. arcuatum M i ch el (496, p. 47).

Hydrocharitaceae

Hydrocharis morsus ranae L. (439, p. 46).

Juncagin a cea e

Triglochin palustre L. (305, p. 43). - T. maritimum L. (303, p. 43)?

Juncaceae

Juncus bufonius L. (289, p. 43). — J. lamprocarpus E h rh. (302, p. 43).

\section{Liliaceae}

Anthericum ramosum (80, p. 39,482 , p. 46,483 , p. 46$)$. - Allium vineale L. (32: p. 38). - A. ursinum L. (31, p. 38)? A. Victorialis L. (30, p. 38)? Lilum Martagon (367, 368, 369, p. 44). - Polygonatum multiflorum (L) A11. (504, 503, p.47). - P.officinale Al1. (505, p. 47). - Convallaria majalis L. (366, p. 44). - Paris quadrifolia (321, p. 43).

Amary 11 idaceae

Galanthus nivalis L. (432, p. 45).

Ir i d a cea e

Gladiolus imbricatus L. (281, p. 43). - Iris sibirica L. (350, p. 44). I. pseudoacorus L. (351, p. 44).

Gram in ea e

Panicum miliaceum L. (462, p. 46). - Setaria viridis L. (298, p. 43). Milium effusum L. (413, p. 45). - Alopecurus pratensis (L. 35, p. 38, 292, p. 43, 370, p. 44). - Calamagrostis epigeios (L) Rth. (294, p. 43). - Avena elatior L. (293, p. 43. - Phragmites communis Trin. (76, p. 39). - Briza media L. (299, p. 43). - Glyceria fluitans R. B r. (311, p. 43), - G. aquatica W ahl b. (309, p. 43). - Bromus tectorum L. (23, 26, p. 38$)$. - B. arvensis L. $(24,25$, p. 38$)$. - B. secalinus L. (22, p. 38$)$. - Triticum repens L. (290, 297, p. 43). - T. vulgare L. (652, p. 49). - Lolium temulentum L. (377, p. 44). - Secale cereale L. (586, p. 48). - Hordeum distichon L. (333, p. 44). - H. vulgare L. (332, p. 44). - H. murinum L. (334, p. 44). Zea Mays (696, 697, p. 50). -

Orchidaceae

Ophrys muscifera $\mathrm{H}$ uds. (452, p. 46). - Orchis morio L. (457, 467, p. 46). O. coriophorus L. (459, p. 46). - O. latifolius L. (456, p. 46). - O. maculatus L. (458, p. 46). Platanthera bifolia (L) R ch b. (448, p. 46). - Epipactis rubiginosa G a d. (454, 
p. 46). - E. latifolia S w. (455, p. 46). - E. palustris Crantz (454, p. 46). - Spiranthes aulumnalis $\mathrm{Rich}$. (450, p. 46). - Cephalanthera alba C ratz (212, p. 41).-C. longifolia (L.) (F r i t s c h. (213, p. 41). - Listera ovata (L.) R. B r. (451, p. 46).

A racea e

Accrus calamus L. (15. 16, p. 38). - Calla palustris (207, p. 41). - Lemna sp. (362, 363 , p. 44).

\section{Dicotyledones}

\section{Betulace a e}

Betula verrucosa Ehrh. (100, p. 39). - Alnus glutinosa Gärtn. (33, p. 38). - Corylus avellana L. (184, 185, p. 41).

F a g a c e e

Fagus silvatica L. (243, p. 42). - Quercus robur L. (547, p. 48). - Q. sp. (529, p. 47).

S a 1 i cà c e a e

Populus alba L. (510, p. 47). - P. nigra L. (511, p. 47). - Salix fragilis L. (567, p. 48).-

S. caprea L. (546, p. 48). - S. repens L. (560, p. 48). - S. viminalis L. (565, p. 48).

Cann a b a c e a

Humulus lupulus L. (382, p. 45).

Urtic a c a e

Urtica urens L. (686,p. 50) - U. dioica L. (686, p. 50). - Parietaria officinalis L. (466, p. 46).

\section{$\mathrm{U} l \mathrm{~m}$ a c e a e}

Ulmus sp. (681, p. 50).

Polygonacea e

Rumex silvestris Wallr. (360, p. 44). - R. crispus L. (361, p. 44). - R. acetosa L. (11, 12, p. 38). - Polygonum bistorta L. $(101,102,103,104$, p. 40). - P. persicaria L. fl. rubro et albo $(477,476$, p. 47$)$. - P. hydropiper L. (476, p. 47). -

Euphorbiaceae

Mercurialis perennis L. (411, p. 45). - Euphorbia peplus L. (235, p. 42). - E. helioscopia L. (233, p. 42). - E. salicifolia H o st. (230, p. 42). - E. cyparissias L. (232 b, p. 42). - E. esula. L. (232 a, p. 42). - E. virgata W. K. (231, p. 42).

$\mathrm{Bux}$ a c e a e

Buxus sempervirens L. (122, p. 40).

Chenopodiacea e

Chenopodium botrys L. (109, p. 40). - Ch. rubrum L. (85, 87, p. 40). - Ch. bonus He.:ricus L. (107, p. 40). - Ch. ז.). (157, p. 40). - Spinacia oleracea L. (331, p. 44).-Atriplex hortense L. (86, p. 39).

Caryophyllacea e

Dianthus carthusianorum L. (146, p. 40). - D. plumarius L. (145, p. 40). - Vaccaria vaccaria (L.) $\mathrm{H}$ u t. (386, p. 45). - Saponaria officinalis L. (575, p. 48). - Lychnis flos 
cuculi L. (144, 385, p. 40, 45). - Viscaria vulgaris Röhl. (679, p. 50). - Melandryum noctiflorum Fr. (389, p. 45). - M. silvestre Röhl. (384, p. 45, 442, p. 46). - M. pratense Röh l. (383, P. 45, 442, p. 46). - Silene venosa (G 1 i b) A s ch. (388, p. 45) S. otites S m. (599, p. 49). - Holosteum umbellatum L. (41, p. 38). - Stellaria media Vill. (36 b, P. 38), - S. holostea L. (36, b, p. 38). - S. uliginosa M u r r. (42, p. 38, 44, p. 39). - S. palustris Ehrh. (43, p. 39). - Herniaria glabra L. (506, p. 47). Scleranthus annuus L. (507, p. 47). -

Aristolochiacea e

Asarum europaeum L. (77, p. 39). - Aristolochia clematitis (72, p. 39). --

$\mathrm{R}$ an uncula cea e

Caltha palustris L. $(129,130$, p. 40$)$ fl. simpl. et pleno. - Aquilegia vulgaris L. (65, p. 39). - Delphinium consolida L. fl. coerul. et allba (176, 177, 187, p. 41). - Pulsatilla Wolfgangiana Bess. (523, p. 47). - P. pratensis Mill. (524, p. 47). - Hepatica triloba Gilib (320, p. 43). - Ranunculus fluitans L. (533, P. 47). - R. circinnatus $\mathrm{Sibth.}(254$, p. 42$)$. - R. flammula L. (253, p. 42), (531, p. 47). - R. reptans L. (541, p. 48). - R. arvensis L. (538, p. 48). - R. bulbosus L. (534, p. 48). - R. repens L. (542, p. 48). - R. acer L. (530, p. 47). - R. lanuginosus L. (537, p. 48). - R. polyanthemos L. (532, p. 47). - Thalictrum angustifolium L. (560 a, p. 48). - Th. minus L. (560 b, p 48). - Adonis autumnalis L. (21, p. 38). -

Nymphaeaceae

Nymphaea alba L. (437, p. 45). - Nuphar luteum (L.) S : b t h. et S m. (440, p. 46). N. pumilum (T i m m) D C (441, p. 46). -

P a paver a cea e

Papaver argemone L. (68, p. 39). - P. dubium L. (69, p. 39). - P. rhoeas L. (463, 464, p. 46). - Glaucium corniculatum Curt. (465, p. 46). - Chelidonium majus L. (156, p. 40). - Corydalis cava (L.) S chweig g. et Kort (261, p. 42). - Corydalis solida S m. (262, p. 42). - Fumaria officinalis (259, 260, p. 42)).

\section{Cruc iferae}

Cardamine amara L. (133, p. 40). - Dentaria bulbifera (201, p. 41). - Nasturtium officinale R. Br. (223, p. 42).-- N. palustre D C. $(224$, p. 42,349 , p. 44$) .-N$. silvestro R. B r. (224, p. 42), (434, p. 45). - N. amphibium D C. (433, p. 45). - Sisymbrium Sophia L. (617, p. 48). - Alliaria officinalis A ndrz. (29, p. 38). - Erysimum cheiranthoides L.? (229, p. 42, 228, p. 42). - Diplotaxis tenuifolia DC ((607, p. 49). Lunaria rediviva L. (381, p. 45). - Cochlearia armoracia L. (543, p. 48). - Camelina sativa C r. (430, p. 45). - Thlaspi arvense L. (535, 636, p. 49). - Teesdalea nudicaulis R. B r. (637, p. 49). - Lepidium draba L. (121, p. 40). - L. campestre R. B r. (348, p. 44). - Capsella bursa pastoris Mnch. (120, p. 40). - Coronopus procumbens Gil ib. (182, p. 44). - Isatis tinctoria L. (352, p. 44). -

Res ed a ce a e

Reseda luteola L. (222, p. $42 ; 544$, p. 48). -

Cistace a e

Helianthemum obscurum P e r s. $(171,172,173$, p. 41,319, p. 43$)$. - 


\section{Elat in acea e}

Elatine alsinastrum L. (39, p. 38). -

Droseraceae

Drosera rotundifolia L. (550, p. 48).

\section{Violaceae}

Viola odorata L. fl. coer. et albo $(671,672$, p. 50). V. tricolor L. (670, 672, 673, 674, p. 50). - V. arvensis M urr. (675, p. 50). -

Hy pericacea e

Hypericum perforatum L. (339 a, p. 44). - H. humifusum L. (339 b, p. 44). -

Malvaceae

Malva silvestris L. (396, 398, p. 45). - M. borealis W a 11r. (397, p. 45). - M. alcea L. (28, p. 38). - Althaea officinalis L. (45, p. 39). -

Lin a cea e

Linum catharticum L. $(374$, p. 44$)$. - L. perenne L. $(375$, p. 44$)$. - Rodiola linoides G m e 1. (373, p. 44). -

Oxa 1 idacea e

Oxalis acetosella L. (14, p. 38). -

Geraniaceae

Geranium pratense L. (270, 272, p. 42, 43). - G. silvaticum L. (271, p. 42). - G. sanguineum L. (278, p. 43). - G. pusillum Burm. (279, p. 43). - G. columbinum L. (273, p. 43$)$. - G. Robertianum L. (274, p. 43), - Erodium cicutarium L'H érit. (277, 280, p. 43). -

B a ls a min a c e e

Impatiens nolitangere L. (435, p. 45, 90, p. 39). - I. balsamina L. (91, p. 39). -

Rutaceae

Ruta graveolens L. (557, p. 48). -

Polygal a cea e

Polygala vulgaris L. (498, 499, p. 47). - P. amarella C r. (500, p. 47). - P. am. var. austriaca (Cr.) Be c.k. (500, p. 47), -

Anacardiaceae

Rhus coriaria L. (546, p. 48).

A cer a cea e

Acer campestre L. (10, p. 38).-

Celastracea e

Evonymus europaea L. (236, p. 42).

$\mathrm{Rh}$ a m nacea e

Rhamnus cathartica L. (545, P. 48$)$. - R. frangula L. (34, p. 38$)$. - 


\section{Crassulaceae}

Sedum purpureum Schult. (630, p. 49). - S. acre L. $(589,590$, p. 48$)$. - S. maximum S u t. (242, p. 42$)$. Sempervivum tectorum L. (587, p. 48,631, p. 49$)$. - S. soboliferum L. (588, p. 48).

\section{Saxifragaceae}

Saxifraga granulata L. (576, p. 48) - Parnassia palustris L. (308, p. 43).

Ros a cea e

Rosa canina L. (548, 549, p. 48). - Agrimonia eupatoria L. (27, p. 38). - Sanguisorba officinalis L. (485, p. 46). - S. minor S c o p. (486, 487, p. 46). - Filipendula ulmaria M a x. $(680$, p. 50,247 , p. 42). - F. hexapetala G i 1 ib. $(246$, p. 42$)$. - Rubus idaeus L. (554, p. 48). - R. caesius L. (553, p. 48). - R. hirtus W. K. (556, p. 48). - Fragaria vesca L. fructu rubro et albo $(257,258$, p. 42$)$. - Comarum palustre L. $(473$, p. 46$)$. Potentilla alba L. (470, p. 46). - P. recta L. (469, 471, p. 46). P. intermedia L. (472, p. 46). - P. silvestris N e c k. (- P. tormentilla $\mathrm{N} \mathrm{e} \mathrm{c} \mathrm{k),}(474$, p. 46,639 , p. 49). Geum rivale L. (141, p. 40). - G. urbanum L. (140, 142, p, 40). - Sorbus aucuparia. L (618, p. 49). - Prunus acida K. Koch (518, p. 47).

\section{Papilion aceae}

Genista germanica L. (267, 268, p. 42). - G. pilosa L. (445, p. 46). - Cytisus nigricans L. (196, p. 41). - C. ratisbonensis Schaff. $(195$, p. 41). - Ononis hircina J a c q. (444, p. 46). - Melilotus a lbus (M ed) Desr. (356, p. 44, 378, p. 44).-Trifolium arvense L. (359, p. 44, 645, p. 49). - T. agrarium L. (aureum Poll.) (651, p. 49). - T. repens L. (646 a, p. 49). - T. pratense L. (646 b, p. 49). - Anthyllis Ke rneri Sag. (A. Vulneraria L.) (357,358, p. 44, 92, p. 39). - Lotus corniculatos L. (379, p. 44,649 , p. 49). - L. siliquosus L. $(649$, p. 49,380 , p. 44). - Astragalus glycyphyllos L. (164, p. 41). - A. danicus Retz. (84, p. 39). - Onobrychis viciaefolia S cop. (443, p. 46). - Coronilla varia L. (317, p. 43). - Ornithopus perpusillus L. (318, p. 43). - Vicia cassubica L. (67, p. 39). - V. cracca L. (66, p. 39). - V. pisiformis L. (488, p. 46). - Lathyrus silvester L. $(165$, p. 41,24, p. 42,489 , p. 46). Pisum sativum L. (491, p. 46); - P. arvense L. (490, p. 46).

Thy meleacea e

Daphne mezereum L. (198, p. 41). -

Lythraceae

Lythrum salicaria L.

Oenotheraceae

Epilobium angustifolium L. (393, p. 45). - E. hirsutum L. (392, p. 45). - E. parviflorum $\mathrm{S} \mathrm{ch} \mathrm{reb.} \mathrm{(394,} \mathrm{p.} \mathrm{45).} \mathrm{-} \mathrm{E.} \mathrm{collinum} \mathrm{G} \mathrm{m} \mathrm{el.} \mathrm{(395,} \mathrm{p.} \mathrm{45).} \mathrm{-} \mathrm{Trapa} \mathrm{natans} \mathrm{L.}$ (642, p. 49).

\section{Hippuridacea e}

Hippuris vulgaris L. (330, p. 44). -

Cornacea e

Cornus sanguinea L. (181, p. 41). - C. mas L. (180, p. 41). -

Araliaceae

Hedera helix L. (316, p. 43). - 
$\mathrm{U} \mathrm{mbell}$ if er a e

Sanicula europaea L. (573, 574, p. 48). - Eryngium planum L. (227, p. 42). - E. campestre L. (226, p. 42). - Berula angustifolia L. Ko ch. (56, p. 39). - Sium latifolium L. (608, p. 49). - S. Sisarum L. (609, p. 49). - Carum Carvi L. (170, p. 41). Apium graveolens L. (64, p. 39). - Cicuta virosa L. (170, p. 41). - Bupleurum rotundifolium L. (118, p. 40, 475, p. 46). - B. falcatum L. (119, p. 40)? - Petroselinum sativum L. (480, p. 46). - Oenanthe Phellandrium (L.) D C (244, p. 42, 602, p. 49). O. fistulosa L. (245, p. 42). - Seseli annuum L. (601, p. 49). - S. hippomaratrum L. (256, p. 42). - Meum Mutellina L. Gä r tn. (412, p. 45)? Aethusa cynapium L. (168, p. 41). - Foeniculum capillaceum Gilib. (255, p. 42). - Heracleum sibiricum L. (621, p. 49). - H. sphondylium L. (620, p. 42). - Peucedanum Oreoselinum (L.) M n c h. (460, 481, p. 48). - Pastinaca sativa L. (211, p. 41). - Anethum graveolens L. (58, p. 39). - Levisticum officinale L. (364, p. 44). - Angelica silvestris L. (61, p. 39). Archangelica officinalis Hoffm. (60, p. 39). - Daucus Carota L. (199, p. 41, 603, p. 49). - Anthriscus cerefolium Hoffm. (151, p. 40). - A. silvester L. Hoffm. (581, p. 48). - Conium maculatum L. (169, p. 41$)$. -

Pirolacea

Pirola minor L. (528, p. 47). - P. rotundifolia L. (527, p. 47). -

Ericacea e

Vaccinium Myrtillus L. fr. nigro et albo. (231, p. 45). - Calluna vulgaris L. S a 1 is b, (220, 221, p. 42). - Andromeda polifolia L. (551, p. 48).

Primulace a e

Primula officinalis L. Hil1. (512, 513, 514, p. 47). - Samolus Valerandi L. (54, p. 39). - Anagallis arvensis L. (50, p. 39). - A. coerulea Schreb. (51, p. 39). Lysimachia nummularia L. (436, p. 45, 52, p. 39). - L. vulgaris L. (390, p. 45).

Convolvulacea e

Convolvulus arvensis L. $(610,684,685$, p. 49,50$)$. -

Cuscutace a e

Cuscuta europaea L. (188, p. 41).

B orag in a ce a e

Anchusa officinalis L. (57, p. 39, 112, 113, 115, p. 40). - Symphytum officinale L. (624, 625, 627, fl. albo, p. 49). - S. tuberosum L. (626, p. 49). - Pulmonaria obscura D um. (521, p. 47). - P. angustifolia L. (520, p. 47). - Echium vulgare L. (108, p. 40,114 , p. $40,209,210$, p. 41$)$. - Lithospermum officinale L. (376, p. 44). - Cynoglossum officinale L. (194, p. 41). -

Solanaceae

Solanum dulcamara L. fl. albo et violaceo (48, 49, p. 39). - S. nigrum L. (611. p. 49). - Hyoscyamus niger L. (336, p. 44). - Datura stramonium L (623, p. 49).

Scrophulariacea e

Verbascum thapsus L. (661, p. 50). - V. thapsiforme Schrad. (660, p. 50). V. lychnitis L. (662, p. 50). V. nigrum L. (663, p. 50). - V. blattaria L. (105, 106, 
p. 40). - Linaria vulgaris L. 371,372 , p. 44). - Antirrhinum orontium L. (62, p. 39, 585 , p. 48). - Scrophularia nodosa L. (584, p. 48). - Gratiola officinalis L. (313 p. 43). - Veronica beccabunga L. (53, 55, p. 39). - V. chamaedrys L. (38, p. 38). V. teucrium L. $(632$, p. 50$)$. - V. officinalis L. $(633$, p. $49,665,666,667$, p. 50$)$. V. longifolia L. (668, p. 50). - Digitalis purpurea L. (202, 204, p. 41). - D. ambigua L. (203, p. 41). - Melampyrum sp. (404, p. 45). - Euphrasia officinalis L. (239, p. 42).Odontites serotina Lam. (240, p. 42). - Pedicularis palustris L. (467, p. 46). P. sceptrum Carolinum L. (468, p. 46). - Sesamum orientale L. (600, p. 49$)$.

Verbenaceae

Verbena officinalis L. $(664$, p. 50$)$.

Labiatae

Teucrium scordium (509, p. 47, 582, p. 48). - T. montanum L. (634, p. 49)? Marrubium vulgare L. (399, p. 45$)$. - Sideritis montana L. $(605$, p. 49$)$. - Nepeta cataria L. $(127$, p. 40,409 , p. 45). - Glechoma hederacea L. $(314,315$, p. 43). - Brunella vulgaris L. $(515,516,517$, p. 47$)$. - Galeopsis ladanum L. (46, p. 39, 606, p. 49). - G. tetrahit L. (47, p. 39). - Lamium album L. (98, p. 39,689 p. 50). - L. maculatum L. (691, p. 50). - L. purpureum L. (688, p. 50). - Galeobdolon luteum Hu ds. (690, p. 50). - Stachys arvensis L. (664, p. 50). - Betonica officinalis L. (97, 99, p. 39). Leonurus cardiaca L. (134, p. 40). - Ballota nigra L. (400, p. 45). - Salvia pratensis L. (335, p. 44). - S. silvestris, L. (568, p. 48). - Calamintha clinopodium B e n th. (123, p. 40, 174, p. 41). - C. acinos L. Clair. (125, p. 40,175, p. 41). - Hyssopus afficinalis L. 341 , p. 44). - Origanum vulgare L. (461, p. 46). - Thymus serpyllum L. pro p.) Bor b. (593, 595, 597, p. 48). - Th. s. flore albo (594, p. 48). - Th. s. var. citriodora (597, p. 49). - Mentha longifolia L. Huds. - Mentha silvestris L. (410, p. 45). M. aquatica L. (128, p. 40, 401, 408, p. 45). - M. verticillata L. (126, p. 40).

Plantaginaceae

Plantago major L. (492a, p. 46). - P. media L. (492b, p. 46). - P. lanceolata L. (493, 494, p. 47). - P. ramosa (G il i b). A s c her. $(519$, p. 47$)$. -

Gentianaceae

Centaurium umbellatum Gilib. fl. albo et rubro $(149,150$, p. 40). - Gentiana pneumonanthe L. (497, p. 47). -

Asclepiadace a e

Vincetoxicum officinale M $\mathrm{n}$ ch. $(78,79$, p. 39). -

Ole a c a e

Syringa vulgcris L. (628, p. 49). - Ligustrum vulgare L. (365, p. 44). -

$\mathrm{Rubiaceat}$

Asperula tinctoria L. (552, p. 48). - Galium palustre L. $(265,266$, p. 42). - G. aparine L. (63, p. 39).

Caprifoliaceae

Sambucus ebulus L. (208, p. 41). - S. nigra L. (569, 570, p. 48), 70 fol. laciniatis. S. racemosa L. (571, p. 48). - Viburnum opulus L. (572, p. 48$)$. - 
Valerianaceae

Valeriana officinalis L. (656, p. 50$)$. - V. dioica L. $(657,658$, p. 50$)$. -

D i p s a cea e

Dipsacus silvester Huds. (206a, p. 41). - D. pilosus L. (206 b, p. 41). - Succisa pratensis Mnch. (418, p. 45). - Scabiosa ochroleuca L. (579, p. 48). - S. columbaria L. (580, p. 48). - Knautia arvensis Coult. (577, 578, p. 48). -

Cucurbitaceae

Bryonia alba L. (111, p. 40). - B. dioica J a c q. (110, p. 40). -

Campanulace a e

Campanula cervicaria L. (340, p. 44) - C. glomerata L. (131, p. 40). - C. trachelium L. (640, 641, p. 49). - C. rotundifolia L. (132, p. 40).

\section{Compositae}

Eupatorium cannabinum L. (237, 238, p. 42). - Linosyris vulgaris C as s. (83, p. 39$)$. Aster amellus L. (81. p. 39). - Erigeron acer L. (592, p. 48). - Antennaria dioica (L.) G ärtn. (282, 283, 284, p. 43). - Gnaphalium silvaticum L. (285, p. 43, 622, p. 49).Inula helenium L. (214, p. 41). - I. salicina L. (82, 39). - I. Conyza D C (178, 179, p. 41). - Anthemis tinctoria L. $(116,117$, p. 40). - A. arvensis L. $(154$, p. 40). A. cotula L. (153, p. 40). - Achillea millefolium L. (414, 415, 416, p. 45). - A. ptarmica L. (417, p. 45). - Matricaria chamomilla L. (155, p. 40). - Chrysanthemun leucanthemum L. (162, p. 41). - Ch. parthenium L. (Bernh.), (402, 403, p. 45). Ch. segetum L. (163, p. 41). - Tanacetum vulgare L. (629, p. 49). - Artemisia absinthium L. $(4,5 ; 6$, p. 38). - A. vulgaris L. (73, 74, p. 39). - A. campestris L. (75, p. 39). - Tussilago farfara L. (653, 655, p. 49). - Petasites officinalis M n c h. (654, p. 49). - Senecio vulgaris L. (591, p. 48). - S. Jacobaea L. (347, p. 44). - Echinops sphaerocephalus L. (139, p. 40). - Arctium tomentosum Mill. (96, p. 39). - A. lappa L. (94, p. 39. - A. minus Bernh. (95, p. 39). - Carduus nutans L. (137, p. 40). C. acanthoides L. (502, p. 47). - Cirsium lanceolatum S co p. (136, p. 40). - C. acaule (L.) Mill. (9, p. 38). - C. arvense (L.) S co p. (135, 138, p. 40). - Serratula tinctoria L. (598, p. 49). - Onopordon acanthium L. (7, 8, p. 38), (44 b. p. 46). - Centaurea scabiosa L. (346, p. 44). - C. jacea L. (342, 343, p. 44). - C. cyanus L. (189-192, p. 4, 190, fl. albo, 193, p. 4, var. montana L.). - C. austriaca Willd. (-C. phrygia pro p.) (344, p. 44). - Cichorium intybus L. (158, 166, p. 40, 41). - f. flore albo (159, 167, p. 40, 41). - Tragopogon pratensis L. (583, p. 48, 93 a, p. 39). - Scorzonera humilis L. (93 b, p. 39). - Taraxacum officinale L. (200, p. 41). - Picris hieracioides L. (200, p. 41, 484, p. 46). - Chondrilla juncea L. (160, p. 40). - Sonchus oleraceus L. (614, p. 49). - S. asper (L.) H ill. (612, p. 49). - S. arvensis L. (615, p. 49, 322, p. 43). Lactuca scariola L. (355, p. 44, 616, p. 49). - Crepis tectorum L. $(323,325$, p. 43 , 161, p. 41). - C. paludosa L. (325, p. 43). - Hieracium pilosella L. (88, 89, p. 39). H. umbellatum L. $(326,327$, p. 43$)$. -

Oznaczenie dokładne gatunków pierwszej flory zbadanej przez B e r nhardiego przedstawiało niemało trudności. Już Rostafiński zwrócił na to uwagę, że autor ten, drukując 2 katalogi ogrodów królewskich, nie uzgadniał w nich nomenklatury tak, że często jeden i ten sam gatunek figuruje pod różnymi nazwami. To samo można powiedzieć 
$\mathrm{u}$ katalogu okolic Warszawy. B e r $\mathrm{nh}$ a r d i jako pierwszy pionier w tej dziedzinie musiał czerpać $\mathrm{z}$ różnych źródeł, gdzie w owe czasy nomenklatura była bardzo chwiejna, a z polskich źródeł mógł tylko korzystać z Herbarzy Marcina z Urzędowa (1595) i Syreniusza (1613), którzy czerpali z różnych zagranicznych źródeł z nomenklaturą często bałamutną. Dużo nazw roślin katalogu jest oznaczonych jednym wyrazem: czasem jest to nazwa przyjęta dziś za rodzajową, czasem figurująca $w$ nazwie gatunkowej. Nie było trudności $z$ nazwami takimi, które posiadają u nas jeden gatunek, jak Asarum, Hippuris, Alliaria. Tak samo nazwy, jak Botrys lub Ebulus naprowadzały na gatunki Chenopodium botrys i Sambucus ebulus. Lecz taką nazwę, jak Lunaria można interpretować jako Lunaria vulgaris lub paproć Botrychium lunaria. Inne znów wielogatunkowe rodzaje, jak Lolium, Melampyrum, Erysinum nie dadzą się ściśle oznaczyć, tyczy się to zwłaszcza nazw drzew i krzewów, jak Quercus, Betula, Ulmus, Evonymus, które posiadają pod Warszawą po parę gatunków, musimy więc ograniczyć się tylko do podania nazw rodzaju. Czasem jest nazwa przekręcona jak zamiast Chamaeitea wydrukowano Chamaeirea, co idąc za K. Ba uhinem, należałoby uznać za Salix repens, która znów figuruje w innym miejscu pod inną nazwą. Dużo kłopotu sprawiają nazwy Muscus, który figuruje w 10 pozycjach i Gramen - w 22 gatunkach. Przy małych znajomościach ówczesnych roślin zarodnikowych pod nazwą Muscus figurują zarówno Lycopodium, jak liczne porosty i różne gatunki mchów tak lakonicznie określonych, że nie sposób wyłowić z nich ścisłe nazwy gatunkowe. Pod nazwą Gramen figurują nie tylko Gramineae, lecz Juncaceae i Cyperaceae, nie wszystkie więc udało się ściśle oznaczyć. Usunąłem również ze spisu rośliny, o których wiemy, że nie mogą rosnąć w pobliżu Warszawy, np. rośliny górskie, jak Meum, Gentiana verna, Allium alpinum i inne, a także południowe, jak Umbilicus, Arisarum itp. Autor często jeden gatunek rozbija na kilka wedle barwy kwiatów, co często się zdarza w postaci aloinizmu, lub twoızy gatunki, podając cechy tak niewyraźne, jak major, minor, minima, a czasem species prima, altera, które nic nie mówią. Moim zadaniem było dojść w nazwach do największego prawdopodobieństwa. Opuściwszy więc nazwy roślin, które nie mogą rosnąć w okolicach Warszawy i takie których wobec lakoniczności informacji, trudno rozwikłać i uporządkować synonimikę, mogłem stwierdzić pozytywnie zamiast 697 numerów wymienionych u Bernhardieg o tylko 477 gatunków. Liczba ta jest jak na owe czasy i pierwszą florę duża. Pomimo wielu błędów wynikających częściowo nie $z$ winy autora, lecz ze strony ówczesnej botaniki, musimy przyznać B ernhardiem u za wielką zasługę stworzenie po raz pierwszy obszernej flory okolic Warszawy. 
Przy oznaczaniu duże usługi obok wymienionych polskich zielnikarzy oddało mi dzielo Kaspra Ba uhina "Pinax Theatri Botanici“ (Bazylea 1623) oraz tegoż autora „Prodromos Theatri Botanici“ Wyd. II (Bazylea 1672). W spisie w nawiasach stawiałem numery, jakie są u R os tafiński e go, a obok wskazywałem stronicę.

\section{II \\ Wiek XVIII}

Drugą florę okolic Warszawy opracował w r. 1730 lekarz nadworny Augusta II dr Ernd tel (Ernd tl, Ernd te li u s) (1670-1734). Wydal on w Dreźnie obszerne dzieło pt. Warsavia physice illustrata sive de aere, aquis, locis et incolis Warsaviae, eorundemque moribus et morbis tractatus, cui annexum est Viridarium et Catalogus plantarum circa Warsaviam nascentium (str. 274-332) (Fizyografia Warszawy, czyli o powietrzu, wodach, dzielnicach i mieszkańcach Warszawy, o ich obyczajach i chorobach, do czego został dodany Katalog roślin koło Warszawy rosnących (Viridarium ${ }^{1}$ ).

Erndtel kształcił się na uniwersytecie w Lipsku. Rozprawę doktorską pt. Ex veneno salus ( $\mathrm{Z}$ trucizny zdrowie) wydał w r. $1691 \mathrm{w}$ Giessen. Interesował się medycyną wschodnią. Korzystając $\mathrm{z}$ pracy polskiego misjonarza i podróżnika do Chin ze Lwowa M a r cin a B o y m a wydał dwie rozprawki w tym kierunku. 1. De usu historiae naturalis exotico-geographicae in medicina (O pożytku historii naturalnej geograficznie egzotycznej w medycynie, Lipsk 1700) oraz 2. De flora Japoniensi epistola ac, J. F. Breyne (Listy do J. F. B re y n e' a o florze japońskiej, Drezno 1716).

W latach 1706-7 odbył podróż naukową do Holandii i Anglii, zwiedzając uniwersytety, muzea, szpitale, zaznajamiając się z literaturą naukową. Sprawozdanie $\mathrm{z}$ tej podróży w formie listu do przyjaciela wyszło w 2 wydaniach w Lipsku (1710) i w Amsterdamie (1711). De itinere suo anglico et batavo annis 1706 et 1707 facto relatio ad amicum (O podróży swej do Anglii i Holandii odbytej w latach 1706 i 1707 sprawozdanie dla przyjaciela). Zostawszy w r. 1710 lekarzem nadwornym króla Augusta II, E r n dtel mieszkał dłuższy czas w Warszawie, co mu pozwoliło zebrać liczne obserwacje dotyczące stolicy Polski i utrwalić je w wyżej wymienionym dziele. Autor opisuje dość szczegółowo położenie i rozmiary Warszawy, jej dzielnice, wylicza kościoły, klasztory, szpitale, pałace i ogrody magnatów. Poświęciwszy następnie szereg stron wykładowi o powietrzu jego ciśnieniu i znaczeniu barometru w historycznym rozwoju pojęć, wylicza skamieniało-

1) Patrz: Polski Słownik Biograficzny P.A.U. T. VI. Kraków 1948, str. 289-290. 


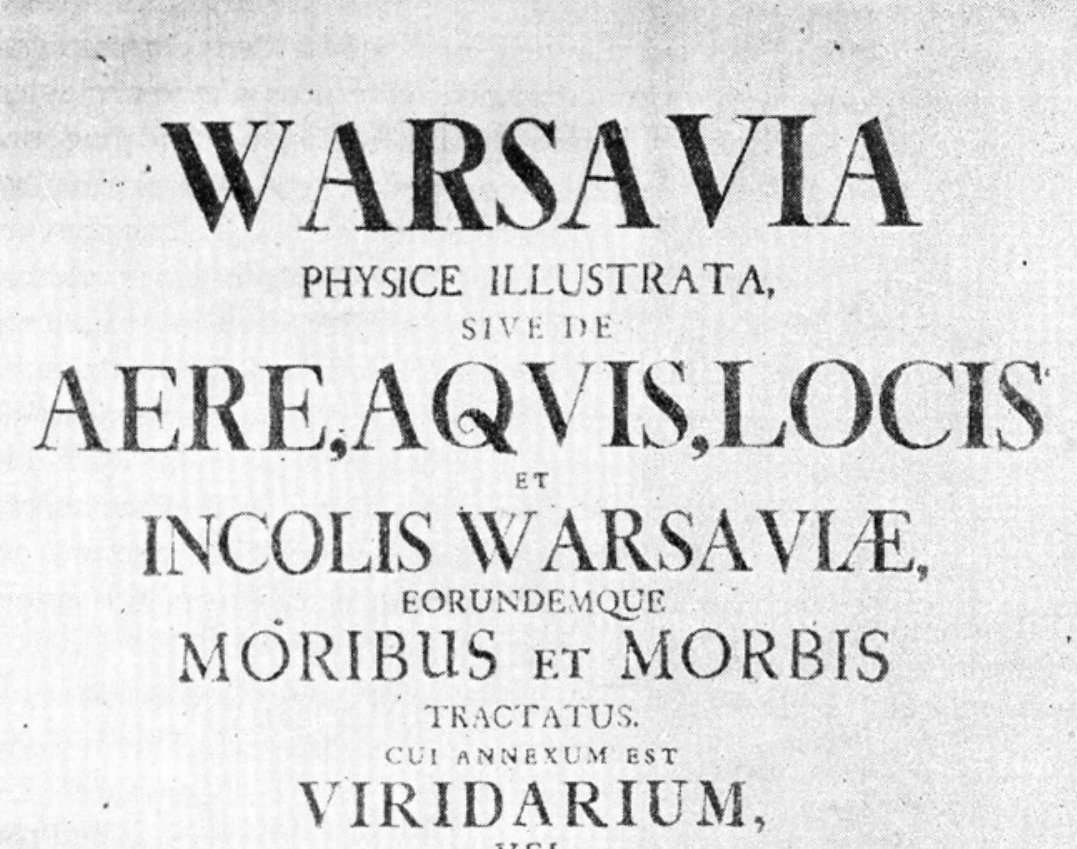

VEL

CATALOGUS PLANTARUM

CIRCA WARSAVIAM NASCENTIUM.

AIITORE

Christiano Henrico ERNDTElio.

PHIL, ET MEDIC. DOCTORE.

SAC. REGIIE MAI. POLON. ET EIECTOR. SAXON. ARCHISTRO.

ET NAT. CURIOS GERMANI/E COLLEGA.

\section{DRESD E .}

spud JOH. CHRISTOPH. ZIMMERMANNI H/ERED. \& IOH NICOL. GERLACHIUM. M DCC XXX.

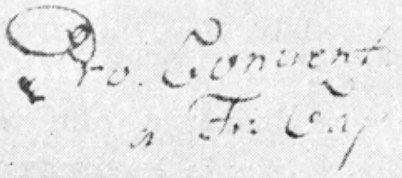

Rys. 3 
ści, iakie zostały znalezione przez dr J. H. H e u c h e r a nad brzegami Wisły w okolicach Warszawy i umieszczone w muzeum w Dreźnie. Wobec tego, że paleontologia w owe czasy stawiała dopiero pierwsze kroki i nomenklatura nie była wyrobiona, spis ten niewiele nam mówi. Cenne natomiast są jako pierwsze dla Warszawy, systematyczne spostrzeżenia meteorologiczne ciśnienia powietrza, kierunku wiatrów i stanu nieba, prowadzone przez 4 lata od r. 1725 do 1728 włącznie. Autor podaje również analizy wód i studzien Warszawy, mówi o mieszkańcach, ich obyczajach, odżywianiu się, o przyrządzaniu pewnych potraw i napojów. Dużo miejsca poświęca autor opisowi chorób grasujących w Warszawie. Uważał on jednak jeszcze kołtun za specjalną chorobę, na którą podawał lekarstwa. W ostatnim rozdziale autor specjalną uwagę poświęca chorobom, jakie obserwował w Warszawie w r. 1720 i sposobom ich leczenia. Poza tym dziełem Erndtel ogłosił drukiem spis roślin zebranych podczas pobytu w miejscowościach kuracyjnych - w Sedlitz koło Drezna i w Cieplicach: 1) Plantarum circa Sedlicenses thermas Elenchus 1723 i 2) De plantis circa thermas theplicenses crescentibus (Acta Acad. nat. cur. t. XIII. 1733).

Ze wstępu; jaki Erndtel napisał do swej flory, dowiadujemy się, $\dot{z}$ e gdy studiował w Lipsku, wiedzę botaniczną zawdzięczał głównie swemu ziomkowi prof. Augustowi Kwirynowi Bachmannowi (1652-1725), znanemu z łacińskich prac naukowych, które pisał pod pseudonimem Rivinus. Był to wszechstronnie wykształcony przyrodnik, jak wielu współczesnych, w jednej osobie medyk, chemik i botanik. Wydał w roku 1690 dzieło pt. ,Introductio generalis in rem herbariam" ze wspaniałymi miedziorytami i podobnie jak $\mathrm{K}$ a s p e r B a u h in zaproponował nazywanie roślin przy pomocy binarnej nomenklatury, dając obok nazwy rodzaju i nazwę gatunku. Tę myśl rozwinął potem Li n ne u s z stosując konsekwentnie tę zasadę do całego państwa roślinnego. Tymczasem $\mathrm{R}$ i v inus, rzuciwszy myśl nową, nie rozwinął jej w swych pracach systematycznych, należąc do tego pokolenia systematyków, którzy idąc za wzorem C e s a l p in a tworzyli sztuczne systemy morfologiczne. R i vin u s oparł swój system na budowie kwiatu zwłaszcza korony, stąd L i n n e u s z zwie go corollista. Ponieważ dokładna budowa kwiatu nie była wówczas dobrze znana, więc i system ów nie znalazł większego uznania. E r n d te l wspomina swego nauczyciela jako tego, który wzbudził w nim zamiłowanie do botaniki i wycieczek terenowych dla zbierania i poznawania roślin. Wspomina również, że poznał także i florę wysokogórską w Alpach Glarneńskich pod kierunkiem J. J. S che u chzera (1672-1733), autora jednej z pierwszych prac paleontologicznych pt. Herbarium diluvianum (1709).

Osiadłszy w Warszawie i zostawszy lekarzem nadwornym króla, 
Erndtel nie mógł już przedsiębrać dalszych podróży, zato skierował swoją pasję zbierania i poznawania roślin na bliższe okolice Warszawy.

Wspomina on na wstępie, że G a l en chwalił bardzo okolice Rzymu jako obfitujące w cenne zioła lecznicze, tymczasem Ernd tel wskazuje, że pod tym względem Warszawa może się poszczycić, że jej flora odznacza się bogactwem ziół leczniczych i klimatem zdrowym nie takim, jak malaryczne okolice Rzymu. Zbierał więc rośliny na polach, łąkach, lasach i bagnach, nie trzymając się utartych dróg i ścieżek, żeby dokładniej poznać dziką florę najbliższych okolic miasta. Nie omieszkał przy tym zapoznać się z ust ludu a częściowo od polskich aptekarzy z polskimi nazwami roślin. Kilkadziesiąt tych nazw umieścił w swojej florze, niestety, w dość skażonej pisowni, opartej na niemieckiej wymowie przy braku niektórych liter, jak $¥$ lub polskie nosówki ą i ę. Te polskie nazwy umieściłem w spisie flory w poprawnej formie. Terenem badań E rnd tla były głównie okolice Marymontu, gdzie stał dawniej pałacyk myśliwski zbudowany przez Sobieskiego dla królowej Marysieńki zwany Mariae mons. Wizerunek tego pałacyku został odtworzony w postaci sztychu w wymienionej pracy. Teren wycieczek autora szedł dalej w okolice klasztoru Kamedułów na Bielanach. Rzeczywiście, trudno było dawniej znaleźć w okolicach Warszawy bardziej urozmaicony pod względem roślinnym teren; dziś roślinność ta jest mocno zniszczona a za czasów Erndtla w pierwszej połowie w. XVIII szata roślinna musiała być bardzo bujna ze względu na charakter terenu. Jeżeli porównać pracę B erṇhardiego z pracą Erndtla musimy przyznać drugiej ogromny postęp. W pierwszej mamy spis roślin często jednym wyrazem oznaczonych, rzadko ze wzmianką barwy kwiatu lub charakterem owoców. U Erndtla jest już nie tylko lista roślin, lecz flora w nowoczesnym znaczeniu tego wyrazu. Większość roślin ma podwójną nazwę rodzaju i gatunku i zazwyczaj krótką diagnozę, autor wszędzie cytuje źródła, opierając się oprócz pracy swego mistrza Rivin u s a na pracach Kaspra Ba u h in a z Bazylei (1550-1624), który już pierwszy zastosował binarną nomenklaturę i uporządkował zawikłaną synonimikę w dziele „Pinax Theatri Botanici“ (I w. 1623, II w. 1671), wraz z dodatkiem ,Prodromus Theatri Botanici, in quo plantae supra sexcentae ab ipso primum descriptae cum plurimis figuris proponuntur" (Bazylea 1671) podobną jak Linne u s z drugiej połowie XVIII w.

Obok tego źródła, najczęściej cytowane są dwa inne poważne źródła: dzieło anglika J o hna R y a (R a jus) (1628-1705) Historia plantarum i francuza J. P. Tourneforta (1656-1708), Institutiones rei herbariae (1700), znamienne przez to, że obaj autorzy dawali już ścisłe określenie rodzajów roślin.

Oprócz tych najważniejszych źródeł autor cytuje wielu innych auto- 


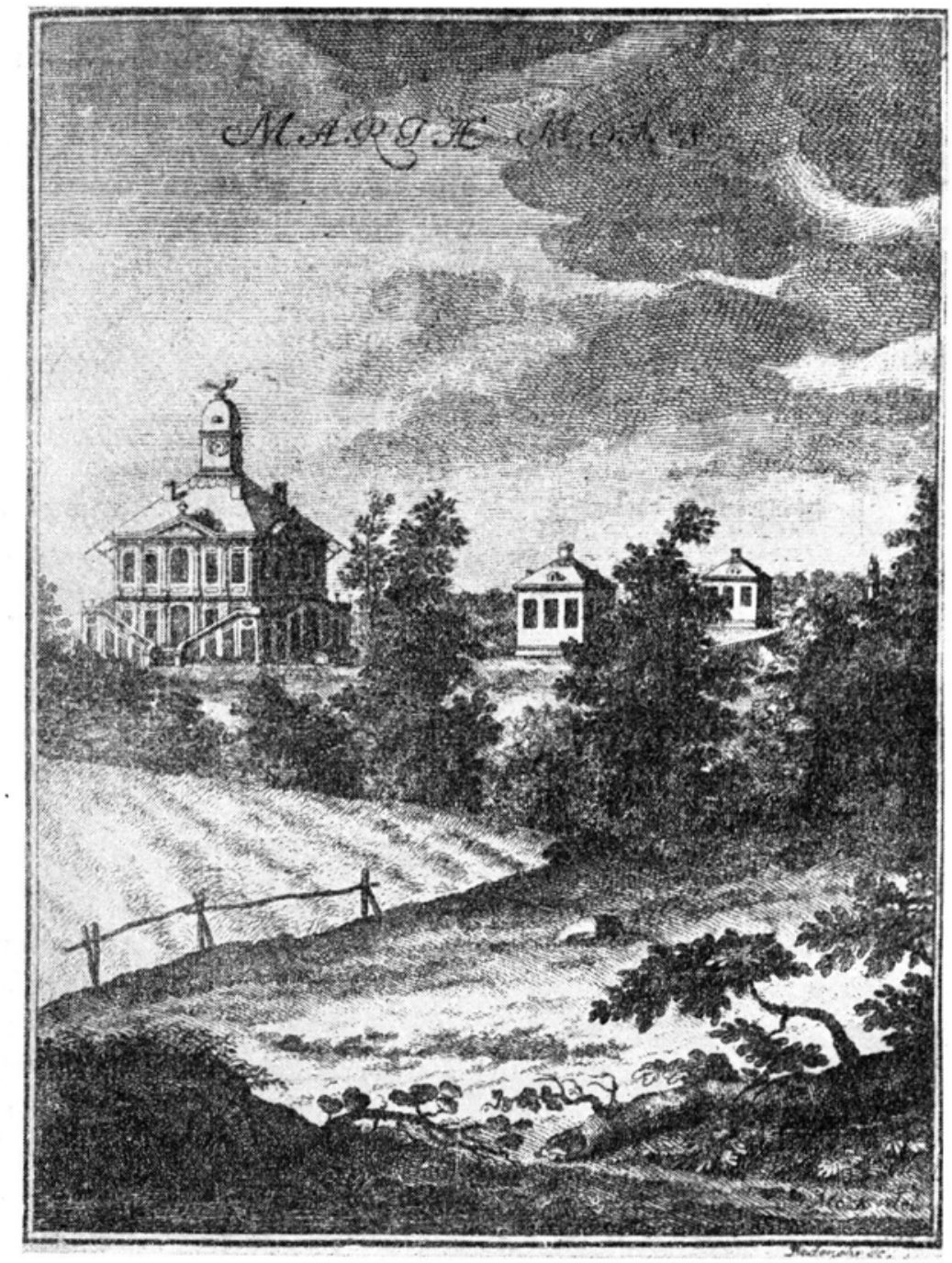

Rys. 4 
rów, sięgając do Teofrasta Dioskorydesa i Pliniusza oraz do zielnikarzy XVI i XVII w., jak Clusius, Lobelius, Dodonaeus, Ruelilius, Johannes Bauhinus, Tabernaemontanus, Matthioli i inni. Przy niektórych gatunkach, mając pewne wątpliwości, autor daje obszerniejsze krytyczne uwagi oparte na dobrej znajomości literatury. Biorąc to pod uwage, musimy przyznać, że mocno krzywdzący te prace jest sąd ks. S. B. Jundziłła, gdy porównywając to dzieło z pracą B ernhardiego pisze, że Erndtel, ,mało co porządniejszy roślinny katalog podał", gdyż praca Bernhardiego jest tylko mało czytelnym katalogiem, podczas gdy praca Erndtla jest już krytyczną florą z opisami roślin, opartymi na najlepszych źródłach owych czasów. Postępern jest zwrócenie uwagi na mało jeszcze zbadane rośliny zarodnikowe, choć wszystkie grzyby (27 gatunków) pomieszcza pod jedną nazwą rodzajową: Fungus, mszaki zaś (31 gatunków) pod nazwą Muscus, choć sa tam nie tylko mchy, lecz widłaki, widliczki i porosty. Słowem praca Erndtla jest już poważnym przyczynkiem do poznania flory okolicy Warszawy.

SPIS ROSLIN OKOLIC WARSZAWY Z DZIELA CHR. H. ERNDTLA ,WARSAVIA PHYSICE ILLU. STRATA“ (1730). ROZDZIAL: VIRIDARIUM WARSAVIENSE (p. 132).

CATALOGUS PLANTARUM CIRCA WARSAVIAM CRESCENTIUM EX OPERE CHR. H. ERNDTELLI (1730). CAPITULUM ,,VIRIDARIUM WARSAVIENSE (p. 1-132).

\section{Fung i}

Erndtel był pierwszym badaczem, który zwrócił uwagę na grzyby kapeluszowe okolic Warszawy. Wszystkie one figurują pod jedną nazwą Fungus. Krótkie określenia łacińskie $\mathrm{i}$ od czasu do czasu zastosowane nazwy polskie pozwalają z dużą dozą prawdopodobieństwa przynajmniej znaczną ich część zdefiniować według nowoczesnej nomenklatury.

Fungus porosus $=$ Morchella conica i M. esculenta. Smardze.

F. orbicularis exalbidus = Tricholoma?

F. Augusti mensis = Boletus edulis Bull.

F. spadiceus $=$ Boletus scaber $\mathrm{B}$ ull.

F. coralliformis = Clavia botrytis Pers.

F. umbilicum referens $=$ Boletus luteis $\mathrm{L}$.

F. angulosus $=$ Lactarius deliciosus L. Rydz.

F. esculentus Clusii XVIII = Lepiota procera Scop.

F. campestris fuscus $=$ Psalliota campestris. Pieczarka.

F. memöranaceus auriculam referens $=$ Auricularia sambucina $\mathrm{M}$ a $\mathrm{r}$.

F. cervinus $=$ Elaphomyces cervinus.

F. penis imaginem referens $=$ Phallus impudicus $\mathrm{L}$. 
F. rotundus orbicularis $=$ Bovista gigantea $\mathrm{Nees}$.

F. muscarius Tragi $=1$. Amanita muscaria 2. Amanita rubescens Fries.

F. muscarius fuscus = Amanita pantherina DC. vel Amanitopsis vaginata Bull.

F. in caudicibus nascens ungulam equinam representans $=$ Polyporus (Fomes) fomentarius et $P$. igniarius.

F. orbiculatus argenteo cinereus = Boletus subtomentosus L.

F. pyxioides seminifer $=$ Peziza sp.

\section{Musci}

Mszaki za czasów E Endtla były jeszcze słabo zbadane. Wiadomośc1 o nich możemy znaleźć w dwóch pozycjach: 1. na str. 9 pod Adianthum aureum majus i A. au. minus; 2. na str. 77-79, gdzie podano 31 gatunków pod ogólną nazwą Muscus. To co podano pod Adianthum, sądząc z opisu i polskiej nazwy, są to dwa pospolite gatunki Polytrichum: P. commune (L.) Br. Eur. i P. piliferum Schreb.

Natomiast pod Muscus podano mieszaninę różnych organizmów. $3 \mathrm{z}$ nich należą do widłaków, a mianowicie: Muscus clavatus foliis cupressi = Lycopodium complanatum L. M. cl. junip. foliis reflexis $=$ L. annotinum L. i $M$. terrestris clavatus $=$ L. clavatum L., toteż umieszczono je w rodzinie widłaków (Lycopodiaceae).

Muscus denticulatus major pulcher repens, sądząc z powołania się na literaturę i rysunki, należałoby uważać za Selaginella helvetica, a $M$. dent. minor za S. selaginoides, lecz podanie tych rośllin $\mathrm{z}$ okolic Warszawy jest nieporozumieniem opartym na błędnym oznaczeniu. Do glonów należą: $M$. aquaticus bombycinus retiformis = = Hyhrodictyon reticulatum, M. aq. denticulatus jest to, prawdopodobnie, Fontinalis antipyretica, natomiast M. ag. tenuissimis foliis caudiculis adhaerentibus = Cladophora sp.

Pod nazwą Muscus mamy tu również trochę porostów (Lichenes). Tak Muscus terrestris erectus i $M$. terr. coralloides erectus cornibus ruffescentibus to Cladonia rangiferina i $\mathrm{Cl}$, rangiformis. $M$. arboreus = Usnea sp., M. cupressiformis ramosus incanus ramulis fere = Stereocaulon paschale?, M. pyxioides = Cladonia pyxidata, M. capillaceus $=$ Bryopogon jubatum.

Natomiast za mchy można uznać: Muscus pennatus major, M. vulgaris pennatus minor. Tu należy, prawdopodobnie, Hypnum crista castrensis lub H. tamariscinun i inne gatunki Hypnum. M. erectus foliis in orbem sparsis = Rhodobryum roseum?, M. capillaceus major stellatus = Mnium hornum. M. terrestris vulgaris minor Adianthi aurei capitulis $=$ Hylocomium splendens, $M$. palustris terrestris similis $=$ Sphagnum palustre (cymbifolium). M. bifolius procumbens foliis subrotundatis $=$ Plagiochila asplenioides.

\section{Pteridophy t a}

Filic in a e

Ophioglossum vulgatum L. -- Aspidium filix mas Sw. - A. thelypteris (L.) Sw. Athyrium filix femina (L.) Roth. - Asplenium trichomnes L. - A. ruta muraria L.

Equisetacea

Equisetum arvense L. - Skrzyp. Koński ogon. - E. silvaticum L. - E. limosum L. E. palustre L. - E. hiemale L. 
Ly copodiacea e

Lycopodium clavatum L. Wroniec, Widłak. - L. annotinum L. - L. complanatum $\mathbf{L}$.

\section{Gy mosperma e}

Coniferae

Abies alba Mill. Jedlina ,non nisi aliquot a Warsavia et praecipue in sylvis Gosenicensibus Oekonomiae Regiae invenitur". Jest to prawdopodobnie stanowisko w Mieni, - Picea excelsa L in k (sub. Abies rubra). Blisko Warszawy nie rośnie, lecz dość obficie z prawej strony Wisły za Pragą. Rosną niektóre okazy w ogrodzie królewskim na Ujazdowie. - Pinus silvestris L. Sosna. Najpospolitsze drzewo koło Warszawy i w całej Polsce. Z drzazeg podstawy pnia wyrabia się łuczywo. - Juniperus communis L. Jałowiec. - J. sabina L. Dużo okazów rośnie w ogrodzie na Ujazdowie. - Thuja occidentalis L. Rośnie w ogrodzie przy klasztorze Reformatów.

Angiospermae

Monocotyledones

Alis mat a c e a

Sagittaria sagittifolia L. - Alisma plantago L.

Butom acea e

Butomus umbellatus $\mathrm{L}$.

Hydrocharitaceae

Hydrocharis morsus ranae L. - Stratiotes aloides L.

$\mathrm{Junc}$ a gin a cea e

Triglochin palustre $\mathrm{L}$.

Potraimogetonaceae

Potamogeton natans L. - P. fluitans L. - P. crispus L. - P. densus L.

J uncace a e

Juncus bufonius L. - J. effusus L. Sit. - J. conglomeratus L. - J. supinus L. J. lamprocarpus $\mathrm{L}$.

Liliacea e

Colchicum autumnale L. Zimowit. - Anthericum ramosum L. - Allium cepa L. Cebula. - A. porrum L. Lug wielki. - A. Schoenoprasum L. - A. sativum L. A. ursinum L. - Gagea lutea K e r. - Lilium martagon L. - Polygonatum multiflorum (L.). A 11. - Majanthemum bifolium (L.) D c. -Convallaria majalis L. Lanka - Asparagus officinalis L. Szparagi. - Paris quadrifolia L.

Ir i d a c a e

Gladiolus paluster L. Mieczyk. - Iris pseudoacorus L. Kosaciec, dziki żółty. t

Cyperacea e

Cyperus fuscus L. - Scirpus lacustris L. Sit. - Eriophorum polystachyum L. E. latifolium H op pe. - Carex cyperoides L. 


\section{Gramineare}

Panicum miliaceum L. - Setaria glauca (L.) P. B. - S. viridis (L.) P. B. S. italica (L.) P. B. Jagle włoskie. - Phalaris arundinacea L. - Anthoxantum odoratum L. - Millium effusum L. - Phleum pratense L. - Alopecurus pratensis L. A. geniculatus L. - A. fulus Sm. - Agrositis spica venti L. - Ag. vulgaris Wirth. - Calamagrostis epigeois (L.) Roth. - C. pseudophragmites (Hall) Baumg. C. lanceolata L. - Holcus lanatus L. - Avena sativa L. Owies. - A. fatua L. A. pubescens Huds. - Phragmites communis Trin. - Briza media L. - Dastylis glomerata L. - Poa annua L. - P. pratensis L. - Glyceria fluitans R. Br. Manna polska. Manna krupiata. - Lolium temulentum L. - Triticum repens L. T. caninum L. - Triticum vulgare Vill. var. hybernum et aestivum. - Secale cereale L. - Hordeum murinum L. - H. distichon L. - H. vulgare L. var. hexastichon. Jęczmień.

Orchidace a e

Cypripedium calceolus L. - Ophrys muscifera Huds. - Orchis militaris L. O. morio L. - O. coriophorus L. - O. incarnatus L. - O.latifolius L. - O. maculatus L. - Gymnadenia conopea R. Br.-Platanthera bifolia (L.) R ch b. - Epipactis rubiginosa Ga ud. - Cephalanthera albo Cratz. - Spiranthes spiralis L. Koch. - Listera ovata (L.) R. B r. - Neottia nidus avis (L.) Rich. -

Sparganiaceae

Sparganium ramosum Court. - S. simplex $\mathrm{H}$ u d s.

Ty phacea e

Typha latifolia L.

A r a cea e

Acorus Calamus L. Tatarskie ziele.-Calla palustris L. - Arum maculatum L.

Le mn a c e e

Lemna minor L.

Dicotyledones

Betulacea e

Betula verrucosa E hr. Brzoza. - Alnus glutinosa Gär t n. Olszyna. - Corylus avellana L. Laskowy orzech.

F a ga cea e

Fagus silvatica L. Buk. - Quercus robur L. Dąb.

I ugland a ce a e

Juglans regia L. Orzech włoski.

S a lic a cea e

Populus alba L. - P. nigra L. - Salix fragilis L. Wierzba. - S. alba L. - S. cinerea L. - S. caprea L. - S. viminalis L. - S. aurita L. - S. repens L. - S. purpurea $\mathrm{L}$.

Moracea e

Morus nigra L. Ogród na Ujazdowie. 


\section{Cannabace ae}

Humulus lupulus L. Chmiel. - Cannabis sativa L. Konopie.

Urticaceae

Urtica urens L. - U. dioica L. - Parietaria officinalis L. Pomurne ziele. Powój. Dzień i noc.

Ulmacea e

Ulmus campestris L. (U. foliacea Gili b).

\section{Loranthaceae}

Viscum album L. Jemioła.

Polygonace a e

Rumex aquaticus L. - R. hydrolapathum Huds. $-R$. sanguineus L. - R. crispus L. $-R$. silvester W a $11 \mathrm{r}$. Kobyli szczaw. $-R$. acetosa L. Szczaw. $-R$. acetosella L. - Polygonum bistorta L. Wężownik. - P. amphibium L. f. aquatica et f. terrestris. - P. persicaria L. - P. hydropiper L. - P. mite $\mathrm{Sch} \mathrm{rank.} \mathrm{-} \mathrm{P.} \mathrm{avicu-}$ lare L. - P. convolvulus L. - Fagopyrum sagittatum Gilib. Tatarczyna.

Euphorbiaceae

Mercurialis perennis L. Szczyr. Merkuriusz. - Euphorbia peplus L. - E. helioscopia L. - E. exigua L. - E. palustris L. - E. cyparissias L. - E. esula L. - E. lathyris L.?

Chenopodiaceae

Beta vulgaris L. var. esculenta et var cicla. Cwikła. - Chenopodium album. L. Ch. rubrum L. - Ch. bonus Henricus L. - Spinacia oleracea L. - Atriplex hastatum L. Łoboda. - Salsola Kali L.

A marantaceae

Amarantus hybridus L.

Caryophyllaceae

Dianthus carthusianorum L. - D. barbatus L. - D. deltoides L. - D. serotinus W. K. - Vaccaria vaccaria (L.) Hut. Saponaria officinalis L. - Cucubalus baccifer L. - Lychnis flos cuculi L. - Viscaria vulgaris Rö hl. - Melandryum silvestre Röhl. - M. pratense Röhl. - Silene venosa (Gijib.) A s ch. - S. otites Sm. S. chlorantha Ehrh.? - Agrostemma githago L. - Arenaria graminifolia S chrad. - Holosteum umbellatum L. - Malachium aquaticum F r. - Sagina procumbens L. - Spergula arvensis L. - Spergularia campestris As c h. - Herniaria glabra L. Żabie gronka. - Sclerathus perennis L. - S. anuus. L.

Aristolochiaceae

Asarum europaeum L. Kopytnik. - Aristolochia clematitis L. Smolnik. W zaroślach wierzby nad brzegiem Wisły.

Berberidaceae

Berberis vulgaris L.

Ranunculaceae

Caltha palustris L. Nogietek. Knieć. - Trollius europaeus L. - Nigella arvensis 
L. - Actaea spicata L. - Aquilegia vulgaris L. - Delphinium consolida L. Clematis vitalba L. - Pulsatilla vernalis Mill. Sasanka. - P. patens Mill. P. pratensis. Mill. - Anemone nemorosa L. - A. ranunculoides L. - Hepatica triloba Gilib. Wątrobnik. - Myosurus minimus L. - Ranunculus fluitans. Lam. Jaskier. Zaba. - R. heterophyllus W e b e r. - R. trichophyllus $\mathrm{C}$ h a i x. - R. lingua L. - R. flammula L. $-R$. sardous $\mathrm{Cranz.}-R$. repens L. $-R$. bulbosus L. $R$. arvensis L. $-R$. auricomus $\mathrm{L}$. $-R$. acer L. $-R$. polyanthemos $\mathrm{L}-\boldsymbol{R}$. Ficaria L. - Thalictrum aquilegifolium L. - Th. angustifolium L. - Adonis aestivalis L.

$\mathrm{Nymph}$ a e a e a e

Nymphaea alba L. Lilia wodna. Grzybienie. - Nuphar luteum (L.) S i b th. et S m.

Ceratophyllaceae

Ceratophyllum submersum L.

Papaveraceae

Papaver argemone L. - P. rhoeas L. - P. sommiferum L. Mak. - Chelidonium majus L. Jaskółcze ziele. - Corydalis cava (L.) S c h w e i g g. et K or t. - C. solida S m. - Fumaria officinalis L. Polna ruta.

\section{Cruciferae}

Cardamine pratensis L. - C. amara L. - Nasturtium officinale R. B r. - N. palustre D C. - Barbarea vulgaris R. B r. - Turritis glabra L. - Sisymbrium Sophia L. Alliaria officinalis Andrz. - Erysimum cheiranthoides L. - Brassica oleracea L. Kapusta. Odmiany: var. capitata alba et rubra (głowiasta biała i czerwona), v. sabauda rugosa (włoska), v. caulorapa (kalarepa, v. gongylodes), v. cauliflora (kalafior, v. botrytis), v. laciniata vel crispa rubra (jarmuż, v. sabellica). - B. napus. Rzepak. - B. campestris L. Rzepa. - Sinapis arvensis L. - S. alba L. - Alyssum calycinum L. - A. hirsutum M. B. - Berteroa incana D C. - Erophila verna D C. Cochlearia armoracia L. Chrzan. - Camelina sativa Cr. - Thlaspi arvense L. T. perfoliatum L. Pępownik. Przerwipęp. - Teesdalea nudicaulis R. Br. - Lepidium sativum L. Rzeżucha. - L. campestre R. Br. - Capsella bursa pastoris Mnch. Taszka. Tobołki. Zanokcica. - Raphanus raphanistrum L. - R. sativus L.

[द. 1

Resedaceae

Reseda lutea $\mathbf{L}$.

C is t a c e e

Helianthemum obscurum Pers.

Elatin aceae

Elatine alsinastrum $\mathrm{L}$.

Droseraceae

Drosera rotundifolia L. Rosiczka.

$\mathrm{V}$ i o l a ce a e

Viola odorata L. et var fl. albo. - V. silvestris (Lam.) R ch b. V. tricolor L. V. arvensis $\mathrm{M}$ urr. 
Guttiferae

Hypericum perforatum L. Panny Marii dzwonki. Sw. Jana ziele. - H. quadrangulum L.

Malvaceae

Malva alcea L. - M. silvestris L. - Althaea officinalis L. Slaz wysoki.

Tili a c a e

Tilia platyphyllos Scop. Lipa. - T. cordata Mill.

Lin a c e e

Linum usitatissimum $\mathrm{L}$. Len.

O xa 1 id a ce a e

Oxalis acetosella $\mathrm{L}$.

Geraniaceae

Geranium pratense L. - G. sanguineum L. - G. columbinum L. - G. Robertianum. L. - Erodium cicutarium L' Herit. Bocianie żurawie noski.

B als a min a ce a e

Impatiens noli tangere $\mathrm{L}$.

Polyg a l a cea e

Polygala vulgaris $\mathrm{L}$.

A c e r a c e a e

Acer pseudoplatanus L. Jawor.

Celastraceae

Evonymus europaea L. - E. verrucosa S c o p.

$\mathrm{Rh}$ a m n a c a e

Rhamnus cathartica L. Szakłak.

Crassulaceae

Sedum maximum Sut. - S. purpureum Schult. - S. acre L. $-S$. boloniense Lois l. - Sempervivum tectorum L.

Saxifragaceae

Saxifraga tridactylites L. - S. granulata L. - Parnassia palustris L. - Chrysosplenium alternifolium L. - Ribes grossularia L.

Ros a cea e

Rosa canina L. - R. spinosissima L. - Alchemilla vulgaris L. Przewodnik. Agrimonia eupatoria L. Rzepik. Starzec. - Sanguisorba officinalis L. - Filipendula ulmaria Max. - F. hexapetala Gilib. - Rubus idaeus L. - R. suberectus A nderson. - R. caesius L .- Fragaria vesca L. Poziomki - Comarum palustre L. Potentilla alba L. $-P$. recta L. $-P$. argentea L $-P$. arenaria Borkh. P. anserina L. Srebrnik. - P. reptans L. Pięciornik. - P. silvestris N e c k. - Geum rivale L. - G. urbanum L. Benedykt. - Crataegus monogyna J a c q. - C. oxyacantha L. - Pirus communis L. Gruszka. - Malus silvestris Mi11. - Sorbus aucuparia L. - Prunus domestica L. Sliwa. - P. cerasus L. - Wiśnia. - P. acida K. K och. - P. padus L. 
Papilionaceae

Genista germanica L. - G. pilosa L. - G. tinctoria L. - Cytisus ruthenicus F is ch. - Ononis hircina J a q. - O.'spinosa L. et f. flore albo. - Medicago falcata L. - Melilotus officinalis (L.) M ed. Nostrzyk. Komonica. - Trifolium arvense L. - T. minus S m. - T. aureum Poll. - T. fragiferum L. - T. repens L. - T. montanum L. - T. rubens L. - T. pratense L. - Anthyllis vulneraria L. Lotus corniculatus L. - Astragalus arenarius L. - Coronilla varia L. - Vicia villosa Roth. - V. sepium L. - V. angustifolia L. - Lathyrus hirsutus L. L. silvester L. - L. pratensis L. - L. montanus Bernh. - L. vernus (L.) Bernh. - L. odoratus L. - Pisum sativum L. Groch. - P. arvense L.

Ty mela e cea e

Daphne mezereum L. Wilcze łyko.

Ly thracea e

Lythrum salicaria $\mathrm{L}$.

Oenotheraceae

Epilobium angustifolium L. - E. Dodonaei Vill. - E. hirsutum L. - Circaea lutetiana L. - C. alpina L.

H a lorrhagidacea e

Myriophyllum spicatum. L

Cornaceae

Cornus sanguinea $\mathrm{L}$.

Araliacea e

Hedera helix L.

$\mathrm{Um}$ belliferae

Sanicula europaea L. - Eryngium campestre L. Mikołajek. - E. planum L. - Berula angustifolia (L.) K o ch. - Sium latifolium L. - Falcaria vulgaris B e r $\mathrm{n}$. Carum carvi L. Hanyż polny. - Aegopodium podagraria L. - Pimpinella major L. Biedrzeniec. - P. saxifraga L. - P. nigra L. - Apium graveolens L. Selery. Cicuta virosa L. - Bupleurum rotundifolium L. - Petroselinum sativum. $\mathrm{H}$ of $\mathrm{f} \mathrm{m}$. Pietruszka. - Oenanthe Phellandrium (L.) D C. - Silaus pratensis B e s s. - Aethusa cynapium L. - Heracleum sphondylim L. Niedźwiedzia. Razdzieniec. Barszcz. Peıcedanum Ostruthium (L.) Koch. Mistrzownik. Dryakiew. Oleśnik swojski. W prywatnych ogrodach. $-P$. palustre $\mathrm{M}$ i c h. $-P$. cervaria $\mathrm{Cu}$ s s. $-P$. oreoselinum (L.) Mnch. - Pastinaca sativa L. Pasternak. - P. opaca Bernh. Anethum graveolens L. Koper. - Levisticum officinale L. Lubczyk. W ogrodach warzywnych. - Angelica silvestris L. - Daucus carota L. Marchew. - Anthriscus cerefolium H of m. Trybula. - A. vulgaris Pers. - Myrrhis odorata (L.) S cop. Popie jajca. - Conium maculatum L. - Coriandrum sativum L. Kolendra. - Chaerophyllum bulbosum L. - Caucalis daucoides L. - Torilis anthriscus (L.) G m.

Pirolaceae

Pirola minor L. - P. media L. - P. rotundifolia L. - P. secunda L. - P. uniflora L. - Chimaphila umbellata (L.) $\mathrm{Nu}$ t t. 


\section{Ericaceae}

Vaccinium Myrtillus L. - V. vitis idaea L. - Oxycoccos quadripetala Gilib. Ledum palustre L. - Calluna vulgaris (L.) S a 1 is b.

Primulaceaie

Primula elatior (L.) Hill. - P. officinalis (L.) Hil1. - Samolus Valerandi L. -.Centunculus minimus L. - Angallis; arvensis L. Myszotrzew. - A. coerulea S chreb. - Lysimachia nummularia L. Pieniążek. - L. vulgaris L. - Trientalis europaea L.

Convolvulaceae

Convolvulus arvensis L. - Volvulus (Calystegia) sepium (L.) Beck.

\section{Cuscutaceae}

Cuscuta europaea L. Konia-przędza

Boragina, cea e

Symphytum officinale L. et var. album. Zywokost. - S. tuberosum L. - Pulmonaria officinalis L. - P. obscura D u m. - P. angustifolia L. - Echium vulgare L. Lithospermum arvense L. Wróble proso. - Myosotis palustris (L.) La m. - M. silvatica Hoffm. - M. stricta L k. Cynoglossum officinale L. Wołowy język. Asperugo procumbens. L.

Sola n a c e a

Hyoscyamus niger L. Szalej. - Solanum nigrum L. - S. dulcamara L. - Datura stramonium L. - Nicotiana tabacum L. Tytoń.

Scriophulariaceae

Verbascum thapsus L. Dziewanna. - V. nigrum L - V. blattaria L. - Linaria vulgaris (L.) Mill. Matki Bożej Len. - Antirrhinum orontium L. Wyżlina. Scrophularia nodosa L. - S. alata Gilib. - Gratiola officinalis L. - Veronica anagallis L. - V. beccabunga L. - V. latifolia L. em. S c o p. - V. chamaedrys L. Ptasie oczka. Ożanka. - V. officinalis L. Przetacznik. - V. prostrata L. - V. teucrium L. - V. spicata L. - V. arvensis L. - V. hederifolia L. - Digitalis purpurea L.? - D. ambigua L. - Melampyrum nemorosum L. - M. cristatum L. Euphrasia coerulea $\mathrm{T}$ a u s ch. - E. officinalis L. - Odontites serotina Lam. Alectorolophus major (Ehrh.) Rehb. - A. minor (Ehrh.) Wimmer et Gr. Pedicularis palustris L. - Lathraea squamaria L. -

Orobanch a cea e

Orobanche caryophyliacea $\mathrm{Sm}$.

Verben a cea e

Verbena officinalis $\mathrm{L}$.

Labia ta e

Teucrium scordium L. - T. scorodonia L. - Scutellaria galericulata L. - S. hastifolia L. - Marrubium vulgare. L .Szanta. - Nepeta cataria L. - Glechoma hederacea L. Kurdybanek. Bluszcz ziemny. - Brunella vulgaris L. Głowienki modre. B. grandiflora Jacq. - Melittis melissophyllum L. - Galeopsis ladanum L. G. speciosa Mi11.-Lamium album L. - L. purpureum L. - L. amplexicaule L. - 
Galeobdolon luteum $\mathrm{Huds}$ - - Stachys palustris L. - S. silvaticus L. - Betonica officinalis L. Bukwica f. flore albo. - Leonurus cardiaca L. Serdecznik. - Ballota nigra L. - Salvia pratensis L. Szałwia. - S. silvestris L. - S. nutans L. - Melissa officinalis L. Melisa. - Calamintha clinopodium Benth. - C. officinalis M o e n ch. - Hyssopus offcinalis L. - Origanum vulgare L. Lebiodka. - O. majorana L. Majeran. - Thymus ovatus Mill. - T. lanuginosus Mill. - T. serpyllum (L. pro p.) B or b. et var. citriodora. - Lycopus europaeus L. - Mentha pulegium L. - M. rotundifolia (L.) H u d s. - M. aquatica L. - M. verticillata L. M. palustris L. - Satureja hortensis L.

Plantaginacea e

Plantago major L. Babka. - P. media L. - P. lanceolata L.

Gentianace a e

Centaurium umbellatum Gilib. Centuria mniejsza.-Gentiana cruciata L.

Men y a $\mathrm{t}$ h a c e a e

Menyanthes trifoliata L. Wodny szczaw. Trzylistki wodne.

A pocynaceae

Vinca minor L.

A s c lepiad a c e a

Vincetoxicum officinale $\mathrm{Mn} \mathrm{ch}$.

Ole a ce a e

Fraxinus excelsior L. Jesion. - Ligustrum vulgare L.

Rub i a cea e

Asperula odorata L. - A. cynanchica L. - Sherardia arvensis L. - Galium cruciata (L.) S c o p. - G. verum L. - G. mollugo L. Marzana. - G. erectum H u d s. G. palustre L. - G. aparine L.

Caprifoliace a e

Sambucus ebulus L. - S. nigra L. - S. racemosa L. - Viburnum lantana L. V. opulus L. - Lonicera xylosteum L.

A d ox a cie a e

Adoxa moschatellina L.

Valerianaceae

Valeriana officinalis L. - V. sambucifolia M i k. - V. dioica L. - Valerianella olitoria (L.) $\mathrm{P} 011$.

D i p s a c e e

Dipsacus silvester $\mathrm{Huds}$. - Succisa pratensis M n ch. - Scabiosa ochroleuca L. Knautia arvensis (L.) C oult.

Cucurbitace a e

Cucurbita pepo L. - Bryonia alba L. - Cucumis sativus L. - C. melo L. 
Campanula ce a e

Phyteuma spicatum L. - Campanula cervicaria L. - C. rapunculoides L. - C. trachelium L. - C. rapunculus L. - C. persicifolia L. - C. rotundifolia L.

Compositae

Eupatorium cannabinum L. - Solidago virga aurea L. - Linosyris vulgaris C a s. Aster amellus L. - Erigeron acer L. - Fuligo germanica L. Kacanki (Kolanki). Antennaria dioica (L.) G ä r t n. - Gnaphalium silvaticum L. - G. uligĩnosum L. Helichrysum arenarium D C. - Inula helenium L. - Pulicaria vulgaris Gä $\mathrm{r} \mathrm{t}$. Płeszne ziele. Płeszcz. - Xanthium strumarium L. - Helianthus tuberosus L. Bidens tripartitus L. - B. cernuus L. - Achillea ptarmica L. Kichawiec. - A. millefolium L. Spływacz. Krwawnik. - Matricaria chamomilla L. Rumianek. - M. inodora L. - Chrysanthemum segetum L. - Ch. leucanthemum L. - Ch. parthenium L. Maruna. - Tanacetum vulgare L. - Artemisia Abrotanum L. - A. absinthium L. Piołun. - Artemisia vulgaris L. Bylica. - Tussilago farfara L. - Petasites spurius (R e tz) R e c h b. - Senecio paluster L. - S. vulgaris L. - S. silvaticus L. S. Jacobaea L. - Carlina vulgaris L. - Carthamus tinctorius L. Szafran polny. Cnicus benedictus L. - Silybum Marianum (L.) Gä r t. - Arctium lappa L. -A. tomentosum Mi11. - Carduus nutans L. - C. acanthoides L. - Cirsium lanceolatum (L.) S c o p. Oset. - C. arvense (L.) S c o p. - Serratula tinctoria L. - Onopordon acanthium L. - Centaurea scabiosa L. - C. cyanus L. Modrak. - C. nigra L. - C. jacea L. - Cichorium Intybus L. Podróżnik. - Lapsana communis L. Hypochoeris radicata L. - Tragopogon pratensis L. - Scorzonera purpurea L. Taraxacum officinale Web. - Sonchus oleraceus L. - S. asper (I.) H ill. S. arvensis L. - Lactuca sativa L. - L. muralis Less. - Crepis praemorsa Ta u s h. - C. tectorum L. - Hieracium pilosella L. Kosmaczek. - H. auricula L.

\section{III}

\section{POCZĄTEK WIEKU XIX}

Autorem trzeciej flory okolic Warszawy, bardziej współczesnej niż poprzednie Bernhardiegoz XVII i Erndtla z XVIII w. był prof. Warszawskiego Uniwersytetu Mich a 1 Szubert (1787-1861) $\left.{ }^{1}\right)$. Nie napisał on właściwie flory, lecz gorliwie zbierając osobiście i przy pomocy swoich uczniów rośliny z okolic Warszawy, włączył je do katalogu roślin rosnących w założonym przez niego (w r. 1818) Warszawskim Ogrodzie Botanicznym. O gorliwości S z u b e r t a świadczy fakt, że katalog przez niego wydany w r. 1824, w 6 lat od założenia Ogrodu, zawiera już 10000 gatunków. Wszystkie stanowiska roślin zebranych w okolicach Warszawy są starannie zanotowane, czasami są podane i ściślejsze wskazówki jak np. okolice Bielan, które dzięki urozmaiceniu konfiguracji terenu były klasyczną miejscowością dla wypraw naszych pierwszych florystów.

1) B. Hryniewiecki. Botanika w Warszawskim Towarzystwie Przyjaciół nauk. - Acta Soc. Bot. Pol. Vol. XX. Suppl. 1951. Str. 1-32. 
W ten sposób z tego katalogu można było wyłowić i skład florystyczny okolic Warszawy.

S z u bert urodzony w Ząbkach pod Warszawą ukończył chlubnie w roku 1808 Warszawskie Liceum. Wydelegowany dla wyższego wykształcenia do Paryża (w r. 1809), był tam uczniem Desfontaines'a, A. W. Jussieu'go i Mirbela i po 4-ch latach pobytu, gdy wrócił

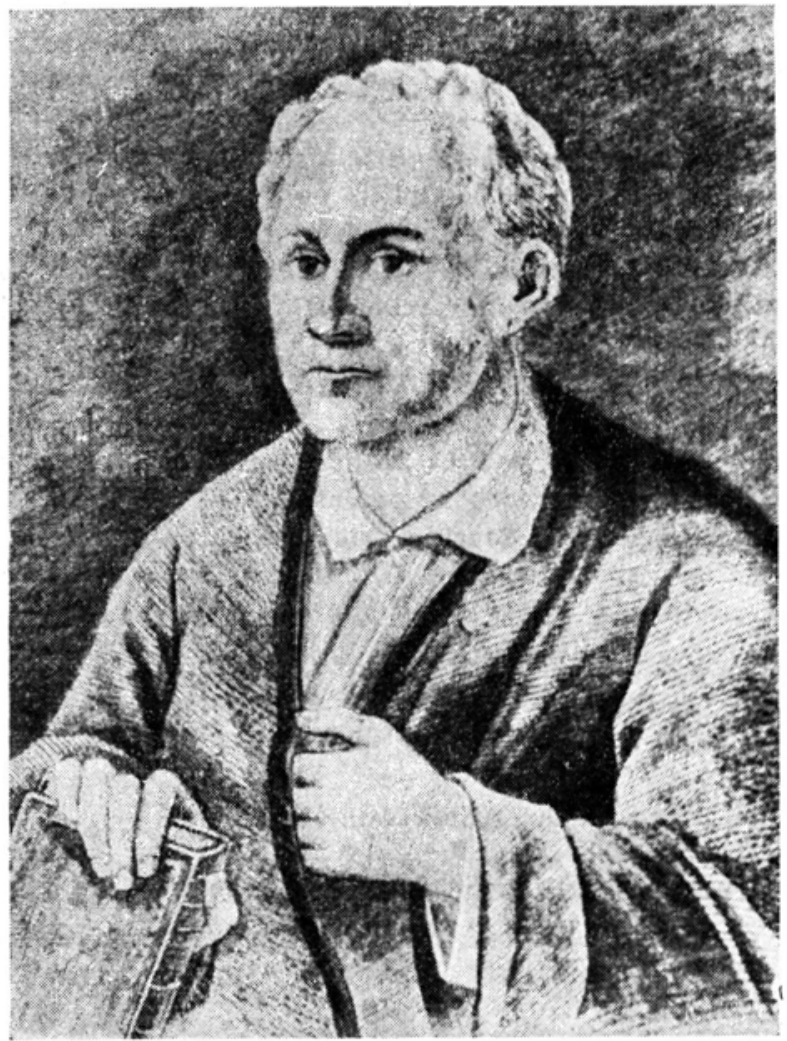

Rys. 5

do Polski, wprowadził w środowisko przesycone dogmatami L i n n e u s z a nowy ożywczy prąd. Przywiózł on ze swoich studiów przekonanie o konieczności wprowadzenia układu naturalnego w studiowanie świata roślinnego, gdyż tylko w ten sposób traktowana systematyka przestaje być nauką bezduszną, czysto formalistyczną, lecz uczy rozpoznawać pokrewieństwo między rodzinami, rodzajami i gatunkami, i prowadzi do zrozumienia ewolucyjnego punktu widzenia w badaniu organizmów. Był on pierwszym pionierem $\mathrm{w}$ Polsce badań anatomii roślin, wydał cenny pod- 
ręcznik drzewoznawstwa - Opisanie drzew i krzewów Królestwa Polskiego (1827), lecz wiekopomną jego zasługą będzie stworzenie i postawienie na wysokim poziomie nowego w Warszawie Ogrodu Botanicznego na terenie przylegającym do Łazienek, który choć mocno okrojony po powstaniu listopadowym, przetrwał do naszych czasów.

W obszernym katalogu wydanym w r. 1824 tkwi również i flora okolic Warszawy. S z u bert nie tylko osobiście zbierał rośliny i przesadzał je do Ogrodu, lecz dzielnie mu pomagali i jego uczniowie: 1) Wojciech J astrzębowski (1799-1882) wówczas adjunkt przy katedrze, później profesor ogrodnictwa i historii naturalnej w Szkole Rolniczo-Leśnej w Marymoncie, wybitny znawca polskiej flory i dzielny krajoznawca, 2) J a k u b W a g a (1800-1872) nauczyciel przyrody giównie w Łomży, późniejszy autor „Flory Polskiej“ (1847/8) i 3) S z y m on P is u le w s k i (1808-1859) późniejszy nauczyciel szkół warszawskich, autor i tłumacz podręczników botanicznych.

Zbierając rośliny w okolicach Warszawy, Sz u bert miał już pomoc w dwóch obszerniejszych florach, jakimi byli: Ks. K. Kluk „Dykcionarz roślinny" w 3-ch tomach (1786-7-8) i 2) W. S. J. G. B ess e r: Primitiae Florae Galiciae Austriacae utriusque. Encheiridion ad excursiones botanicas concinnatus. Pars I. p. 399, pars II, p. 423. Viennae 1809. Obie flory byly ułożone według systemu Linneusza.

$\mathrm{Z}$ B e s s e r e m S z u b e r t był w bliskim kontakcie, jak o tym świadczyła wymiana między nimi listów, z których kilka było w moim posiadaniu, lecz zanim zdążyłem je wydać, zginęły w pogromie Warszawy czasu wojennego. W jednym $\mathrm{z}$ nich $\mathrm{Szubert}$ pisze do $\mathrm{B}$ essera, że po uzyskaniu zezwolenia swoich władz załadowal furę z żywymi roślinami z Ogrodu Botanicznego i wysyła ją do Krzemieńca.

$\mathrm{W}$ innym znów Besser proponuje Szubertowi napisanie wspólnie obszernej polskiej Flory w ten sposób, że Szubert opracowałby tereny zachodnie, B e s s e r zaś wschodnie.

Żałować należy, że tego rodzaju układ nie został zrealizowany. S z ub e r t, aczkolwiek wprowadzając do swego układu system naturalny, wyzwolił się już z powszechnie przyjętego wówczas układu Linn் usza, któremu hołdowali jego poprzednicy - ks. Kluk i W. Besser, lecz cenił bardzo faktyczną stronę flory Bessera. Wprowadziło go to po trosze na manowce synonimiki. Chociaż $\mathrm{Sz}$ u bert na ogół trzymał się dość ściśle ustalonej nomenklatury, dając w swym katalogu nazwę rodzaju, gatunku i skrót nazwiska tego, kto pierwszy opisał gatunek oraz dodając „Index synonimorum“, uderzyło mnie jednak, że przy wielu gatunkach stoi dodatek „Bess“-B esser, chociaż nie były to bynajmniej gatunki opisane przez krzemienieckiego botanika. W tych razach $\mathrm{S} \mathrm{z} \mathrm{u} \mathrm{b} \mathrm{e} \mathrm{r} \mathrm{t}$; 


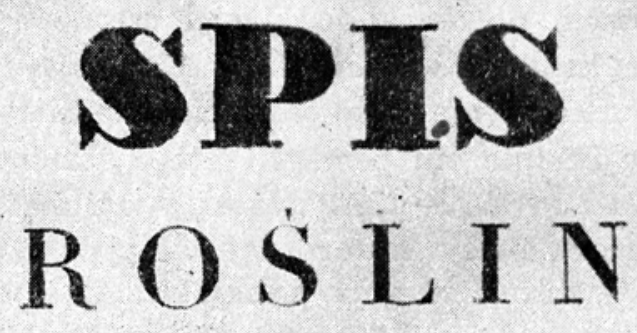

\section{OGRODU BOTANICZNEGO}

SHOLEWSKIEGO : WARSZAWSKIEGO

UNIWFESYPETU.

$$
\text { W Y I A N Y }
$$

PRZEZ M. S Z U B E R T A,

PRORESSORA BOTANLKE, DYREKTURA OGRODU, CZEOAKA TOW. KRÓL. WARSZ. PRZYIACTÓE NAUK:

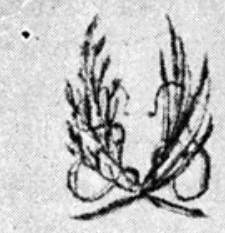

W W ARSZA WIIE, W DRUKARNI SZKOLNEY.

I 8 : 4 . 
tak ścisły w swoich pracach naukowych, popełnia grubą nieścisłość. Chodziło mu widocznie tylko o to, że gatunek podany przez niego jest identyczny z opisem umieszczonym we Florze Bessera, na której się wzorował, lecz nie zrobił żadnego odnośnika, wyjaśniającego ten punkt widzenia. Dlatego też, czyniąc wyciąg z jego Katalogu nie powtarzałem tego błędu, lecz wszędzie stawiałem właściwe nazwisko autora.

Ponieważ flora $\mathrm{Szu}$ berta jest tylko wyciągiem $\mathrm{z}$ katalogu roślin hodowanych w Ogrodzie Botanicznym, przez to jest ona co do ilości gatunków uboższa, niż gdyby jej autor zajął się nią bezpośrednio, gdyż nie wszystkie rośliny z okolic Warszawy znalazły się $\mathrm{w}$ hodowli ogrodowej; w każdym razie spora ich liczba dobrze oznaczona daje już niezłe pojęcie o miejscowej florze.

SPIS ROSI.IN OKOLIC WARSZAWY, ZAWARTYCH W DZIELE M. SZUBERTA „SPIS ROSLIN OGRODU BOTANICZNEGO KROL.-WARSZ. UNIWERSYTETU“. WARSZAWA 1824. ENUMERATIO PLANTARUM A CLAR. M. SZUBERT CIRCA VARSAVIA LECTARUM.

Ch ar a cea e

Chara vulgaris

Ch. hispida

$$
\text { Pteridoph y t a }
$$

Os mund a c e a e

Osmunda regalis $L$.

Ophioglos s a ce ae

Ophioglossum wulgatum, L.

Botrychium lunaria (L.) Sw.

Poly podiace a e

Athyrium Filix femina (L.) Roth. Aspidium thelypteris (L.) Sw.

A. filix mas $S w$.

Asplenium ceterach L.

A. ruta muraria $L$.

Pteridium aquilinum (L.) Kuhn

Polypodium vulgare L.

Hydropteridales

Marsili a c e e

Pilularia globulifera L.

Equisetaceae

Equisetum arvense L.

E. maximum Lam.
E. pratense Ehrh.

E. silvaticum L.

E. limosum L.

E. palustre L.

E. hiemale L.

E. umbrosum?

Lycopodiacea e

Lycopodium clavatum L.

L. complanatum L.

\section{Coniferae}

Abies alba Mill.

Picea excelsa Link.

Larix europaea D C.

Pinus silvestris L.

Juniperus communis L.

Monocotyledones

Alism at a cea e

Sagittaria sagittifolia L.

Alisma plantago L.

Butom a cea e

Butomus umbellatus L.

Hydroch arit a c e e

Hydrocharis morsus ranae $\mathrm{L}$. 
Stratiotes aloides L.

$\mathrm{Junc}$ a g in a ce a e

Triglochin palustre L.

Potamogeton a cea e

Potamogeton natans $\mathbf{L}$.

$P$. perfoliatus L.

$P$. lucens L.

P. gramineus L.

P. crispus L.

P. compressus L.

P. pusillus L.

$P$. densus L.

$\mathrm{Junc}$ a c e a e

Juncus bufonius L.

J. squarrosus L.

J. effusus L.

J. conglomeratus L.

J. glaucus Ehrh.

J. atratus Krocker

$J$. erectus B.

J. uliginosus Smith.

J. bulbosus L.

Luzula pilosa (L.) Willd.

L. multiflora (Ehrh.) Lej.

L. campestris (L.) D C.

Lilia cea e

Anthericum ramosum L.

Allium Scorodoprasum L.

A. vineale $\mathrm{L}$.

A. angulosum $\mathrm{L}$.

A. oleraceum L.

A. carinatum L.

Lilium martagon L.

Gagea lutea Ker.

G. minima Ker.

Ornithogalum umbellatum $\mathbf{L}$.

Majanthemum bifolium (L.) D C.

Polygonatum multiflorum (L.) A.

$P$. officinale All.

Convallaria majalis $\mathrm{L}$.

Paris quadrifolia L.

A maryllidacea e

Galanthus nivalis L.

Irid a ce a e

Gladiolus imbricatus L.
Iris pseudoacorus L.

I. sibirica $\mathrm{L}$.

Cyperacea e

Cyperus fuscus L.

Blysmus compressus, (L.) Panz.

Scripus ovatus Roth.

S. maritimus L.

S. silvaticus L.

S. acicularis L.

S. lacustris L.

S. palustris

S. eupaluster (Ledb.) Rac.

Eriophorum vaginatum L.

E. polystachyum L.

E. latifolium

Carex Davallina Sm.

C. pulicaris $\mathrm{L}$.

C. intermedia Good.

C. vulpina L.

C. divulsa Good.

C. contigua Hoppe (muricata L. pro parte)

C. brizoides $\mathrm{L}$.

C. stellulata Good.

C. elongata L.

C. diandra Schrank (C. teretiuscula Good)

C. paniculata L.

C. paradoxa Willd.

C. caespitosa L.

C. Hudsonii Benn. (C. stricta Good)

C. riparia Curt.

C. digitata L.

C. montana L.

C. praecox Schreb.

C. tomentosa L.

C. flava L.

C. distans $\mathrm{L}$.

C. panicea $\mathrm{L}$.

C. pallescens $\mathrm{L}$.

C. pilosa Scop.

C. Michelii Host.

C. silvatica Huds.

C. pseudocyperus L.

C. lasiocarpa Ehrh. (C. filiformis Good.)

C. acutiformis Ehrh. (C. paludosa Good.)

C. glauca Murr.

C. vesicaria L.

C. hirta L. 
Carex Schreberi Schkuhr..

C. ovalis Good.

C. curta W. E.

C. rivularis Willd.

C. ciliata Willd.

C. Schraderi Schkuhr.

C. ampullacea Willd.

C. ventricosa Curt.

Gram in ea e

Anthoxanthum odoratum L.

Alopecurus pratensis L.

Alopecurus geniculatus L.

Phleum pratense L.

Ph. Boehmeri Wib.

Phalaris arundinacea $\mathrm{L}$.

Panicum (Digitaria) sanguinale L.

P. crus galli L.

Setaria virdis (L.) P. B.

S. verticillata (L.) P. B.

Millium effusum L.

Agrostis canina L.

A. spica venti $\mathrm{L}$.

A. vulgaris With.

A. alba L.

Avena elatior L.

Holcus mollis L.

H. lanatus L.

Hierochloè odorata Whlb.

Catabrosa aquatica P. B.

Aira caespitosa L.

Corynephorus canescens P. B.

Melica nutans L.

Molinia coerulea Mnch.

Dactylis glomerata L.

Cynosurus cristatus L.

Lolium temulentum L.

L. perenne L.

Hordeum murinum L.

Brachypodium pinnatum (L.) P. B.

Br. silvaticum (Huds.) R. et Sch.

Triticum repens $\mathrm{L}$.

T. caninum L.

Bromus mollis L.

$\mathrm{Br}$. arvensis $\mathrm{L}$.

B. sterilis L.

$B$. inermis Leyss.

Festuca pratensis Huds.

F. arundinacea Schreb.
F. ovina L.

F. glauca Lam.

F. rubra $\mathrm{L}$.

F. duriuscula L.

$F$. heterophylla Lam.

F. termifolia Schrad.

F. intermedia R. S (hirsuta Heet)

Poa pratensis $\mathrm{L}$.

$P$. trivialis $\mathrm{L}$.

$P$. nemoralis $\mathrm{L}$.

$P$. compressa $\mathrm{L}$.

$P$. annua $\mathrm{L}$.

P. sudetica Haenke

P. bulbosa L.

Poa palustris L.

Glyceria fluitans R. Br.

Gl. aquatica Whlb.

Briza media L.

Phragmites communis Trin.

Calamagrostis epigeios (L.) Rth.

Calamagrostis lanceolata Rth.

C. arundinacea (L.) Rth.

Koeleria cristata auct.

Nardus stricta L.

Orchid a ce a e

Cypripedium Calceolus L.

Orchis militaris L.

O. morio L.

O. coriophorus L.

O. ustulatus $\mathrm{L}$.

O. maculatus L.

O. sambucinus L.

O. masculus L.

O. latifolius L.

O. pallens L.

Herminium monorchis $\mathrm{R}$. $\mathrm{Br}$.

Platanthera bifolia (L.) Rchb.

Epipactis latifolia All

E. palustris Crantz.

Listera ovata (L.) R. Br.

Neottia nidus avis (L.) Rich.

Sparganiacea e

Sparganium ramosum Court.

S. simplex Huds.

Ty phaceae

Typha latifolia L. 
Typha angustifolia L.

A r a c e e

Acorus calamus L.

Calla palustris L.

L e m n a c a e

Spirodela polyrrhiza (L) Schleid.

Lemna triscula $\mathrm{L}$.

L. minor L.

L. gibba L.

Dicotyledones

Betulace a e

Betula alba L.

Alnus glutinosa Gaertn.

A. incana Moench.

Carpinus betulus L.

Corylus avellana $\mathrm{L}$.

$\mathrm{F}$ a g a c e a e

Fagus silvatica L.

Quercus pedunculata (Q. robur L).

Q. sessilis Ehrh.

$\mathrm{S}$ a li ic a ce a e

Salix pentandra L.

$S$. fragilis $\mathrm{L}$.

S. alba L.

$S$. triandra L.

Salix amygdalina L.

S. caprea L.

S. aurita L.

$S$. viminalis $\mathrm{L}$.

$S$. repens L. $v$. rosmarinifolia Koch

$S$. vitellina L.

S. daphnoides Vill.

S. purpurea L. V. Lambertiana Smith

S. acuminata Patze

S. dasyclados Wimm.

Populus alba L,

P. nigra L.

P. tremula L.

Urticacea e

Urtica urens $\mathrm{L}$.

U. dioica $\mathrm{L}$.

Parietaria officinalis $\mathrm{L}$.

$\mathrm{U} l \mathrm{~m}$ a ce a e

Ulmus campestris L.

U. c. var. suberosa

$U$. effusa Willd.
Loranth a cea e

Viscum album L.

S a n t a la ce a e

Thesium intermedium Schrad.

Polygonace a e

Rumex paluster Sm.

$R$. conglomeratus Murr.

R. hydrolapathum Huds.

$R$. crispus L.

R. maritimus L.

R. obtusifolius Gmel.

R. acutus L.

R. acetosa L.

$R$. acetoscella $\mathrm{L}$.

Polygonum bistorta L.

P. amphibium L.

$P$. persicaria L.

P. hydropiper L.

$P$. minus Huds.

$P$. aviculare $\mathrm{L}$.

P. lapathifolium L.

$P$. incanum Schmidt.

Fagopyrum sagittatum Gilib.

Euphorbiaceae

Mercurialis annua L.

M. perennis L.

Euphorobia helioscopia L.

E. cyparissias L.

E. esula L.

Chenopodiacea e

Chenopodium album $\mathrm{L}$.

Ch. rubrum L.

Ch. murale L.

Ch. urbicum L.

Ch. polyspermum L.

Ch. vulvaria L.

Ch. hybridum L.

Ch. glaucum L.

Ch. bonus Henricus L.

Ch. viride L.

Atriplex patulum L.

A. hastatum L.

A. laciniatum L.

Salsola Kali L. 
A m a r a n t a c e a

Amarantus Blitum L.

Caryophy 11 a cie a e

Dianthus Armeria L.

D. carthusianorum L.

D. deltoides $\mathrm{L}$.

L. serotinus W. K.

D. superbus L.

Gypsophila muralis L.

Vaccaria vaccaria (L.) Ant.

Saponaria officinalis L.

Cucubalus baccifer L.

Lychnis flos cuculi L.

Viscaria vulgaris Röhl.

Melandryum pratense Röhl.

Silene inflata L.

$S$. otites Sm.

S. nutans L.

S. chlorantha Ehrh.

Agrostemma githago L.

Moehringia trinervia $\mathrm{L}$.

Arenaria serpyllifolia L.

Holosteum umbellatum L.

Stellaria nemorum L.

St. palustris Ehrh.

St. graminea L.

St. holostea L.

St. media Vill.

Malachium aquaticum L.

Cerastium arvense $\mathrm{L}$.

C. semidecandrum L.

C. glomeratum Thuill.

C. vulgatum Pers.

Sagina procumbens L.

Spergula arvensis L.

Sagina nodosa Fenzl.

Herniaria glabra L.

H. hirsuta L.

Scleranthus annuus L.

S. perennis $\mathrm{L}$.

Aristolochiaceae

Asarum europaeum L.

Berberidacea e

Berberis vulgaris L.

Ranunculaceae

Caltha palustris L.
Trollius europaeus L.

Isopyrum thalictroides $\mathrm{L}$.

Actaea spicata L.

Cimicifuga foetida L.

Aquilegia vulgaris L.

Delphinium consolida L.

Pulsatilla patens Mill.

P. pratensis Mill.

P. vulgaris W. E.

Anemone nemorosa L.

A. ranunculoides $\mathrm{L}$.

Hepatica triloba Gilib.

Myosurus minimus L.

Ranunculus ficaria L.

R. fluitans Lam.

$R$. hederaceus L.

$R$. lingua L.

R. flammula L.

R. auricomus $\mathrm{L}$.

R. sceleratus L.

R. acer $\mathrm{L}$.

R. repens $\mathrm{L}$.

R. bulbosus L.

$R$. lanuginosus L.

$R$. polyanthemos L.

$R$. gramineus DC.

$R$. nemorosus DC.

Thalictrum aquilegifolium $\mathrm{L}$.

T. minus L.

T. angustifolium L.

T. flavum L.

T. flexuosum Bernh.

Adonis autumnalis L.

$\mathrm{N}$ y m ph a e c e a e

Nymphaea alba L.

Nuphar luteum (L.) Sibth et Sm.

Ceratoph y 11 a cea e

Ceratophyllum demersum L.

Pa paveracea e

Papaver argemone L.

P. rhoeas L.

P. hybridum DC. (hispidum Lam)

Chelidonium majus L.

Fumariaceae

Corydalis cava (L.) Schweigg et Kort

C. solida $\mathrm{Sm}$. 
Fumaria officinalis L.

F. Vaillantii Lois. (parviflora)

Cruciferae

Cardamine pratensis $\mathrm{L}$.

Nasturtium officinale $\mathrm{R}$. Br.

N. palustre DC.

N. silvestre $\mathrm{R}$. $\mathrm{Br}$.

N. amphibium $\mathrm{R}$. Br.

Barbarea vulgaris $\mathrm{R}$. $\mathrm{Br}$.

Turritis glabra L.

Arabis hirsuta Scop.

A. arenosa Scop.

Arabis hirsuta Scop.

Stenophragma Thalianum ᄂel.

Sisymbrium Loeselli L.

Sisymbrium officinale Andrz.

S. sophia L.

S. columnae Jacq.

Alliaria officinalis Andrz.

Sinapis arvensis L.

Brassica nigra Koch.

Alyssum calycinum DC.

Berteroa incana DC.

Erophila verna DC.

Cochlearia armoracia $L$.

Camelina sativa Crantz.

Thlaspi arvense $\mathbf{L}$.

Teesdalea nudicaulis $R$. Br.

Lepidium campestre $R$. B.

$L$. ruderale $L$.

Capsella bursa pastoris Mönch.

Coronopus procumbens Gilib.

Neslea paniculata Desv.

C is t a ceae

Helianthemum obscurum Pers.

Elat in a cea e

Elatine alsinastrum $\mathrm{L}$.

Droseraceae

Drosera rotundifolia L.

Violace a e

Viola odorata L.

V. canina (L. em.) Rchb.

$V$. montana L.

V. tricolor L.

V. arvensis Murr.
Viola arenaria DC.

V. saxatilis Schm.

Guttiferae

Hypericum perforatum L.

H. humifusum L.

H. quadrangulum $\mathrm{L}$.

H. montanum L.

$\mathrm{M}$ a lvace a e

Malva alcea $\mathrm{L}$.

Malva silvestris L.

M. rotundifolia L. prop. (M. borealis Wailt).

M. micrantha $\mathrm{L}$.

Lavatera thuringiaca L.

Tili a cea e

Tilia cordata Mill.

L in a c e a e

Radiola linoides, Gmel.

Linum catharticum L.

Oxalidaceae

Oxalis acetosella L.

Ox. stricta L.

Geraniacea e

Geranium phaeum L.

G. palustre L.

G. pratense $\mathrm{L}$.

G. sanguineum L.

G. pusillum Burm.

G. dissectum L.

G. molle L.

G. silvaticum L. (sub. umbrosum)

G. Robertianum L.

Erodium cicutarium L'Hérit.

Bals a min a cea e

Impatiens nolitangere $\mathrm{L}$.

A cer a c e a

Acer platanoides L.

Acer pseudoplatanus L.

A. campestre L.

Celastracea e

Evonymus europaea L.

E. verrucosa Scop. 
$\mathrm{Rh}$ a $\mathrm{mn}$ a c e a e

Rhamnus cathartica L.

$R h$. frangula $\mathrm{L}$.

Crassulacea e

Sedum acre, L. var. sexangulare

Sedum maximum (L.) Suter

Sempervivum tectorum L.

Saxifragaceae

Saxifraga tridactylites L.

S. granulata $\mathrm{L}$.

Parnassia palustris L.

Chrysosplenium alternifolium L.

Ribes nigrum $\mathrm{L}$.

R. rubrum L.

R. grossularia L.

Ros a cea e

Rosa canina L.

R. dumetorum Thuill.

Alchemilla arvensis (L.) Scop.

A. vulgaris L.

Agrimonia eupatoria L.

Sanguisorba officinalis L.

Filipendula ulmaria Max.

F. hexapetala Gilib.

Rubus saxatilis L.

$R$. idaeus L.

R. caesius L.

R. fruticosus L.

Fragaria vesca L.

Comarum palustre L.

Potentilla alba L.

$P$. supina L.

$P$. norvegica $\mathrm{L}$.

$P$. rupestris $\mathrm{L}$.

$P$. argentea $\mathrm{L}$.

P. rubens Crantz.

$P$. anserina $\mathrm{L}$.

$P$. reptans $\mathrm{L}$.

P. silvestris Neck.

P. Tabernaemontani Aschers.

Geum rivale $\mathrm{L}$.

G. urbanum L.

Crataegus monogyna Jacq.

C. oxyacantha $\mathrm{L}$.

Pirus communis L.

Malus silvestris Mill.

Amelanchier ovalis Med.
Sorbus aucuparia L.

S. torminalis (L.) Crantz

Prunus Padus L.

P. spinosa L.

Papilion a cea e

Genista pilosa L.

G. tinctoria L.

Sarothamnus scoparius (L.) Wimm.

Cytisus nigricans L.

C. ruthenicus Fisch.

C. sessilifolius W. E.

Ononis spinosa L.

Medicag falcata L.

M. lupulina L.

Melilotus officinalis (L.) Med.

M. albus (Med) Desr.

Trifolium arvense $\mathrm{L}$.

T. procumbens L.

T. agrarium $\mathrm{L}$.

T. spadiceum L.

T. fragiferum L.

T. hybridum L.

T. repens $\mathrm{L}$.

T. montanum L.

T. rubens $\mathrm{L}$.

T. alpestre $\mathrm{L}$.

T. pratense L.

T. minus Sm.

Anthyllis vulneraria L.

Lotus ulginosus Schkuhr.

L. corniculatus L.

Astragalus cicer L.

A. arenarius $\mathrm{L}$.

A. arenarius $L$.

Onobrychis sativa Lam.

Coronilla varia L.

Ornithopus perpusillus L.

Vicia hirsuta (L.) S. F. Gray

V. tetrasperma (L.) Mnch.

V. dumetorum L.

V. pisiformis L.

V. silvatica L.

V. cracca L.

V. villosa Roth.

V. sepium L.

V. angustifolia L.

V. sativa L.

Lathyrus silvester L.

L. pratensis L. 
L. tuberosus L.

L. vernus (L.) Bernh.

L. niger (L.) Bernh.

Thy mela e a c a e

Daphne mezereum L.

Ly thraceae

Lythrum salicaria L.

Oenotheraceae

Epilobium angustifolium L.

E. hirsutum L.

E. parviflorum Schreb.

E. palustre L:

E. roseum Schreb.

E. montanum L.

E. adnatum Gris.

Oenothera biennis L.

Circaea lutetiana L.

$\mathrm{Hal}$ orr hagid a cea e

Myriophyllum spicatum L.

M. verticillatum L.

Hippuridaceae

Hippuris vulgaris L.

Callitrichaceae

Callitriche autumnalis $\mathrm{L}$.

C. stagnalis Scop.

Corna ce a e

Cornus sanguinea $\mathrm{L}$.

Araliaceae

Hedera helix L.

U m belliferae

Astrantia major L.

Sanicula europaea L.

Eryngium planum L.

Eryngium campestre L.

Carum carvi L.

Aegopodium podagraria L.

Pimpinella magna $\mathrm{L}$.

$P$. saxifraga $\mathrm{L}$.

P. nigra $\mathrm{L}$.

Cicuta virosa L.

Bupleurum rotundifolium $\mathrm{L}$.

Oenanthe Phellandrium (L.) DC.
Oe. fistulosa L.

Seseli annuum L.

Sium latifolium L.

Berula angustifolia (L.) Koch.

Falcaria Rivini Host.

Aethusa cynapium L.

Heracleum sphondylium L.

Peucedanum palustre Mnch.

$P$. oreoselinum (L.) Mnch.

Pastinaca sativa L.

Angelica silvestris L.

Daucus carota L.

Anthriscus vulgaris Pers.

Conium maculatum L.

Chaerophyllum bulbosum L.

Ch. hirsutum L.

Ch. aromaticum L.

Torilis anthriscus (L.) Gm.

Plumbaginacea

Armeria vulgaris Willd.

Pirolacea e

Pirola minor $\mathrm{L}$.

$P$. secunda L.

$P$. rotundifolia $\mathrm{L}$.

P. uniflora $\mathrm{L}$.

Chimaphila umbellata (L.) Nutt.

Monotropa hypophegea Wallr.

Ericaceae

Vaccinium myrtillus L.

V. uliginosum $\mathrm{L}$.

V. vitis idaea L.

Andromeda polifolia L.

Calluna vulgaris (L.) Salisb.

Oxycoccos quadripetala Gilib.

Primulaceae

Hottonia palustris L.

Primula elatior (L.) Hill.

P. officinalis (L.) Hill.

Anagallis arvensis $\mathrm{L}$.

A. coerulea Schreb.

A. tenella $\mathrm{L}$.

Lysimachia nummularia L.

L. nemorum $\mathrm{L}$.

L. vulgaris L.

L. thyrsiflora $\mathrm{L}$.

Trientalis europaea L. 
Convolvulaceae

Convolvulus arvensis $\mathrm{L}$.

Calystegia sepium L.

$\mathrm{Cuscut}$ a c e a

Cuscuta europaea L.

B or a g in a c e a

Borago officinalis L.

Anchusa officinalis L.

Lycopsis arvensis $\mathrm{L}$.

Pulmonaria officinalis L.

$P$. angustifolia $\mathrm{L}$.

Echium vulgare L.

Myosotis palustris (L.) Lam.

$M$. intermedia Lk.

M. sparsiflora Mik.

M. stricta Lk.

Cynoglossum officinale $\mathrm{L}$.

Omphalodes verna Mönch.

Echinospermum lappula Lehm.

Asperugo procumbens L.

Symphytum officinale L.

Heliotropium europaeum

Lithospermum arvense $\mathrm{L}$.

Solan acea e

Solanum dulcamara L.

S. nigrum L.

Physalis Alkekengi L.

Datura stramonium L.

Hyoscyamus niger L.

Scrophulariaceae

Verbascum thapsus L.

V. nigrum L.

V. blattaria L.

Linaria cymbalaria (L.) Mill.

L. elatine (L.) Mill.

L. spuria (L.) Mill.

L. vulgaris (L.) Mill.

L. minor (L.) Desf.

Antirrhinum orontium L.

Scrophularia nodosa L.

S. alata Gilib.

Gratiola officinalis L.

Limosella aquatica L.

Veronica anagallis $\mathrm{L}$.

$V$. beccabunga $\mathrm{L}$.

V. chamaedrys. L
V. officinalis $\mathrm{L}$.

V. teucrium L.

V. longifolia Baumg.

V. spicata L.

V. arvensis $\mathrm{L}$.

V. verna L.

V. triphyllos L.

V. agrestis $\mathrm{L}$.

Veronica hederifolia L.

V. scutellata L.

Melampyrum cristatum L.

M. arvense $\mathrm{L}$.

M. nemorosum L.

$M$. pratense $\mathrm{L}$.

M. silvaticum L.

Euphrasia officinalis L.

Odontites serotina Lam.

Alectorolophus major (Ehrh.) Rchb..

A. minor (Ehrh.) Wimm. et Grab.

Pedicularis palustris L.

P. silvatica L.

P. sceptrum Carolinum L.

Lathraea squamaria L.

Lentibulariaceae

Utricularia vulgaris $\mathrm{L}$.

$U$. minor L.

Orobanchaceae

Orbanche caryophyllacea Sm.

O. purpurea Jacq.

Verben a c a e

Verbena officinalis $\mathrm{L}$.

L a b i a ta e

Ajuga reptans L.

Ajuga genevensis L.

A. pyramidalis $\mathrm{L}$.

Scutellaria galericulata L.

Sc. hastifolia L.

Marrubium vulgare L.

Nepeta cataria L.

Glechoma hederacea L.

Brunella vulgaris L.

Melittis melissophyllum L.

Galeopsis tetrahit L.

G. pubescens Bess. 
G. speciosa Mill.

G. ladanum L.

Lamium album L.

L. maculatum L.

L. purpureum L.

L. amplexicaule $\mathrm{L}$.

Galeobdolon luteum Huds.

Stachys silvaticus L.

S. palustris L.

$S$. rectus $\mathrm{L}$.

S. annuus L.

Stachys germanicus L.

Sidertis montana L.

Betonica officinalis $\mathrm{L}$.

Leonurus cardiaca $L$.

Chaiturus marrubiastrum (L.) Rchb.

Ballota nigra L.

Salvia pratensis L.

S. dumetorum Andrz.

Calamintha clinopodium Bent.

C. acinos (L.) Clairv.

Origanum vulgare L.

Thymus serpyllum (L. pro p.) Borb.

Th. citriodorus Schreb.

Lycopus europaeus L.

Mentha aquatica $\mathrm{L}$.

$M$. arvensis L.

M. austriaca Jacq.

Plantaginacea e

Plantago major L.

P. media L.

P. lanceolata L.

Ge n t i a n a c e e

Erythraea centarium Pers.

Gentiana cruciata L.

G. pneumonanthe $\mathrm{L}$.

Me $\mathrm{n}$ y a $\mathrm{nt}$ h a c a e

Menyanthes trifoliata L.

A pocynacea e

Vinca minor $\mathrm{L}$.

A s c lepiad a ce a e

Vincetoxicum officinale Mnch.

Ole a c a e

Fraximus excelsior L.
$\mathrm{Rub}$ i a c e a

Sherardia arvensis L.

Asperula odorata L.

Galium boreale L.

G. vernum $\mathrm{L}$.

G. silvaticum L.

G. mollugo L.

G. uliginosum L.

G. palustre L.

G. aparine $\mathrm{L}$.

G. spurium L.

Caprifoliaceae

Sambucus ebulus L.

S. nigra L.

Viburnum opulus L.

Lonicera periclymenum L.

Adoxaceae

Adoxa moschatellina L.

V a.leri a n ce a e

Valeriana officinalis $\mathrm{L}$.

V. dioica L.

Valerianella olitoria (L.) Poll.

$V$. dentata Poll.

D i p s a cea e

Dipsacus silvester Huds.

Succisa pratensis Mnch.

Scabiosa ochroleuca L.

Sc, silvatica

Knautia arvensis (L.) Coult.

Cucurbit a ceae

Bryonia alba L.

$\mathrm{Cam}$ a a u l a c e a

Jasione montana $\mathrm{L}$.

Campanula cervicaria L.

C. glomerata L.

C. rapunculoides $\mathrm{L}$.

C. trachelium L.

C. latifolia L.

C. patula L.

C. persicifolia L.

C. rotundifolia $\mathrm{L}$.

Adenophora liliifolia (L.) Bess.

Composita e

Eupatorium cannabinum L. 
Solidago virga aurea L.

Bellis perennis L.

Erigeron canadensis L.

E. acer $\mathrm{L}$.

Filago germanica L.

$F$. arvensis $\mathrm{L}$.

Antennaria dioica (L.) Gärtn.

Gnaphalium uliginosum L.

G. silvaticum L.

Helichrysum arenarium DC.

Inula helenium $\mathrm{L}$.

I. ensifolia L.

I. salicina $\mathrm{L}$.

I. britannica L.

I. hirta L.

Pulicaria vulgaris Gärtn.

Bidens tripartitus L.

B. cernuus $\mathrm{L}$.

Anthemis tinctoria $\mathrm{L}$.

A. arvensis $\mathrm{L}$.

A. cotula L.

Achillea millefolium L.

A. ptarmica L.

Matricaria chamomilla L.

M. inodora L.

Chrysanthemum leucanthemum $\mathrm{L}$.

Ch. parthenium (L.) Bernh.

Tanacetum vulgare L.

Artemisia absinthium L.

A. vulgaris L.

Tussilago farfara L.

Senecio silvaticus L.

S. vulgaris L.

Senecio viscosus L.

S. vernalis W. K.

S. paludosus L.

S. sarracenicus auct.

S. Jacobaea L.

Calendula arvensis L.

Echinops sphaerocephalus L.

Arctium tomentosum L.

A. lappa (major) Gaertn. L.

A. minus Bernh.

Carduus nutans L.

C. crispus L.

C. acanthoides $\mathrm{L}$.

Carlina acaulis L.

C. vulgaris L.
Cirsium palustre (L.) Scop.

C. canum (L.) MB.

C. oleraceum (L.) Scop.

C. arvense (L.) Scop.

C. lanceolatum (L.) Scop.

C. pannonicum (L.) Gaud.

C. rivuiare (Jacq) Lk.

Serratula tinctoria L.

Onopordon acanthium L.

Centaurea scabiosa L.

C. cyanus $\mathrm{L}$.

C. austriaca Willd.

C. phrygia L.

C. nigra L.

C. jacea L.

Cichorium intybus L.

Scorzonera humilis L.

Leontodon autumnale $\mathrm{L}$.

L. hispidum L.

L. hastile L.

Chondrilla juncea L.

Picris hieracioides L.

Taraxacum officinale Web.

Sonchus oleraceus L.

S. asper (L.) Hill.

$S$. arvensis $\mathrm{L}$.

S. paluster L.

Lactuca scariola L.

L. virosa L.

L. muralis Less.

Crepis tectorum L.

C. biennis $\mathrm{L}$.

C. virens Vill.

C. paludosa Mnch.

Tragopogon pratensis L.

Tr. dubius Scop. (major Jacq.)

Hypochaeris radicata $\mathrm{L}$.

H. maculata L.

Hieracium pilosella L.

H. echioides Lumn.

H. auricula L.

H. murorum L.

H. umbellatum L.

H. cymosum $\mathrm{L}$.

H. dubium Willd.

H. praealtum Vill.

H. glaucescens Bess. 


\section{IV}

BADANIA FLORY I ROSLINNOSCI OKOLIC WARSZAWY W WIEKU XIX I W POEOWIE XX

Rozwój badań florystycznych w okolicach Warszawy w w. XIX i XX, jak i w ogóle w Polsce przeżywał wraz z całym narodem różne okresy czasem zastoju, a czasem bujnego rozkwitu. Możemy tu wyróżnić 5 okresów. 1) Okres I od założenia Towarzystwa Przyjaciół Nauk (1800) i Uniwersytetu Warszawskiego (1816) do likwidacji powstania listopadowego (w r. 1832). 2) Okres II od r. 1832 do założenia Warszawskiej Szkoły Głównej (w r. 1862). 3) Okres III od założenia Warszawskiej Szkoły Głównej (w r. 1862) do końca I wojny światowej (w r. 1918). 4) Okres IV międzywojennej niepodległości (od r. 1918--1939). 5) Okres V od zakończenia drugiej wojny światowej w r. 1945 do czasów obecnych.

Okres I zapoczątkował prof. M. S z u b e r t, zakładając w r. 1818 Warszawski Ogród Botaniczny i wydając w r. 1824 cenny katalog roślin omówiony wyżej. Obok profesora pomagali w opracowywaniu miejscowej flory, jak wyżej wspomniałem, i jego uczniowie, jak Wojciech J a strzębowski, Jakub Waga i Szymon Pisulewski. Pierwszy najwięcej przyczynił się do poznania flory, gdyż zarówno jako student, jak też jako adiunkt Uniwersytetu gorliwie uprawiał florystykę i gromadził zielnik. Te jego zasługi wraz z wynalazkiem tzw. polskiego kompasu były motywem wybrania go na członka przybranego Warszawskiego Towarzystwa Przyjaciół Nauk (w r. 1818), a mianowicie, że ,znalazł w podróży po województwie mazowieckim wiele gatunków roślin, o których botanicy nasi nie wiedzieli“. Wydrukował on w 1829 spis roślin rzadszych, a między innymi znalazł na skraju puszczy Kampinoskiej bardzo rzadki mech - Buxbaumia aphylla.

2

Po likwidacji Uniwersytetu Warszawskiego i Towarzystwa Przyjaciół Nauk po powstaniu listopadowym okres drugi był okresem wielkiego zastoju, który ożywili nieco uczniowie Szubert a - J. W a g a i W. J a$\mathrm{s}$ tr z ę b o w s ki. Pierwszy siedząc na prowincji jako nauczyciel w Łomży wydał w r. 1847-48 Florę Polski, którą oparł głównie na badaniach terenowych północnej części Królestwa Polskiego, lecz są tam i wskazówki o niektórych roślinach z okolic Warszawy. Flora ta w wieku XIX odegrała dużą rolę jako podstawa do badań. J a s tr z ę b o w ski, zostawszy profesorem historii naturalnej i ogrodnictwa w Szkole Rolniczo-leśnej w Ma- 


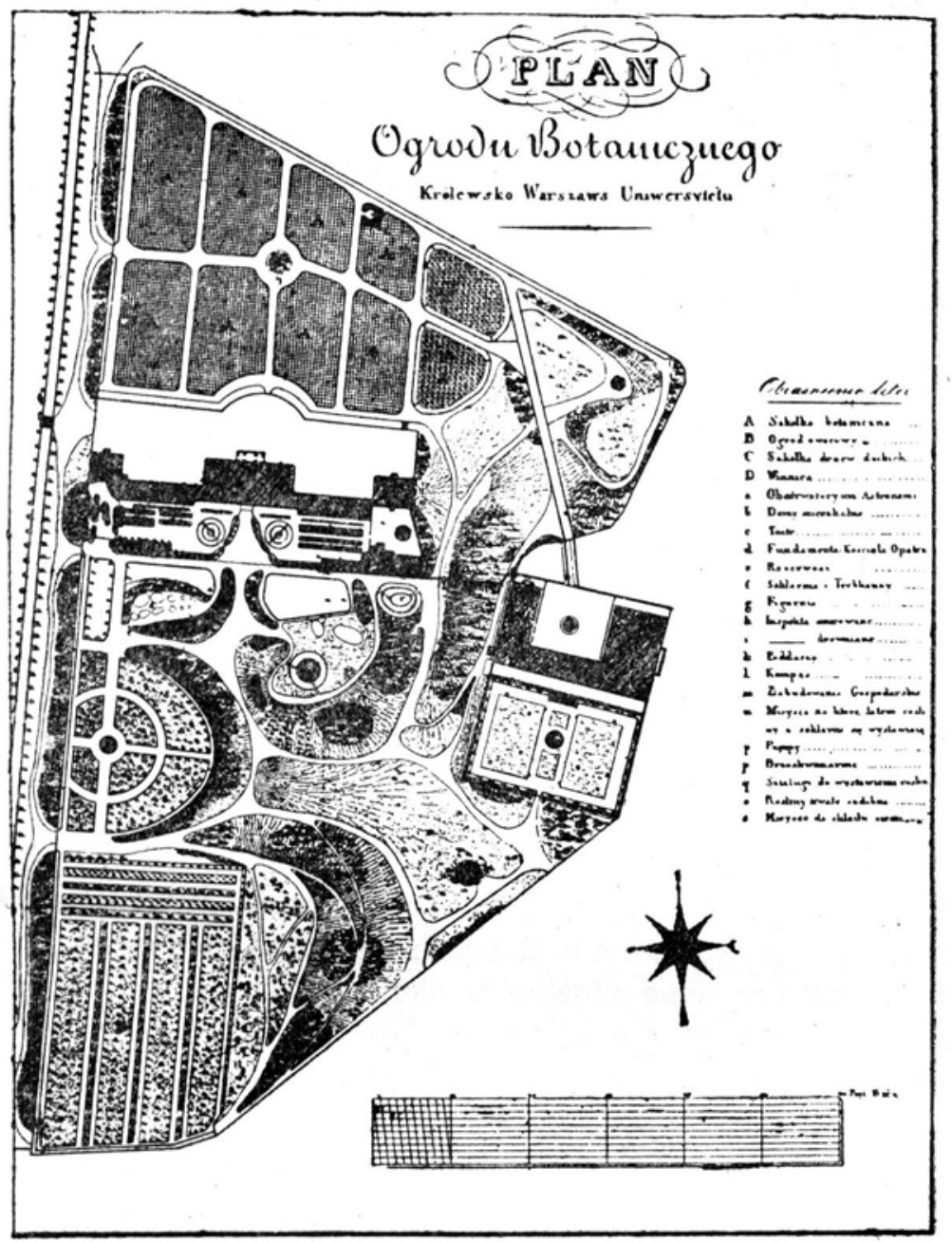

Rys. 7 
rymoncie pod Warszawą, założył tam cenny ogród botaniczny i uprawiał w dalszym ciągu zbieranie roślin w licznych wycieczkach wraz ze swoimi uczniami, chociaż wyników tych badań nie drukował. Gdy podczas powstania 1863 r., mieszkając w leśniczówce pod Brokiem stracił tam w pożarze liczne zbiory, lecz jeden zielnik podarowany Andrzejowi Zamoyskiemu ocalał w Klemensowie i został w następnym okresie wykorzystany przez prof. J. R os tafińskiego.

Można w tym okresie jeszcze zanotować wyjście pracy A. P o ł u jańs ki e g o (1854). Opisanie lasów Królestwa Polskiego. T. I.

\section{3}

W okresie trzecim pomyślnym czynnikiem w zaborze rosyjskim było otwarcie na początku tego okresu w Warszawie Szkoły Głównej, która choć istniała przez czas krótki (1862-1869), jednakże wykształciła niektórych nowych badaczów i dała znów impuls do badań flory okolic stolicy, jak to uczynili dwaj koledzy z tej szkoły F e r d y n a nd Ka ro i J ó z e f R os tafiński, którzy często podejmowali wspólnie bliższe i dalsze wycieczki florystyczne. Pierwszy wynik swych badań ogłosił w Wiedniu (w r. 1867), drugi wydał pierwszorzędną pracę na polu florystyki mianowicie Florae Polonicae Prodromus (1872), która stała się podstawą do dalszych badań na terenie Królestwa Kongresowego. Autor wykorzystał w tej pracy zielnik J a s tr z ę b o w skieg o, gdzie obok własnych spostrzeżeń dużo było stanowisk z okolicy Warszawy tak, że ta praca, zawierająca o 200 gatunków więcej niż Flora J. W a g i, jest nie tylko pracą podstawową dla flory Królestwa Kongresowego, lecz i dla okolic Warszawy. W zielniku Warszawskim są ślady badań florystycznych okolic Warszawy młodocianego studenta a później docenta E d w a r d a S tr a s b u r g e ra, który już będąc profesorem w Jenie odnalazł w okolicach Warszawy ciekawe okazy wątrobowca (Anthoceras laevis) i opisał jego rozwój w polskim wydawnictwie (Wiadomości z nauk przyrodniczych zesz. I. Warszawa. 1880, str. 18-27 z 1 tabl.).

Wychowańcy Szkoły Głównej założyli w r. 1881 Pamiętnik Fizyograficzny, skupiający większość prac florystycznych z terenu zaboru rosyjskiego (wyszło 25 tomów), między innymi i przyczynki do flory okolic Warszawy. W r. 1882 staraniem tego samego grona zaczyna wychodzić Wszechświat, który szerząc wiedzę przyrodniczą, zamieszczał i drobne przyczynki florystyczne. Powstałe w r. 1907 Towarzystwo Naukowe Warszawskie dało również nowe oparcie pracom badawczym. Postęp w badaniu flory w tym okresie polega na tym, że badacze uwzględniali nie tylko rośliny kwiatowe, lecz i zarodnikowe. Sluzowce okolic Warszawy (64 gatunki) badał J. Aleksandrowicz (1872), grzyby opracowali 





F. Błoński, S. Chełchowski, J. Trzebiński, W. Gorjaczkowski i Z. Zweigbaumówna, porosty F. Berdau i K. Filipowicz, glony Kazimierz Cybulski, W. Łopott, W. M. Kozłowski i Ślósarski, mszaki K. Filipowicz, F. Błoński, J. St e in ha u i Sz a f n g e l. O florze kwiatowej obszerniejsze prace ogłosili K. Eapczyński, S. Makowiecki i K. Drymmer. Najcenniejszą jest praca J. T r z e b i ń s.k i e g o „Flora lasów Garwolińskich (1899), gdyż nie jest to tylko katalog roślin, lecz po raz pierwszy zwrócono tu uwagę na ich zespoły. Inni, jak A. Z a lewski F. Kamieński, J. Rostafiński, B. Hryniewiecki, J. Muszyński i Hipolit Cybulski dorzucili do tego krótkie wiadomości o występowaniu poszczególnych gatunków roślin. Szczególniej zasłużył się Hipolit Cybulski starszy ogrodnik Ogrodu Botanicznego, który przez szereg lat prowadził w ogrodzie spostrzeżenia fenologiczne, a od r. 1887 do 1897 ogłosił we Wszechświecie szereg notatek o nowych i rzadkich roślinach okolic Warszawy. Życiorysy zmarłych badaczów z tego okresu podali: J. Rostafiński o W. Jastrzębowskim, A. Z alewski i A. Slósarski o K. Eapczyńskim, M. Raciborski o A. Z alewskim i S. Chełchowskim, M. Załęski i E. Strumpfo J. Wadze, A. Slósarsizi, o F. Berdau, B. Hryniewiecki o F. Błońskim i F. Kamieńskim, J. Aleksandrowicz i ks. J. Wyszyński o M.Szubercie, J. Kowalczyk o Hipolicie Cybuískim, K. Rouppert o F. Kamieńskim.

Gdy przyszła pierwsza wojna światowa, Warszawa szczęśliwie uniknęła bombardowania i zniszczeń. Niemcy, chcąc pozyskać Polaków powołali do życia polski Uniwersytet w Warszawie, wówczas i Ogród Botaniczny pod kierunkiem dyrektora Z. Wóycickiego i inspektora J. Trzebińskiego został uporządkowany, powstał tam dział flory polskiej i stał się na nowo placówką badawczą nad florą okolic stolicy. J. Trze biński ogłosił krótki przewodnik po Ogrodzie (1919) a z racji stuletniego istnienia Ogrodu January Kołodziejczyk ogłosił (w r. 1918) cenną pracę o historii Ogrodu Botanicznego na zasadzie źródeł archiwalnych. W Ogrodzie stanęły 2 pomniki zásłużonych polskich badaczów: założyciela Ogrodu Mi chała Szuberta i autora Flory Polskiej J a uba Wag i. Stacja ochrony roślin przy Warszawskim Towarzystwie Ogrodniczym nie przestawała pracować badając choroby roślin zarówno w okolicach Warszawy, jak i dalszych.

W okresie IV (od r. 1919 do 1939) — niepodległości państwa Polskiego, powstało mnóstwo czynników sprzyjających badaniom botanicznym 
w ugóle a dalszym studiom nad florą okolic Warszawy w szczególności. W r. 1922 powstało Polskie Towarzystwo Botaniczne, które wydało 16 tomów swych prac (Acta) i 5 tomów Bibliotheca Botanica, Towarzystwo Naukowe Warszawskie obok sprawozdań i prac specjalnych zaczęło wydawać „Planta Polonica“, czasopismo poświęcone roślinności Polski i krajów przyległych. Uniwersytet Warszawski przetrwawszy długoletnią fazę rusyfikacji (od 1869 do 1916) stał się uniwersytem polskim. W tym okresie wyszły najważniejsze polskie podręczniki uniwersyteckie. Pomocą dla racjonalnej florystyki stała się książka prof. B. H ryniew ie ckieg o „Zielnik i Muzeum Botaniczne“. Powstała Komisja a później Państwowa Rada Ochrony Przyrody, która zwróciła uwagę na tereny mniej zbadane, co było podnietą do ich zbadania naukowego. Podstawą do badań florystycznych była zainicjowana przez prof. M. Raciborsk i e g o pod redakcją prof. W. Sza f e r a obszerna Flora Polska, wydawana przez Polską Akademię Umiejętności w Krakowie (od 1919 wyszło w tym okresie 6 tomów) oraz Atlas Flory Polskiej (Florae polonicae iconographia) pod red. prof. S. Kulczyńskiego (wyszło 5 zeszytów 1930-36). Zatem w badaniu naszej flory na terenie całej Polski odegrał ważną rolę specjalny dobrze ułożony klucz pt. „Rośliny Polskie“ wydany w r. 1924 przez W. Szafera, S. Kulczyńskiego i B. Pawłowskiego. Podręcznik ten wpłynął na znaczne ożywienie naszej florystyki. Dopełnieniem mu był i prof. J. Ros tafiński e go krótki „Przewodnik do oznaczania roślin dziko rosnących“ (14 wydań), mający tę dobrą stronę, że zawierał 440 starannie wykonanych rysunków roślin. Na Uniwersytecie Warszawskim powstała nowa specjalna katedira systematyki i geografii roślin. Objąwszy w r. 1919 tę katedrę wraz z dyrekcją Ogrodu Botanicznego postawiłem sobie za zadanie doprowadzić Ogród do właściwego porządku, stworzyć nowe kadry badaczów flory i roślinności zarówno kwiatowej, jak i zarodnikowej, wyposażywszy nowy ośrodek pracy w niezbędne pomoce naukowe, jak mikroskopy, książki, okazy muzealne i zielniki. Ze szczupłej dotacji nowego zakładu niewiele można było kupić, lecz udało się wydobyć z różnych zakamarków polskich organizacji w Warszawie dużo cennych pomocy naukowych. Wielkie znaczenie miała biblioteka dr F. Błońskieg o zgromadzona przez tego badacza jakio podstawa do badania flory Polski. Biblioteka za moim staraniem nabyta przez Towarzystwo Naukowe Warszawskie została wtedy przekazana mojej pracowni wraz z niezmiernie cennym zielnikiem, gdzie były nie tylko rośliny zebrane przez Błońskiego, lecz i inne przez niego zakupione, bardzo cenne zielniki z bliskiego Wschodu i z różnych krajów Europy. Tak samo Warszawskie Towarzystwo Ogrodnicze ofiarowało zdeponowane tam zielniki T. Chałubińskiego F. Ber- 
d a u’a i K. Ła p c zyńs ki e g o. Do Zakładu przeszły również zielniki gromadzone w Muzeum Przemysłu i Rolnictwa, jako dowody rzeczowe prac drukowanych w Pamiętniku Fizjograficznym, jak prace D ry m m era, M a j chrowskiego, Eismonda, Kwiecińskiego, Eichlera i innych. Muzeum wzbogaciło się $w$ bezcenną kolekcję ikonograficzną składającą się z 35000 wizerunków roślin egzotycznej flory, przeważnie barwnych, zgromadzonych przez partriarchę Antiocheńskiego ks. Władysława Z a leskiego (1852-1925). Stał on przez czas dłuższy na czele Kościoła Katolickiego w Indiach i kolekcję swą wspaniale ułożoną, opatrzoną cennym katalogiem ofiarował przed śmiercią w Rzymie Uniwersytetowi Warszawskiemu.

Chcąc stworzyć nowe kadry badaczów w dziale systematyki, geografii i ekologii roślin skierowałem wysiłki swoich uczniów na wszystkie te dziedziny, czerpiąc materiał nie tylko z okolic Warszawy, lecz zwracając uwagę na tereny dalsze, jak jez. Wigry, Białowieża, Podole. Zachętą do badań florystycznych był mój artykuł pt. „Praca naukowa na prowincji w dziedzinie botaniki“" (Nauka Polska t. IV.).

Przy opracowaniu roślinności okolic Warszawy zwróciłem uwagę, że chodzi tu nie tyle o zwiększenie katalogu flory, lecz przede wszystkim o zwrócenie uwagi na zespoły roślin według nowszych metod fitosiocjologicznych. W tym duchu powstało kilka prac, jak doskonała monografia R. Kobendzy (Stosunki fitosocjologiczne puszczy Kampinoskiej) i osobno opublikowane w wydawnictwie pod. red. Z. W ó y c i c k i e g o (Krajobrazy roślinne Polski) fotografie zbiorowisk $\mathrm{z}$ tego terenu. W ten sposób zostały opracowane wydmy piaszczyste przez H. J u ras z k ó w$\mathrm{n}$ ę, oraz zespoły torfowisk na prawym brzegu Wisły przez K. K l e i s tó wn ę. Został również opracowany cenny przewodnik florystyczny do wypieczek po okolicach i parkach Warszawy przez R. Kobendzę i J. Koi odziejczyka z przedmową B. Hryniewieckiego o dotychczasowych badaniach florystycznych $w$ tym terenie. $\mathrm{Z}$ punktu widzenia zespołów została opracowana praca W. Niedziałkowskiego o rezerwatach jodiowych pod Łukowem.

Florę okolic Warszawy wzbogaciła „Flora Wilanowa" W. Grochowskiego oraz badania R. Kobendzy, który odnalazł szereg gatunków nowych dla Polski. Chwasty okolic Warszawy z ekologicznego punktu widzenia opracowała M. C zyrsznicówna, znaleziony zaś pod Warszawą nowy chwast - Galinsoga hispida opracowała porównawczo E. M a jd ecka-Z dziarska. O występowaniu epifitów fakultatywnych pisała J. Tworkowska. Z. Dryjówna opracowała statystykę biologiczno-kwiatową flory Polski. Ogólny rzut oka na „Krajobrazy roślinne nad Wisłą" dał J.Kołodziejczyk, który ogłosił również 
szkic popularny „Rys florystyczny okolic Warszawy“ (Ziemia 1922); obszerniej to potraktował później R. Kobendza (1934); jemu też zawdzięczamy opisy fitosocjologiczne niektórych lasów podwarszawskich, jak Bielany, las wawerski, las w Lipkach, modrzewina w Małej Wsi. Ogólny pogląd na lasy okolic Warszawy dali A. Z ę bals ki i B. H r yni ewiecki. Poświęcono też sporo rozpraw oddzielnym drzewom w szeregu prac, jak W. J ed liński (buk, jodła i świerk), B. H ryniewiecki (buk, olsza szara, sosny osobliwych kształtów, lilaki), W. Niedziałkowski (buk, jodła), S. Dziubałtowski (jodła), R. Kobendza (modrzew, brzoza czarna, topole), W. Krzyżi ewi c zówna (jesion); $\mathrm{R}$ ani e ck a przeprowadziła analizę pyłkową interglacjału na Żoliborzu w Warszawie. Zwrócono również uwagę nie tylko na lasy okoliczne, lecz i na zadrzewienie całego miasta ze specjalnym uwzględnieniem parków miejskich. O zadrzewieniu stolicy pisał Edmund Jankowski (1912 i 1934) Opisami parków zajęli się R. K o b e ndza (park Ujazdowski i park im. I. Paderewskiego na Pradze), L. J. K a linowska (Natolin), H. M a j d e cka (ogród Krasińskich), A. Pi etruszyńska (ogród Saski). R. Kobendza badał również zjawiska ekologiczne drzew, jak ,Zawiewanie korzeni sosny przez piasek“ na wydmach okolic Warszawy (1932), „Wpływ zimy 1928-29 na roślinność drzewiastą Ogrodu Botanicznego“ (1933) oraz „Wpływ zimy majowej na roślinność okolic Warszawy“ (1935). S t a n isław W ó yc icki badał wpływ zimy 28-29 roku na drzewa i korę drzew owocowych (1930).

Ogród Botaniczny w ciągu 20 lat niepodległości doszedł do pewnego rozkwitu. W latach 1919-1930 zostały przebudowane wszystkie szklarnie, wszędzie zostało zastosowane centralne ogrzewanie, liczba roślin egzotycznych wzrosła i stan ich znacznie się poprawił. Dla hodowli roślin pod gołym niebem został wyzyskany każdy kącik. Dział drzew i krzewów doszedł do tysiąca gatunków. Botanik-systematyk mógł znaleźć w Ogrodzie wzorową kolekcję okazów reprezentujących najważniejsze rodziny; dział flory polskiej zaznajamiał z najważniejszymi okazami rodzimej roślinności niżowej; dopełniał go dział roślin tatrzańskich i alpejskich w alpinarium. Szkoły mogły tu znaleźć prócz drzew bogaty materiał ilustrujący zarówno morfologiczne, jak i biologiczne cechy roślin. W specjalnych grupach ekologicznych można było obserwować różne zespoły roślinne w miniaturze, jak wrzosowisko, torfowisko, wydmę nadmorską i wydmę lądową utrwaloną, roślinność wodną, roślinność gruntów słonych, wapiennych i stepowych oraz pnącza. Bogata liczba odmian i form doskonale ilustrowała zjawiska zmienności w świecie roślinnym, a nie brak było mieszańców i tzw. chimer roślinnych. 
Szczególną uwagę poświęcono roślinom leczniczym, użytkowym i ozdobnym. Zagadnienie roślin ozdobnych, pomijane najczęściej w ogrodach botanicznych, wskutek czego te ostatnie są nieraz nieciekawe dla przeciętnego widza, rozwiązano $\mathrm{w}$ ten sposób, że poza przeznaczeniem dla nich specjalnej kwatery wszystkie drogi i dróżki otrzymały obramowanie z kolekcji bylin i krzewów ozdobnych, nęcących oko w różnych porach roku pięknością barw i kształtów. Jednocześnie przez porównanie z odpowiednim gatunkiem dzikiej flory, dawały one pojęcie o zmianach zachodzących pod wpływem hodowli. Obok różanki, w której zgromadzono okazy najpiękniejszych róż szlachetnych, była kolekcja róż dzikich wyhodowanych z nasion; obok dzikich tulipanów, irysów, piwonii, złocieni, itp. występowały wytworne i piękne okazy hodowli ogrodniczej. Słowem, uczony i student, nauczyciel i uczeń, leśnik, ogrodnik, farmakognosta, zielarz czy też po prostu miłośnik roślin — każdy mógł w tym żywym muzeum znaleźć dla siebie coś interesującego.

Do pamiątek historycznych przybyła w r. 1928 jeszcze jedna - pomnik w postaci głazu granitowego, poświęconego pamięci pierwszego rektora odrodzonej wszechnicy Józefa Brudzińskiego (1874-1917). Pomnik ten postawili jego koledzy - Polacy, wychowankowie Uniwersytetu Moskiewskiego.

W r. 1932 B. Hryniewiecki wraz z R.Kobendzą wydali obszerny, bogato ilustrowany Przewodnik po Ogrodzie, dopełnieniem jego jest sporządzony przez R. Kobendzę spis drzew i krzewów Ogrodu, obejmujący około tysiąca gatunków.

Ważną sprawą było powstanie przy Ogrodzie pracowni naukowej Zakładu Systematyki i Geografii Roślin, co umożliwia urządzanie wykładów i pokazów w ogrodzie i w szklarniach oraz bezpośrednie czerpanie materiału do ćwiczeń i badań naukowych z tej bogatej skarinicy świata roślinnego. W ten sposób kontakt z Ogrodem młodzieży studiującej i pracującej twórczo w zakresie botaniki stał się niezmiernie bliski. Klęską dla Ogrodu była niezwykle surowa zima roku 1928-29, podczas której zmarzło wiele drzew, np. cisy, między innymi zginęły prastare znane Warszawie lilaki (tzw. „bzy“ pachnące) pamiętające jeszcze czasy S z ub e r t a. Od tego czasu przybyło jednak dużo nowych drzew i krzewów ozdobnych, tak że na miejscu roślin, które śmierć zabrała, pleni się nowe życie.

Wielką bolączką nowego Zakładu była ciasnota pomieszczenia wobec cennych zbiorów jakie zgromadził. Najbardziej reprezentacyjny gmach na terenie Ogrodu został wybudowany dla Obserwatorium Astronomicznego. Poprzedni kierownicy Ogrodu nie dbali o stworzenie na tym terenie muzeum ani większej pracowni. Zakład, wypełniony zbiorami od piwnic 
do poddaszy, gnieździł się w ciasnych pomieszczeniach domku, który dawniej był mieszkaniem ogrodników.

W latach 1930-32 rozgorzała walka o las Wawerski. Był to najpiękniejszy las okolicy Warszawy należący do dóbr Wilanowskich. Właściciele umyślili, wyrąbawszy piękny drzewostan dębowy, rozparcelować go sposobem tzw. „dzikiej“ parcelacji. Ochrona przyrody sprzeciwiła się temu, kołatała do Zarządu Miasta, żeby wziął ten las pod swoją opiekę. Zjawiły się wówczas liczne artykuły pisane przez B. H ryniewieckiego, J. Miklaszewskiego, R. Kobendzę i E. Grabdę, zwoływano specjalne wiece, żeby poruszyć opinię publiczną, niestety, bez skutku. Zgodzono się wreszcie uznać za rezerwat tylko małą cząstkę tego lasu, gdzie rosły zespoły lip wraz z sosną i dębem. Wiadomości o zabytkach przyrody okolic Warszawy opracował M a rian Sokołowski (1933).

Niektóre zjazdy, jakie odbywały się w Wạrszawie były bodźcem do poinformowania przybyłych gości o roślinności okolic Warszawy. Tak powstały przewodniki do wycieczek: B. H r y n i e w i e cki e g o 1) Rzut oka na szatę roślinną Polski i 2) Flora na przestrzeni od Warszawy do Wilna (Kongr. geogr. i etnogr. 1927). 3) Coup d'oeil sur la flore de la P.ologne. 4) Roślinność okolic Warszawy (Varsovie et ses environs) (Wycieczka Międzyn. Fitogeogr. I. P. E. 1928).

W okresie tym nie zaniedbano badań nad roślinami zarodnikowymi. F. Skupi eński badał śluzowce. Wśród badaczów grzybów wyróżniła się A. Skirgi ełłów n a monografią Boletaceae na materiale częściowo zebranym w okolicach Warszawy, A. S z w a n kó wn a badała grzyby wodne (Saprolegniaceae), I. Z y s kó w n a huby drzewne, K. J ankowska - Zewnętrzniaki (Exobasidia) J. G a w in ow a zebrała materiały do cecidiologii Mazowsza, W. Grochowski badał sporysze polskie. Szeroką działalność w badaniu grzybów wywołujących choroby roślin rozwinął prof. $\mathrm{SGGW}$ W. Si emiaszko i jego uczniowie. J. Kochmàn dał monografię głowniowych (Ustilagineae) Polski, W. Kon o packa badała grzyby pasożytnicze okolic Skierniewic. Na Stacji ochrony roślin $w$ Warszawie pracowali - J. Trzebiński, W. Gorjaczkowski i Z. Zweigbaumówna.

Glony okolic Warszawy były badane przez H. Wys ocką (Desmidiaceae -2 prace). H. H u m b le t-F'a w łow sk a zbadała zmienność fitoplanktonu w osadniku na Stacji Pomp Rzecznych w Warszawie, A. L u e r-J e zi or ańska - plankton rzeki Jeziorki. S. Wis łou c h przeprowadził sanitarno-biologiczne badania Wisły i studzien w Pruszkowie.

Mszaki okolic Warszawy zostały zbadane zespołowo: B. H r y nie- 
wiecki, K. Stefanowicz-Owczarska, I. Rejmentówna i K. Lublinerówna.

Do historii botaniki należy cenna praca J. Rostafińskiego „Królewskie ogrody botaniczne króla Jana Kazimierza w Warszawie oraz spis systematyczny roślin tam hodowanych" (1928).

B. Hryniewiecki ogłosił następujące życiorysy: Stanisław Wisłouch, Ferdynand Karo, Jerzy Aleksandrowicz, Karol Drymmer, Wojciech Jastrzębowski, Józef Trzebiński, Hipolit Cybulski i Edward Strasburger-J. Kołodziejczyk ogłosił życiorysy Józefa Rostafińskiego i Feliksa Berdau'a.

\section{$\mathrm{V}$}

Wojna z najeźdźcą hitlerowskim doprowadziła do ruin Warszawy i zadała ciężkie ciosy Ogrodowi Botanicznemu. Wskutek działań wojennych w roku 1939 zburzone zostały dwie szklarnie (palmiarnia i paprociarnia), cztery inne $\mathrm{z}$ bogatymi kolekcjami mogły po naprawieniu ogrzewania centralnego nadal funkcjonować. Zdawało się, że uda się utrzymać do końca wojny Ogród, jako instytucję użytkowności publicznej, nawet po zamknięciu Uniwersytetu. Straty zadane Ogrodowi podczas działań wojennych częściowo wyrównano dzięki ofiarnej pracy personelu i Ogród przez 3 lata pełnił jak mógł swą rolę dydaktyczną, ciesząc się ponadto dużym zainteresowaniem mieszkańców Warszawy, zwłaszcza wobec zamknięcia dostępu do innych parków. To było solą w oku okupantów. W sierpniu 1942 r. z inicjatywy wysłannika władz hitlerowskich prof. W il h e lm a H ertera, wyznaczonego na kierownika Zakładów Botanicznych w Krakowie, po diwóch jego krótkich wizytach w Warszawie usunięto personel naukowy i przyłączono Ogród do parku Łazienkowskiego, pozostającego pod zarządem generał-gubernatora, tym samym zamykając do niego dostęp Polakom. Zaczęła się wówczas dewastacja Ogrodu i szklarni. Powstanie warszawskie stało się wreszcie pretekstem do kompletnego zniszczenia przez hitlerowców wszystkich budynków. Oprócz strat materialnych Ogród i Zakład Systematyki Roślin poniósł ciężkie ofiary w ludziach. Rozstrzelany został w Warszawie (30. XI. 43) jako zakładnik długoletni asystent dr Tadeusz Wiśniewski bryolog, fitogeograf, podróżnik po Kaukazie, Bałkanach i Afryce. Wywieziony po powstaniu dr Leszek Korzeni ew ski, który rokował duże nadzieje ze względu na swe prace w dziedzinie biometryki, został zastrzelony (w r. 1945) przy przepędzaniu jeńców z obozu do obozu podczas ostatniej ofensywy aliantów. Zmarła w r. 1941 asystentka mgr $\mathrm{H}$ a l i n a K a r m a z y ń s k a- 
- Przew a lska, autorka pracy o jemiole i współautorka (ze zdolną botaniczką dr Teklą C y gow ą zamordowaną w getcie) pracy o roślinach wiosennych. W r. 1942 zmarł ogrodnik parkowy Mieczysław Dąb r ow ski.

Po uwolnieniu Warszawy od okupanta hitlerowskiego przez zwycięską Armię Radziecką i Wojsko Polskie, Ogród Botaniczny przedstawiał straszliwy obraz zniszczenia. Najpierw należało zniszczyć obficie zostawione miny, później na wiosnę 1945 brygady robotnicze z grubsza oczyściły teren. Jesienią 1946 r. ustawiono prowizoryczny barak; można było po raz pierwszy po wojnie wydać katalog nasion do wymiany i nawiązać na nowo kontakt z zagranicznym światem naukowym. We wstępie do tego katalogu prof. B. Hryniewiecki pomieścił w języku angielskim historię Ogrodu pociczas okupacji hitlerowskiej (1939-1944). Ogrodem interescwał się najbliższy jego sąsiad Prezydent B ole s ła w B i e r u t, którego osobistej interwencji zawdzięczać należy możność poczynienia już wówczas niektórych inwestycji. Wielką pomocą przy oczyszczaniu Ogrodu okazały drużyny młodzieżowe zwłaszcza ze Związku Walki Młodych.

W 1946 r. Zarząd Stołecznego Miasta Warszawy i Wydział Plantacji Miejskich udzielił znacznej pomocy rzeczowej, pokrywając wydatki na utrzymanie licznych robotników dniówkowych, dostarczając nasion traw do obsiewania trawników, tak że w roku 1946 Ogród został oczyszczony i pozostała do wykonania tylko długa i mozolna praca restytucji etykietek i przegrupowania kolekcji.

W roku 1947 wykonano i zatwierdzono wszystkie plany odbudowy gmachów i szklarni w Ogrodzie Botanicznym. W r. 1948 odbudowano dwa pierwsze pawilony, w których znalazł pomieszczenie Zakład wraz z odzyskanym zielnikiem, małe muzeum, nasieniarnia i kancelaria Ogrodu. Jednocześnie zostały doprowadzone do porządku dwie stare szklarnie, które - dzięki wymianie nasion i roślin i dzięki pomocy udzielonej przez Ogród Krakowski oraz niektórych prywatnych ofiarodawców - szybko zapełniły się kolekcją roślin.

Uzyskanie jednej większej sali i paru pokoi w gmachu Obserwatorium rozwiązało sprawę prowadzenia wykładów i ćwiczeń dla zwiększonej liczby studentów. Wreszcie w r. 1952 wzniesiono pięć nowych szklarni i odbudowano dwa ostatnie wschodnie pawilony, gdzie znalazły pomieszczenie pracownie Ogrodu, biblioteka Polskiego Towarzystwa Botanicznego i mieszkania niektórych pracowników.

W Ogrodzie oprócz restytucji dawnych grup, stworzono nowe obszerne alpinarium, odremontowano i rozszerzono baseniki z roślinami wodnymi, założono dział roślin chronionych i użytkowych.

W roku 1953 W. Gajewski i L. Karpowiczowa wydali 
Przewodnik po Ogrodzie Botanicznym Uniwersytetu Warszawskiego ze wstępem historycznym B. H r yniewie ckiego.

Ogród ten jak wszystkie dotychczasowe Ogrody ma charakter dydaktyczno-muzealny. Tymczasem nowaczesna systematyka jest nauką dynamiczną i wymaga oparcia się na szerokim doświadczalnictwie. Z inicjatywy Zarządu Polskiego Towarzystwa Botanicznego został opracowany projekt takiego Instytutu Botaniki Doświadczalnej, który znalazł uznanie zarówno w Biurze Odbudowy Stolicy, jak i w Ministerstwie Rolnictwa i Szkolnictwa Wyższego a będzie realizowany przez Polską Akademię Nauk. O tych projektach pisał B. Hrynie wiecki w Skarpie Warszawskiej (II, 1946), w Biologii w Szkole (1949) i w Stolicy (VI, 1951) a także Z. H ellwig w Stolicy (V, 1950).

Pomimo ciasnoty adiunkci Ogrodu znaleźli sobie kącik, gdzie mogli wykonać cenne prace badawcze.

L. Karpowiczow a prowadzi badania nad aklimatyzacją cennej rośliny włóknistej - rami (ramia) (Boehmeria nivea). Patrz artykuły we Wszechświecie (1951), w „Przemyśle Włókienniczym" (nr 11, 1951 i w Acta S.B.P. (XXI, 2. 1952). Osobno wyszła praca: „Rami Boehmeria nivea Hook. d. Arn. Próby aklimatyzacji (V. W. N. 1954).

Doc. dr W. Gajewski od r. 1946 do r. 1954 na terenie Ogrodu przeprowadził cenne badania cytogenetyczne nad gatunkami r. Anemone, uzupełniając cytologicznie badania prof. E. Janczewskiego, wyjaśniając zjawiska poliploidalności a następnie od kilku lat pracuje nad zmiennością w rodzaju Geum dla całego świata. Asystentka Ogrodu mgr A. Michalsk a przeprowadziła badania cytologiczne nad rodzajem Luzula.

Zakład Systematyki i Geografii Roślin poniósł ciężkie straty w wyposażeniu naukowym. Zginęła $\mathrm{z}$ drobnymi wyjątkami cała aparatura naukowa, jak mikroskopy i inne utensylia. Duże straty poniosła również Biblioteka. Przy ulicy Traugutta spłonęła biblioteka dr F. Błońs ki e go. Udało się z niej uratować i ukryć dwadzieścia kilka tomów bardzo cennych dzieł zielnikowych z XVI, XVII i XVIII wieku. Historię i znaczenie tej biblioteki podał B. Hryniewiecki (Spraw. TNW 1952). Większa natomiast część książek Zakładu została przekazana Bibliotece Uniwersyteckiej, wobec jednak wyniszczającej gospodarki okupanta hitlerowskiego i celowego przerzucania książek z jednej biblioteki do drugiej, nie wszystkie książki dało się odszukać. Ciężką stratą było spalenie „Index Kewensis" Jeżeli dodamy, że spłonęły również biblioteki prywatne kierownika Ogrodu prof. B. Hryniew i e ckiego i jego pomocnika prof. R. Kobendzy wraz z rękopisami, musimy przyznać, że straty były olbrzymie. 
Pocieszającym faktem jest, że ocalały prawie wszystkie gromadzone przez długie lata zieiniki, zabezpieczone w Muzeum Narodowym. Część ich, która znajdowała się w portatywnych pudłach została przez okupantów wywieziona na Sląsk. Kolekcja ta wraz z licznymi obiektami należącymi do Muzeum wróciła do Warszawy, gdzie dzięki odbudowie jednego pawilonu w Ogrodzie zielnik znalazł daleko lepsze pomieszczenie niż miał przed wojną. Ocalała również bezcenna „Iconotheca botanica“ patriarchy W. Z a l e ski e g o ukryta starannie przed okiem okupantów.

Widzimy, że warszawscy botanicy znaleźli się w niezmiernie ciężkim położeniu, gdyż w pierwszych latach po wojnie należało skierować wysiłki przede wszystkim na odbudowę zniszczonych warsztatów pracy. Pomyślną okolicznością dla florystów jest nowe ilustrowane wydanie „Roślin Polskich“ W. Szafera, S. Kulczyńskiego i B. Pawłow. skiego (1953) oraz 15 wydanie Przewodnika prof. J. Rostafińskiego staraniem dr Olgi Seidl (1953).

W okresie tym zwrócono specjalną uwagę na drzewa w okolicach Warszawy. Cenne są pod tym względem prace R. Kobendzy (Wisienka kwaśna, nowy mieszaniec lipy Tilia varsaviensis, Betula humilis, topole, zmienności dębu), A bramowicz pisała o jodle, Szymanowski o wiązach i tulipanowcach, W. Pl a pis pisał o odbudowie lasów w warszawskim zespole miejskim (1950).

Sporo prac poświęcono rezerwatom i parkom ochrony przyrody. Zwłaszcza R. Kobendza poświęcił szereg prac rezerwatom w puszczy Kampinoskiej, przedstawiając „Materiały przyrodnicze do projektu rozplanowania puszczy Kampinoskiej“ poparte doskonałymi fotografiami (1945) a następnie na łamach czasopisma „Chrońmy Przyrodę“ zwracając uwagę na rozmaite fragmenty tej puszczy, pisał również o rezerwacie leśnym w Wawrze pod Warszawą. W książce S. J a r o s z a „Parki narodowe i rezerwaty przyrody“ znajdujemy również zestawienie i opis rezerwatów okolic Warszawy i woj. warszawskiego (1951). Niektóre cenne parki zostały opracowane z punktu widzenia historycznego i konserwatorskiego jak G. Ciołka - Wilanów (1947) S. Lorentza- Natolin (1948) i J. We g ner - Arkadia (1948). J. P o rę b ski opisal parki w powiecie grójeckim (1948).

W dziale roślin zarodnikowych nad glonami Wisły pracowała $\mathrm{H}$. W ysocka, ogłaszając dwie cenne prace dotyczące pleustonu i perifitonu w Wiśle w okolicach Warszawy.

W dziele grzybów A. Skirgiełło opracowała monograficznie rodzaj Russula (gołąbki, surojadki) dla całej Polski; są tam i materiały zebrane pod Warszawą, zwróciła również uwagę na grzyb piaskowy (Pisolithus arenarius) i napisała popularną książeczkę o pieczarce. Ostatnio wyszła 
jej cenna monografia „Grzyby niższe, Pragrzyby i glonowce 1954. Można tu wspomnieć o popularnych książeczkach O $\mathrm{r}$ osia, dotyczących grzybów trujących i jadalnych.

Z mszaków szczegółowo były opracowane wątrobowce przez I. R e jment-Grochowską na materiale pochodzącym między innymi z okolic Warszawy.

W tym okresie prof. B. Hryniew ie cki ogłosił sporo przyczynków do historii botaniki w Polsce. Pisał o dawnych ogrodach botanicznych w Warszawie (1948, 1951), wydał pracę o botanice w Warszawskim Towarzystwie Przyjaciół Nauk, wyróżniając zasługi M. Szuberta i dał serię życiorysów polskich botaników związanych z Warszawą, jak W incenty Siemaszko, Tadeusz Wiśniewski, Wacław Niedziałkowski, January Kołodziejczyk, Jakub Waga, Józef Rostafinski, Franciszek Kamieński, R. Kobend z a pisał o Stefanie M a kowieckim (1951).

\section{SKRÓTY}

PF - Pamiętnik Fizjograficzny.

SKF - Sprawozdanie Komisji Fizjologicznej.

$\mathrm{K}$ - Kosmos.

$\mathrm{W}$ - Wszechświat.

PTB - Polskie Towarzystwo Botaniczne.

SBP - Societes Botanicorum Poloniae.

PAU - Polska Akademia Umiejętności.

PAN - Polska Akademia Nauk.

PTDendr. - Polskie Towarzystwo Dendrologiczne.

\section{VI}

\section{BIBLIOGRAFIA PRAC DOTYCZĄCYCH FLORY I ROSLINNOŚCI OKOLIC WARSZAWY.}

1952 A. A bramowicz. Nowe stanowiska jodły na północno-wschodniej granicy zasięgu. - R. VIII. Sek. Dendr. PTB 1952, str. 32-98.

1861 J. A leksandrowicz. M i chał Szubert. - Tyg. Ilustr. 1861, z portr. 1872 J. Aleksandrowicz. Budowa i rozwój zarodni śluzowców. - Warszawa. 1872 (po ros.), (64 gatunki z okolic Warszawy).

1894 J. A leksandrowicz i F. Błoński. Grzyby jadalne i trujące. - Encykl.

Roln. III. Warszawa. 1894, str. 593-616.

1856 J. B a r tos z e wi c. z. Łazienki. - Księga Swiata. R. V. 1856, str. 147-151.

1876. F. Berdau. Porosty zbadane dotychczas w obrębie Warszaw. okręgu nauk. 
ze wskazaniem na morfologię i fizjologię porostów w ogóle. Warszawa. 187હ, str. $1-125$ (po ros.).

1889 F. B errda u. Grzyby krajowe trujące. - Warszawa. 1889.

1652 M. B ernhardi (nobil. od r. 1673 jako de Bernitz). Catalogus plantarum tam exoticarum quam indigenarum quae anno MDCLI in hortis regiis Varsaviae et circa eandem in locis sylvaticis, pratensibus, arenosis et paludosis nascuntur collectarum. Dantisci. 1652.

1888 F. Błoński. Materiały do flory skrytokwiatowej. Wątrobowce Królestwa Polskiego (Hepaticae Polonicae). - PF. VIII C, 1888, str. 156-202, 4 tabl.

1888 F. Błoński. Dodatek do monografii wątrobowców Królestwa Polskiego zamieszczonej w niniejszym tomie. PT VIII C, 1888, str. 384-387.

1889 F. Błoński. Materiały do flory skrytokwiatowej krajowej. Conspectus muscorum Poloniae. Mchy Królestwa Polskiego. Cz. I. Mchy bocznozarodniowe. Bryinae Pleurocarpae. - PF IX. 1889, str. 119-214, z 7 tabl.

1890 F. Błoński. Mchy bocznozarodniowe. Bryinae Pleurocarpae. PF X, c, 1890, str. $191-243$, z 4 tabl.

1892 F. Błoński. Przyczynek do flory jawnokwiatowej oraz skrytokwiatowej naczyniowych kilkunastu okolic kraju. - PF XII c, 1892, str. 129-149.

1896 F.Błonski. Przyczynek do flory grzybów Polski (Symbolae ad floram mycologicam Poloniae). - PF XIV.-1896, str. 63-93.

1888 S. Chełchowski. Grzyby podstawkozarodnikowe okolic Warszawy. Warsz. Uniwers. Izwiestja. Warszawa. 1888 (po ros.).

1898 S. Chełchowski. Grzyby podstawkozarodnikowe Królestwa Polskiego. (Basidiomycetes polonici). Cz. I. Autobasidiomycetes. - PF XV, c. 1898, str. 3-285. 1898 S. Chełchowski. Róża pęcherzykowata sosny amerykańskiej w Rakowcu pod Warszawą. - W. XVII, 1898, s. 350-351.

1905 S. Chełch ows ki. Trufle Warszawskie. W XXIV, 1905, str. 525-526.

1907 S. Chełchowski. Aleksander Zalewski. - W. XXVI, 1907, str. $129-133$.

1946 G. C i ołe k. Ogród Łazienkowski. - Skarpa Wanszawska. Warszawa nr 24.

1947 G. Ci łłek. Ogród w Willanowie. Badania i zagadnienia konserwatorskie.

- Biul. Hist. Szt. i Kult. R. IX. 1947, nr 1-2, str. 86-128.

1952 G. C i ołe k. Ogród w Nieborowie. Warszawa. Rkp.

1883 Kazimierz Cybulski. 'Materiały do flory algologicznej okolic Warszawy. - PF IIII. 183, str. 249-273, 5 tabl. rys.

1887 Hipolit Cybulski. Topola włoska z żeńskimi kwiatami w Warszawie. W. 1887 , str. 282.

1893 H. Cy bulski. Rośliny rzadkie lub zupełnie nieobserwowane dotąd w kraju, zebrane w okolicach Warszawy. - W. XII. 1893, str. 847.

1894 H. C y buls ki. Spis rzadkich roślin zebranych w bliskich okolicach Warszawy i na przedmieściu Pradze w lecie i jesieni r. 1893. - W. XIII, 1894, s. 155-15; $173-174$.

1894 H. Cybulski. Dianthus arenarius i Vicia lathyroides w pobliżu Warszawy. - W. XIII, 1894, str. 333.

1894 H. Cybulski. Rubus caesius w pobliżu Warszawy. - W. XIII, 1894, str. 382.

1894 H. Cybulski. Oenothera muricata w pobliżu Warszawy. - W. XIII, 1894, str. 413.

1894 H. Cybulski. Porównanie Oenothera muricata z Oen. biennis. - W. XIII, 1894, str. 622 . 
1894-5-6 H. Cy bulski. Spis roślin rzadkich lub zupełnie dotąd nieobserwowanych w kraju zebranych w okolicach Warszawy w r. 1894. - W. XIII, 1894, str. 829. - XIV, 1895, str. 94-95, 107-108, 122-123. - XV, 1896, str. 141-142, $159-160$.

1895 H. Cybulski. Achillea nobilis wr okolicach Warszawy. - W. XIV, 1895. str. 622 .

1895 H. Cybulski. Rośliny okolic Warszawy rzadkie albo zupełnie dotąd nieobserwowane w kraju, zebrane w okolicach Warszawy w r. 1895. - W. XIV, 1895, str. 829.

1895 H. Cybulski. Lycopodium inudatum L. w pobliżu Warszawy. - W. XIV, 1895 , str. 653.

1896-1897 H. C y bu ls ki. Spis gatunków rzadkich albo dotąd w kraju nieobserwowanych zebranych w okolicach Warszawy w 1896 r. - W. XV. 1896, str. 830. - XVI, 1897, str. 76-77.

1929 M. Czyrsznicówna. Studia nad chwastami z okollic Warszawy.

- R. Nauk Agron. i Leśn. Poznań XXI, 1929, str. 1-44, 16 tabl. rys.

1886 L. Dę b i cki. Powązki i Puławy. 1786-1794. - Przewodnik Nauk i Liter.,

Lwów. 1886.

1933 Dom, Osiedle i Mieszkanie. R. V. 1933, zesz. 10-11 (zeszyt poświęcony sprawie lasów podmiejskich).

1932 Z. D r y jó w n a. Statystyka biologiczno-kwiatowa flory polskiej. Spraw. z pos. TNW, Wydz. IV, XXIV, 1932, str. 203-237.

1885 K. Drymmer. Spis roślin zebranych w r. 1884 w powiecie kutnowskim, w okolicach Zychlina, Krośniewic i Ordowa. - PF V c, 1885, str. 39-66, z 1 mapką.

1890 K. Drymmer. Dodatek do spisu roślin powiatu kutnowskiego, mianowicie z okolic Żychlina. - PF X C, 1890, str. 75-82.

1908 K. D ry m me r. Matricaria discoidea DC. - W. XXVII, 1908, str. 700 (Rawa).

1930 S. D zi u bałtowski. Rezerwat jodłowy w Mieni pod Mińskiem Mazowieckim. - P. Rada Ochr. prz. nr 26. - Las Polski 1930, nr 1, z 2 rys.

1730 Chr. H. Erndtel. Warsavia physice ilustrata sive de aere, aquis, locis et incolis Warsaviae, eorundemque moribus et morbis tractatus, cui annexum est Viridarium vel Catalogus plantarum circa Warsaviam nascentium. Drezno 1730.

1881 K. Filipowicz. Spis mchów, wątrobowców i porostów z niektórych stanowisk Królestwa Polskiego, a mian. z doliny Ojcowskiej, Bentkowskiej, okolic Warszawy, Łukowa, Puław, Brześcia Litewskiego, zebranych i oznaczonych w latach 1877 i 1879 . - PF 1881, I Q III, str. 258-267.

1919-1947 Flora Polska. Rośliny naczyniowe Polski i ziem ościennych. T. I. Paprotniki, iglaste i nagonasienne pod redakcją M. Raciborskiego i W. Szafera w opracowaniu zbiorowym. PAU Kraków. Dotąd wyszły pod red. W. S z a f er a tomy: I, II, III, IV, V, VI. Od 1919-1947.

$1946 \mathrm{Gajewski} \mathrm{W.} \mathrm{Cytogenetic} \mathrm{studies} \mathrm{on} \mathrm{Anemone} \mathrm{L.} \mathrm{I.} \mathrm{Anemone} \mathrm{Janczew-}$ skii a new species of amphiploid origin. ASBP., 16.

1947 W. Ga jewski. Cytogenetic studies on Anemone L. II. Hybrids among Anemone virginiana, A. silvestris and A. multifida. ASBP., 18.

1948 W. Gajewski. On the chromosome pairing in six hybrids among four

Geum species. - ASBP., 19.

1949 W. Gaj ews $\mathrm{ki}$. The behaviour of univalents at meiosis in some interspecific Geum hybrids. Hereditas, 35. 
1951 W. Grajewski. The inheritance of specific traits in the hybrids Geum coccineum x G. rivale. - ASBP., 20.

1952 W. Grajewski. The hybrids between two subgenera of Geum. ASBP., 21.

1953 W. G a jewski. The hybrid G. rivale x G. macrophyllum and its amphiploid progeny. - ASBP., 22.

1953 W. Gajewski i L. Karpowiczowa. Przewodnik po Ogrodzie Botanicznym Uniwersytetu Warszawskiego. Rys historyczny napisał B. Hryniewiecki. Warszawa 1953. PWN, s. 122 , z 17 ryc. i 1 planem.

1954 W. Gajewski. Amphiploid hybrid of Geum urbanum L. and G. moile Vis. et $\mathrm{P}$ a n c - ASPB., 23.

1932 K. Gajl i R. Kobendza. Bielany pod Warszawą i konieczność ich ochro-

ny. - P. Rada Ochr. Przyr. nr 33. Warszawa 1932, str. 37, ryc. 3.

1935 J. G a w i now a. Materiały do zoocecidiologii Mazowsza. Spraw. TNW, XVIII. 1935, str. 43 , z 3 tabl.

1932 E. Grabda. Walka o lasy podm:ejskie. - Czasopismo Przyrodnicze. Łódź, VI, 1932, zesz. $7-8$.

1923 J. Graff. Z zabytków roślinności pod Warszawą. - Ziem:a, VIII, 1923, str. 197, z 1 ryc. (2 dęby).

1931 W. Grochows ki. Flora Wilanowa i okolic. - Bibliot. Wiad. Farmaceut.

T. 15. 1931.

1931 W. Grochowski. Sporysze polskie. - Wiad. Farm. 58, 1931.

1925 R. Gumiński, M. J a sińska, R. Kobendza. Jeziorko Czerniakowskie.

Prace Zakł. Geog. Un. Warsz. nr 3. Warszawa. 1925, str. 20 z ryc.

1950 Z. Hellwig. Nowy Warszawski Ogród Botaniczny. - Stolica R. V. nr 49, 1950 , str. 5.

1902 B. Hryniewiecki. Elodea canadensis. - W. XXI, 1902, str. 622 (Urle koło Łochowa).

1910 B. Hryniewiecki. Franciszek. Błoński. - K. XXXV. 1910, str. 792-799, z portr.

1911 B. Hryniewiecki. Wschodnia granica buka w Europie. - K. XXXVI, 1911, str. 225-242, z 2 map.

1913 B. Hryniewiecki, Franciszek Kamieński i jego zasługi naukowe. - K. XXXVIII, 1913, str. 156-169, z portr.

1927 B. Hryniewiecki. Rzut oka na szatę roślinną Polski. - Przewodnik

Kongr. II Zjazdu Stow. Geogr. i Etnog. w Polsce. 1927.

1927 B. Hryniewiecki. Flora na przestrzeni od Warszawy do Wilna. Przew.

Kongr. Geogr. i Etnogr. w Polsce. Kraków 1927, str. 156-157, 175-176.

1928 B. Hryniewiecki. Coup d'oeil sur la flore de la Pologne. - Guide des excursions en Pologne. V-me Exc. Phyt. Intern. 1928.

1928 B. Hryniewiecki. Varsovie et ses environs. - Guide des exc. en Po-

logne. XV partie V. I. P. E. Kraków 1928, 160, str. 18.

1929-30-31 B. Hryniewiecki. Sprawozdan:e z działalności Warsz. Kom.

Ochr. Przyr. za lata 1929-30. - Ochrona Przyrody R. 10, 1930, str. 196-200

z 2 ryc., R. 11. 1931, str. 177-179.

1930 B. Hryniewiecki. Olcha szara (Alnus incana Moench) w Polsce i na

Litwie oraz jej mieszańce. - Sylwan R. XLVIII, Lwów, 1930.

1931 B. Hryniewiecki. Stanisław Wisłouch. - Acta SPB VIII, $3 / 4,1931$.

1931 B. Hryniewiecki. Ferdnand Karo. - Acta SBP, VIII, 3/4, 1931. 
1932 B. Hryniewiecki, Las Wawerski. - Dom, Osiedle i Mieszkanie. R. V. 1932, $\mathrm{nr} 10-11$.

1932 B. Hryniewiecki. Walka o zieleń i powietrze dla Warszawy. Kurjer Poranny 1932, $\mathrm{nr} 169$.

1932 B. Hry n i e w i e cki. Urbanistyka a Przyroda. - Kurjer Poranny, 1932, nr 176. 1932 B. Hry ni ew i e cki. Walka o las wawerski pod Warszawą. - Ochrona Przyrody. R. 12,1932 , str. $152-5$, 1 ryc.

1932 B. Hryniewiecki i R. Kobendza. Przewodnik po Ogrodzie Botanicznym Un. Warsz. 1932, str. 146, ryc. 34, 6 tabl., 1 plan.

1933 B. Hry nie w i e cki. O niektórych sosnach osobliwych kształtów w okolicach Warszawy. - R. Pol. Tow. Dendr. V. Lwów, 1933, str. 176-9, z 6 rys.

1934 B. Hry niew i e cki. Lasy okolic Warszawy, ich znaczenie i ochrona. - Kronika Warszawy, $\mathrm{nr}$ 1934, str. 13, z 2 map.

1934 B. Hry ni e wi e cki. Les Jardins Botaniques en Pologne. - Le Centenaire du Jardin Botanique de Dijon. P. G enty. Dijon. 1934.

1935 B. Hryniewiecki. Jerzy A leks androwicz (1819-1894) - Pol. Slown. Biogr. PAU, t. I, 1935, str. 68-69.

1937 B. Hryniewiecki. Karol Drymmer. - Acta SBP, XIV, 4. 193 . - Pol. Słown. Biogr. PAU, t. V, 1939-1946, str. 408.

1937 B. Hryniewiecki. Wojciech J a strzębowski. - R. Nauk Ogr. 1937, str. 21. - Księga Pamiątkowa SGGW, 1937, str. 14.

1937 B. Hryniewiecki. Dr Józef Trzebiński. Czterdziestolecie pracy naukowej. - Acta SBP. XIV, 4, 1937.

1937 B. Hryniewiecki, K. Stefanowicz-Ow c z a r s ka, I. R e jmentówna, K. L u bli n e r ó w n a. Mszaki okolic Warszawy. Bryophyta Varsaviensia. - Planta Pol. TNW, t. VI, 1937, str. 1-118, 4 rys. i 1 mapa.

1938 B. Hryniewiecki. W Ogrodzie Botanicznym kwitną „bzy“. - Ogrodnik.

R. XXVIII, nr 9, Warszawa 1938, str. $129-133$ z rys.

1938 B. Hryniewiecki. Hipolit Cy bulski (1828-1900). - Pol. Slownik Biogr. PAU, t. IV, Kraków 1938, str. 116.

1946 B. Hryniewiecki. The History of the Botanic Garden of the Warsaw University during the german occupation (1939-1944). Index seminum Horti Bot. Vars. 1946, p. 1-2.

1946 B. H r y n i e w i e c k i. Ogród botaniczny. Wiczoraj, dziś i jutro. - Skarpa Warsz.

R. II, 1946, $\mathrm{nr}$ 10, str. 4-5.

1947 B. Hryniewiecki. Wincenty Siem as z ko (1887-1943). - Acta SBP, XVIII, 1. 1947, str. 117-128 z portr. - Spraw. 58 Kasy im. Mian. za lata 1939-1948. (Skrót).

1948 B. Hryniewiecki. Tadeusz Wiśnie s ki (1905-1943). — Acta SBP XIX, 2, 1948, z portr.

1948 B. Hryniewie cki. Warszawskie ogrody botaniczne. - Biologia w Szkole, nr 2, 1948, str. 47-53.

1949-50 B. Hryniewiecki. Wacław Niedziałk ow ski. — Acta SBP, $\mathrm{XX}, 1,1949-50$, str. $331-335 \mathrm{z}$ portr.

1949-50 B. H r y nie wi e cki. January Ko lodzie j c z y k. - Acta SBP, XX. 1, 1949-50, str. 337-346, z portr.

1951 B. Hryniew iecki. Botanika w Warszawskim Towarzystwie Przyjaciół Nauk. - Acta SBP, XX, Suppl. 1951, str. 3-32 z portr. 
1951 B. Hryniewiecki. Jakub W a ga (w 150 roczn. ur.) - Acta SBP, XX, Suppl. 1951, str. $33-45, \mathrm{z}$ portr.

1951 B. Hryniewiecki. Józef Rostafiński (w setną rocznicę ur.). Acta SPB, XX, Suppl. 1951, str. 47-76, z portr. i 3-ma tabl. ryc.

1951 B. Hryniewiecki. Franciszek K a m i én s k i (1851-1912), (w setną rocznicę urodzin). - W. 1951, zesz. 4, str. 103-106, z portr.

1951 B. Hryniew iecki. Stary i nowy Ogród Botaniczny. - Stolica R. VI, 1951. 1952 B. Hryniewiecki. Józef Rostafiński. - Problemy (skrót) VIII, 1952, $\mathrm{nr}$ 7(76), str. 491-2, z portr.

1952 B. Hryniewiecki. Biblioteka dr F. Błońskiego. - Spraw. TNW, XLII, 1949 (1952), str. 44-49.

1939 H. H u mblet-Pawłowska. Roczna zmienność fitoplanktonu w osadniku na Stacji Pomp Rzecznych w Warszawie. - Planta Polonica WTN, t. VIII, 1. 1939, str. 26, 1 rys. w tekście, 16 wykresów, 5 tablic.

1928 K. J a n k ow ska. Zewnętrzniaki polskie. - Pam. Inst. Nauk. Gosp. W. Puław.

t. IX, Puławy, 1928.

1910 E. J a nkowski. Zadrzewianie miast naszych. Warszawa 1910, str. 75.

1922 E. Jankowski. Zadrzewienie Warszawy współczesnej. Ziemia VII, 1922, str. $335-341$, z 2 ryc.

1934 E. Jankowski. Pluca Warszawy. - Kronika Warszawy, nr 4, 1934.

$195 \overline{1}$ S. J a rosz. Parki Narodowe i rezerwaty przyrody. — „Kraj“, Spółdz. Inst. Wyd. 1951. Zestawienie i opisy parków narodowych i rezerwatów przyrody. Warszawa i woj. warszawskie, str. 22-30.

1643 A. J a rzę bski. Gościniec albo opisanie Warszawy. 1643. Warszawa 1909.

1829 W. Jastrzębowski. Rośliny ciekawsze znalezione w Królestwie Polskim - Pamięt. Warsz. Um. Scisł. i Stosow. IV, 1829, str. 183-194.

1922 W. Jedliński. O granicach naturalnego zasięgu buka, jodły i świerka. Zamość 1922 .

1926 W. Jedliński. O pasie bezświerkowym na ziemiach polskich i jego znaczeniu hodowlanym. - Las Polski. Warszawa, 1926.

1927 H. Juraszkówna. Pflanzenbiologische Studien über die Dünen bei Warschau. - Bull. Int. d. l' Acad. S. et L. Kraków, 1927.

1933 L. J. Kalinowska. - Natolin. Opis parku. - Pol. Tow. Dendr. R. V, Lwów, 1933.

1879 F. K a m i ń s k i. Wiadomość o roślinie wodnej Elodea canadensis SKF PAU, XIII, 1879, str. $264-265$.

1884 F. K a m iłeńs ki. Nowy nabytek flory polskiej. - PF IV, 1884, str. 266-271, z 4 rys. (okolice Warszawy).

1884 F. K a m i'eńs k i. Nowy nabytek flory krajowej. - W. III, 1884, str. 517-518 (okolice Warszawy).

1885 F. K a mieński. Spis paproci krajowych. - PF. V. E. 1885, str. 109-111.

1884 F. K a r o. Einiges über die Flora der Umgebung von Warschau. - Oest. Bot. Zeit. 1867, str. $397-399$.

1951 L. Karpowiczowa. Rami (Boehmeria nivea). - W. 1951, zesz. 3.

1951 L. Karpowi c zow a. Rami. - Przemysł Włókienniczy. 1951, nr 11.

1952 L. Karpowiczowa. Z doświadczeń nad Boehmeria nivea w Ogrodzie

Bot. Un. Warsz. - Acta SBP, XXI, 2.

1927 K. Kleistówna. Recherches phytosociologiques sur les tourbières de la 
région des dunes de la rive droite de la Vistule aux environs de Varsovie. - Bull. Int. de l'Acad. Cracovie 1927.

1954 L. Karpowiczowa. Rami. Boehmeria nivea (L.) Hoo'k, et A rn. Próby aklimatyzacji. - Hortus Bot. Varsav. Warszawa, 1954. PWN, str. 41, z 13 rys.

$1929 \mathrm{~K} . \mathrm{K}$ le is tówna. Badania nad zespołami roślinności torfowisk obszaru wydmowego prawego brzegu Wisły pod Warszawą. - Rozprawy PAU, t. LXIX B, nr $5,1929$.

1922 R. Kobendza i J. K o 1 odzi e j c z y k. Przewodnik florystyczny po okolicach i parkach Warszawy. Z przedm. prof. B. Hry n i ew i e ck i e g o. M. Arct. Warszawa, 1922, str. 101.

1924 R. Kobendza. Projekt rezerwatu w puszczy Kampinoskiej. - Las Polski.

P. Rada Ochr. Przyr., nr 5, 1924, str. 12, 1 mapa.

1925 R. Kobendza. Modrzewina w Małej Wsi pod Grójcem. - Las Polski, nr 8, Warszawa 1925.

1927 R. Kobendza. Roślinność puszczy Kampinoskiej. - Krajobrazy roślinne Polski pod red. Z. W ó y c i c k i e g o, zesz. XIII, Warszawa 1927.

1929 J. i R. Kobendza. Cztery wycieczki do puszczy Kampinoskiej. - Warszawa 1929. Pol. Tow. Kraj. Biblioteczka Wycieczkowa, nr 8, str. 40.

1929 R. Kobendza. Bielany pod względem botanicznym. - Roczn. Nauk Roln.

i Leśn., t. XXII, Poznań 1929.

1930 R. Kobendza. Stosunki fitosocjologiczne puszczy Kampinoskiej. - Planta Polonica, II, 1930, TNW.

1930 R. Kobendza. Parki Warszawy i jej okolic. Park Ujazdowski, Park im. I. P a d e rew s ki e g o. - Pol. Tow. Dendroll. R. III, 1930, Lwów, str. 37, z 10 rys. i $2 \mathrm{pl}$.

1930 R. K o be n d za. Krótki przewodnik drzewoznawczy po parku I g n a c e g o

P a d e r e w s k e g o w Warszawie. 1930. Wyd. Wydz. Ośw. i Kult. Magist.

m. st. Warszawy. $16^{0}$, str. 51,7 ryc.

1932 R. Kobendza. Zawiewanie korzeni sosny przez piasek. - Acta SBP, IX, Suppl. 1932. str. $101-113, \mathrm{z} 7$ rys.

1933 R. K o bendza. Wpływ zimy 1928-29 na roślinność drzewiastą Ogrodu Bơta-

nicznego. - Pol. Tow. Dendr. V, 1933, str. 16, 5 ryc.

1933 R. K o bendzla. Szkice dendrologiczne. - P. Tow. Dendr. R. V, Lwów, 1933. 1933 R. Kobendza. Las wawerski ze stanowiska fitosocjologii. - Ochrona Przyrody. R. 13. Kraków 1933, str. 41-59.

1934 R. Kobendzia. Godny ochrony las w Lipkach pod Warszawą. - Ochrona

Przyrody. R. 14. Kraków. 1934, str. 67-75.

1934 R. K o b e nd zlla. Rzadkie gatunki roślin pod Warszawą. - Acta SBP, vol. XI, Suppl. 1934, str. 435-444.

1934 R. K orb e n d z a. Krótki zarys roślinności okolic Warszawy. - Ziemia R. XXIV, nr 9, Warszawa 1934, str. 208-217, z 9 ryc.

1935 R. Kobendza. Wpływ zimy majowej na roślinność okolic Warszawy

w 1935 r. - Pol. Tow. Dendr. R. VI, Lwów, 1935.

1936 R. K o b e n d z a. Przyczynek do poznania brzozy czarnej (Betula obscura K o t)

w Polsce. - Pol. Tow. Dendr. R. VI, 1936, Lwów, str. 14, ryc. 4 i 1 mapa.

1938 R. Kobendza. Drzewa i krzewy Ogrodu Botanicznego Uniwersytetu Warszawskiego. - Pol. Tow. Dendr. R. VII, 1938, Lwów, str. 50, ryc. 16.

1945 J. i R. Kobendza. Materiały przyrodnicze do projektu rozplanowania puszczy Kampinoskiej. - Czytelnik. Warszawa 1945, 14 tablic i 1 mapa. 
1946 R. Kobendza. Rezerwat „Zamczysko“ w puszczy Kampinoskiej. Chrońmy przyr. ojcz. Kraków, 1946, II, nr 5/6, str. 40-41.

1946 R. Kobendza. Z rezerwatów puszczy Kampinoskiej. - Chrońmy przyr. ojcz. II, 1946, nr 7/8, str. 59-61, nr 9/10, str. 38-42.

1947 R. Kobendza. Z rezerwatów puszczy Kampinoskiej. - Chrońmy przyr. ojcz. III, nr 1/2, 1947, str. 53-55.

1947 R. Kobendza. Projekt rezerwatu wisienki kwaśnej (Prunus acida K. Ko ch) na terenie puszczy Kampinoskiej. - Chrońmy przyr. ojcz. III, 1947, $\mathrm{nr} 5 / 6$, str. $34-35$.

1949 R. Kobendza. Nasze drzewa leśne jako element parkowy. - Stolica.

R. IV, nr 20, 1949, str. 9, 5 rys.

1949 R. K ob en d z a. Zakładajmy plantacje świerków i jodeł na choinki. - Chroń-

my przyr. ojcz. V, nr 7/8, 1949, str. 41.

1950 R. Kobendza. Rezerwat leśny w Wawrze pod Warszawą. - Chrońmy przyr.

ojcz. VI, nr $3 / 4$, str. $39-44$.

1951 R. Ko bendza. Wartościowy mieszaniec lipy węgierskiej i szerokolistnej Tilia

Varsaviensis (T. argentea x T. platyphyllos). R. VII, Sek. Dendr. PTB, 1951, str. $159-174$.

1951 R. Kobendza. Brzoza niska (Betula humilis Schrank) na torfowisku

Pulwy pod Wyszkowem. - R. VII, Sek. Dendr. PTB, 1951, str. 201.

1951 R. Kobendza. Sp. Stefan Makowiecki. - R. VII. Sek. Dendr. PTB, 1951 , str. $299-301$.

1962 R. Kobendza. Topole sekcji Leuce Duby w Polsce, ich zmienność i wyko-

rzystanie dla celów gospodarczych i zdobniczych. - R. VIII, Sek. Dendr. PTB, 1952, str. 32-98.

1952 R. K o b e n d z a. Różnopostaciowość liści dębu szypułkowego (Quercus robur L.)

pod wpływem uszkodzeń owadzich. - R. VIII, Sek. Dendr. PTB, str. 201-205, $1952 \mathrm{r}$.

1934 J. Ko chman. Przyczynek do znajomości flory głowni polskich. - Acta SBP, XI, Suppl. 1934, str. 285-303.

1936 J. Kochman. Grzyby głowniowe Polski. Ustilaginales Poloniae. Planta Polonica. T. IV, TNW, 1936.

1921 J. Kołodziejczyk. Krajobrazy roślinne nad Wisłą. Charakterystyka

i geneza. - Monografia Wisły VII, Pol. Tow. Kraj., Warszawa 1921.

1922 J. Kolodziejczyk. Rys florystyczny okolic Warszawy. - Ziemia. VII, 1922, str. $341-346$, z 2 ryc.

1927 J. Kołodziejczyk. Józef Rostalfiński. - W. 1927.

1935 J. Kołodziejczyk. Feliks Berda u. - Pol. Słown. Biogr. PAU I,

5 str. 445, Kraków 1935.

1915 K. K on arski. Pałac Brühlowski w Warszawie. Warszawa 1915. Opis i plan ogrodu.

1925 w. Konopacka. Rdze zbożowe w Skierniewicach w r. 1925. - Choroby szkodniki roślin. R. I, 1925.

1924 W. Konopacka. Spostrzeżenia nad występowaniem chorób na roślinach uprawnych w okolicy Skierniewic w r. 1924. - Choroby i szkodniki roślin, t. I, Warszawa 1924.

1927 W. Kon o pa ck a. Mączniak rzekomy na różach. - Rocz. Nauk. Roln., t. 18, Poznań 1927.

1901 J. Kowalczyk. Hipolit Cybuls ki. - W. XX. 1901, str. 28-29. 
1895 W. Kozłowski. Przyczynek do flory wodorostów okolic Warszawy. 1895, str. $65-73$.

1928 W. Krzyżkiewiczówna. Przyczynek do morfologii i anatomii jesiona (Fraxinus excelsior). R. II, Pol. Tow. Dendr. 1928, str. 17-33, z 6 ryc.

1889 F. Krzepiński. Agaricus lepideus Fr. w Leszczyźnie pod Dębem Wielkim. Warszawa. W. XIII, 1889, str. 698.

1952 W. Kurtzówna. Anthophysa vegetans Stein w Wiśle oraz rola jej przy ustalaniu żelaza w wodzie. - Acta SBP, XXI, 3. 1952, str. 401-415, z 4 wykr. i 6 rys. w tekście.

1948 S. Lorentz. Natolin. - Prace z hist. sztuki. TNW II, Warszawa, 40, str. 333, z 234 ilustr. w tekście.

1939 A. Luer-Jeziorańska. Materiały do flory pllanktonu rzeki Jeziorki. - Planta Polonica. Wyd. TNW, Vol. VIII, 2. 1839, str. 41, 1 rys. w tekście, 10 wykresów, 13 tablic.

1881 K. Ła p czyński. O Łukowskim płaskowzgórzu i nieco o jego roślinności. - PF I, 1881, str. 185-199.

1882 K. Łapczyński. O roślinności jawnokwiatowej okolic Warszawy. - PF II, 1882, str. 327-347.

1887 K. Łapczyński: Stosunek flory Królestwa Polskiego do roślinności całej powierzchni ziemi. - PF. VII, str. 3-43..

1888 K. Ła p czyński. Roślinność kilku miejscowości krajowych. III, Brwinów,

Kempin i las Młochowsiki. - PF, VIII C. 1888, str. 3-85.

1890 K. Łapczyńs ki. Z flory miejscowej. W. IX. 1890, str. 723-729.

1892 K. Łapczyński. Wierzba ostrolistna na odsepiskach. - W. XI. 1892, str. $385-386$.

1884 W. Łopott. Materialy do flory algologicznej Warszawy. - PF. IV. 1884, str. 243-265.

1933. H. M a j d e cka. Parki Warszawy i jej okolic. Ogród Krasińskich pod względem dendrologicznym. P. Tow. Dendr. R. V, Lwów. 1933.

1929 E. M j decka-Z dziarska. Galinsoga parviflora Cav. et Galinsoga hispida B e n th. - Bull. Int. de l'Acad. Cracovie. 1929, str. 105-139, rys. 10.

1889 S. M a k owiecki. Sprawozdanie z wycieczek botanicznych odbytych w lecie 1888 w okolicy Warszawy. - W. VIII, 1889, str. 238-239.

1889 Makowiecki Przyczynek do znajomości flory okolic Warszawy. - PF,

IX C. 1889 , str. $215-236$.

1928 S. Mała chowski-モe m p i ck i. Gaj w Gucinie. - Tyg. Ilustr. 1928, nr 42. 1928 J. Miklas z ew ski. I asy i leśnictwo w Polsce. T. I, Warszawa 1928.

1953 A. Michalska. Badania cytologiczne nad rodzajem Luzula. - Acta SBP, XXII, 1. $1953 \mathrm{r}$.

1904 J. Muszyński. Ornithogalum chloranthum. - W. XXIII. 1904, str. 349 (Bielany pod Warszawą).

1905 J. Muszyński. Z wycieczki botanicznej do Czerska. - Farmacja. 1905. str. 286-287.

1931 W. Niedziałkowski. Buk na granicy zasięgu w leśnictwie Lipce. - Las Polski, nr 10-12, Warszawa. 1931.

1935 W. $\mathrm{Ni}$ edzi ałk ows ki. Monografia fitogeograficzno-leśna rezerwatów jodłowych w nadleśnictwie państwowym Łuków ze szczególnym uwzględnieniem stosunków typologicznych. - Rozpr. i Spraw. Bad. Lasów Państw., ser. 1, nr 23, 1935. 
1912 E. N ow i ck a. Arkadya. - Ziemia. 1912, str. 475-478.

1913 E. Now i ck a. Jabłonna. — Ziemia. 1913, str. 796-799.

1914 E. N ow i ck a. Gucin. - Ziemia. 1914, str. 266-268.

1826 J. .L. Orański. Mokotów. Opis Ogrodu. 1826, Warszawa.

1949 H. O rło ś. Grzyby jadalne i trujące. - Inst. Bad. Leśn., ser. D, nr 3, Warszawa 1949.

1931 A. Pi etruszyń s ka. Ogród Saski. Z cyklu: Parki Warszawy i jej okolicy.

Tow. Dendr. R. IV, Lwów. 1931.

1950 W. Pla pis. Odbudowa lasów w Warszawskim Zespole Miejskim. - Chrońmy

przyr. ojcz. VI, 1950, nr 3/4, str. $3-12$, 8 ryc,

1854 A. Połujański. Opisanie lasów Królestwa Polskiego i gubernij zachodnich

Cesarstwa Rosyjskiego pod względem historycznym, statystycznym i gospodarczym. Warszawa, T. I, 1854.

1948 J. Porębski. Parki w powiecie grójeckim. - Chrońmy przyr. ojcz. IV, 3/4, 1948, str. $42-44,5 / 6$, str. 26.

1906 M. R a ciborski. A leks ander Z a 1 e w s k i. K. XXXI, 1906, str. 454-459. 1907 M. Raciborski. Stanisław Chełchowski. K. XXXII, 1907. str. 204-207.

1911 M. R a ciborski. Drzewa, krzewy i rośliny na ziemiach polskich. - Ency-

klopedia Akad. Um. T. I. Kraków. 1911, z mapą.

1912 M. R a ciborski. Z przeszłości naszych ogrodów botanicznych. Ogrodnik.

Warszawł. 1912, str. 802-803 i 819;

1800 H. Radziwiłłowa. Le Guide d'Arcadie. Berlin. 1800.

1930 J. Raniecka. Analiza pyłkowa interglacjału na Żoliborzu w Warszawie.

- Acta Soc. Bot. Poli. VII, 2. 1932, str. 169-182, 39 ryc. i 13 tablic.

1948 I. Rejmemt-Grochowska. Historia badań flory wątrobowców w Polsce. - Acta SBP, XIX, 2, 1948, str. 251-272.

1872 J. Rostafiński. Florae Polonicae Prodromus. Uebersicht der bis jetzt im

Königreiche Polen beobachteten Phanerogamen. - Verh. d. zool.-bot. Verein in Wien, 1872, str. $81-208$.

1883 J. Rostafiński. Wojciech Jastrzębowski jako botanik.

- W. II, 1883; str. 49-51.

1886 J. Rostafiński. Krytyczne zestawienie paprotników Królestwa Polskiego. PF, VI, C, 1886, str. 235-259.

1913 J. Rostafiński. O topoli włoskiej w Polsce. - K. XXXVIII, 1913, str. $1649-1656$.

1923 J. Rostafiński. Cyprysy króla Jana III. Ogrodnictwo. 1923, str. 6.

1928 J. Rostafiński. Królewskie ogrody botaniczne króla Jana Kazimierza

w Warszawie oraz systematyczny spis roślin tam hodowanych. Kraków. PAU, 1928 , str. 100.

1917 K. Rouppert. Francilszek Kamileński. SKF. LI. 1917, str. XIII-XV. (Wspomnienie pośmiertne).

1934 Z. Róży cki. R. Kobendza, T. Paszkowski. Bielany pod Warszawą.

Przewodnik dla wycieczek geograficzno-przyrodniczych. 1934.

1924 W. Si e mas z k otocznie rosy mącznej na liściach dębu w Polsce. - Las

Polski, nr 12, Warszawa. 1924, str. 5, z 1 ryc.

1924 W. Si maszko. Fungi polonici novi et rariores. - Acta SBT, t. II, 1924.

1924 W. Siemaszko. Notatki grzyboznawczo-geograficzne. - Acta SBP, II,

1. 1924 , str. 9. 
1924-25 W. S i e ma s z ko. Notatki fitopatologiczne. I, II, III. - Choroby i szkotniki roślin. T. I. Warszawa 1924-25.

1929 W. Si em a s z o. Szara pleśń cebuli. Botrytis allii M u n n. - Roczn. Nauk Roln. i Leśn., t. XXI. Poznań 1929, str. 12, 1 tabl.

1933 W. Siemaszko. Quelques observations sur les maladies des plantes en Pollogne. - Revue de Pathologie Veg. et d'Entom. Agricole Fasc. 3, 1828. P, $139-148$.

1927-31-33 J. i W. S i e maszko. Owadorosty polskie i paleoarktyczne. (Laboulbeniales polonici et palaearctici). - Pol. Pismo Entom. VI, 3/4, 1927, X. 3/4, 1931, XII, 1/4, 1933. Lwów.

1934 W. S i e m a s z o. Zagadnienie zasięgów geograficznych chorób roślin uprawnych. - Roczn. Nauk. Ogrodn. I. 1934, str. 163-170.

1935 Siemaszko. Choroby naczyniowe wiązów. Cerastomella (Graphium) Ulmi

( Schwarz) Buisman w Polsce. - Roczn. Nauk. Ogrodn., t. II. 1395, str. 169-172, z 1 tabl.

1877 H. Skimborowi cz i W. Gerson. Wilanów. Monografia pałacu i ogrodu. Warszawa 1877.

1939 A. Skirgiełło. Polskie grzyby rurkowe (Boletaceae et partim Polyporaceae ierrestres Poloniae). - Planta Polonica VIII, 3. TNM, 1939, str. 1-124, 24 rys., 8 tabl.

1951 A. Skirgi e 11 o. Rołzaj Russula w Polsce i w krajach przyległych. - Planta Polonica. TNW, IX, 1. 1951, str. 130, 5 tabl. rys.

1952 A. Skirgiełło. Nowe stanowiska Pisolithus arenarius Alb. et Schw.

w okolicy Warszawy. - Acta SBP, XXI, 3. 1952, str. 443-446, z 3 rys.

1824 J. K. Skrodzki. O spisie roślin Ogrodu Botanicznego Un. Warszawskiego.

- Pamiętnik Um. Nauk i Sztuk. 1824, str. 260.

1922 F. K. Skupieński. Z biologił śluzowców. -K. XLVII, 1922, str. 233-243, z 3 ryc.

1867 F. M. Sobieszczański. Michał Szubert. - Encykl. Powsz.

Orgelbr. Warszawa. 1867, t. 24, str. 764-5.

1869 F. M. Sobieszczański. Ogród botaniczny w Warszawie z rysunkami Gersona. - Tyg. Ilustr. 1869. II, str. 211.

1933 M. Sok ołowski. Zabytki przyrody w okolicach Warszawy. — Liga Ochrony Przyrody, nr 1, 1933.

1887 J. Steinhaus. Materiały do flory skrytopłciowych okollic Warszawy i Ojcowa - Warsz. Uniw. Izwiestja. 1887 (po ros.). (161 mchów, 49 wątrobowców i 37 porostów).

1900 E. Strumpf. J a kub Waga. - W. XIX. 1900, str. 689-692.

1924 W. Szafer, S. Ku l czyński, B. P a w ł o w s k i. Rośliny Polskie. Książnica-Atlas. Lwów-Warszawa. 1924, str. 736.

1952 W. S z a fer. Ochrona gatunkowa roślin w Polsce. II wyd. Zakł. Och. Przyr.

Kraków, 1952, str. 39, 15 plansz barwnych, 6 tablic i 10 rys. w tekście.

1908 K. Szaf nagel. Zapiski Bryologiczne. Wyd. Tow. Przyj. Nauk w Wilnie I,

1908 , str. 74.

1882 F. S z a nior. Ogród Saski. Ogrodnik Polski. Warszawa 1882.

1893 F. Sza nior. Ogród Krasińskich. Ogrodnik Polski. Warszawa 1893.

1820 M. S z u b er t. Spis roślin Ogrodu Botanicznego Król. Warsz. Uniw. Warszawa.

1820 , str. XIV i 156. 
1821 M. Szubert. Monografia sosny pospolitej (Pinus silvestris). Roczn. Warsz. Tow. Prz. Nauk. XIV, 1821, str. 143-229, z 2 tabl.

1832 M. Szubert. Monografia bzu pospolitego (Sambucus nigra). - Sylwan III, Warszawa. 1923, str. 234-300.

1824 M. Szubert. Spis roślin ogrodu botanicznego Król.-Warsz. Uniw. Warszawa. 1824. XIV i $583 \mathrm{z}$ planem.

1827 M. Szubert. Spis roślin treybhauzowych i oranżeryowych rozmnożonych

w Ogrodzie Botanicznym Kr. Uniw. Warszawskiego 1827, str. 23.

1827 M. Szu bert. Opisanie drzew i krzewów leśnych Królestwa Polskiego. Warszawa 1927, str. XXXIV i 357.

1829 M. S z u bert. Raport o Ogrodzie Botanicznym Uniw. Warsz. w r. 1828-29.

Posiedz. publ. Uniw. Warszawa 1829, str. 19.

1938 A. S z wank e. Przyczynek do znajomości flory grzybów wodnych okolic Warszawy. - Planta Polonica. Wyd. TNW, It. VII, 1. 1938, str. 25, 6 tabl. rys.

1952 T. Szy manowski. Stare okazy wiązów szypułkowych (Ulmus laevis P a 11)

w okolicach Warszawy. - R. VIII, Sek. Dendr. PTB, 1952, str. 386-391.

1952 T. Sz y ma now s ki. Stare tulipanowce (Liriodendron tulipifera L.) koło Warszawy. R. VIII, Sek. Dendr. PTB, 1952, str. 399-400.

1893 A. Slósarski. Jerzy A l e k s a n d r owicz (80-1. jub.). - W. 1893, str. $353-356$.

1894 A. Slósarski. Kazimierz 乇a p c y ýs k i. - W. XII. 1893, str. 1-4

1895 A. Slósiarski. Feliks Berdau. Wspomnienie pośmiertne. - W. XIV, 1895, str. 769-771.

1896 A. S ló s a r s ki. O przyczynie zieloności wody w sadzawce ogrodu Saskiego. W. XV. 1896, str. 271.

1899 J. Trze b i ń s k i. Flora lasów Garwolińskich i sạsiednich okolic. - SKF PAU, XXXIV, 1899, str. 19-85.

1912 J. Trze biński. Ogrody botaniczne i Warszawski Ogród Botaniczny. Ogrodnik. Warszawa 1912.

1916 J. Trze biński. Krótkie sprawozdanie z działalności Stacji Ochrony Roślin w Warszawie od 1912-1916 r. — PF, XXIV, E 1916. s. 1-7.

1916 J. Trzebiński, W. Goriaczkowski i Z. Z we i g b a u ó w n a. Chorcby i szkodniki roślin hodowanych w Królestwie Polskim - PF, XXIII, C. 1916, str. 1-106.

1917 J. Trzebiński, Sprawozdanie z r. 1916 z dzilałalności St. Ochrony Roślin w Warszawie. PF XXIV, E. 1917, str. 12-19.

1919 J. Trzebiński, Przewodnik po Ogrodzie Botanicznym. Warszawa. 1919.

1929 J. Tworkowska. O występowaniu epifitów fakultatywnych w Polsce. Spraw. z pos. TNW, XXIr, 1929, str. 13, z 1 ryc.

1843 A (ntoni) W (a ga). O postępie aklimatyzacj:. - Biblioteka Warszawska. T. III. 1843 , str. 628 .

$1847-8 \mathrm{~J}$ a k u b W a ga. Flora polska jawnokwiatowych rodzajów czyli botaniczne opisy tak dzikich, jako hodowanych pod otwartym niebem jawnokwiatowych Królestwa Polskiego roślin, uporządkowane według zasad sztucznego układu, a poprzedzone ogólnem wyobrażeniem o znaczniejszych przyrodzonych pokrewieństwach roślinnych Królestwa. Warszawa. I, 1847, str. 1-766, II, 1848, str. 1-820.

1948 J. W e g n e r. Arkadia. - Muzeum Narodowe. Warszawa 1948, str. 74, tabl. 38. 1865 A. W (iślicki). Ogród Botaniczny. Tygodnik Ilustrowany. T. XII. 1865, str. 183. 
1925 S. Wisłouch. Sanitarno-biologiczne badania Wisły i studzien w Pruszkowie. - Pam. XII Zjazdu Lek. i Przyr. Pol. w Warszawie 1925.

1934 T. Wiśniewski i I. Rejment. Polskie gatunki rodzaju Cephalozia D u m. - Acta SBP XI, Suppl. 1934, str. 461-490, z 13 rys.

A. Wodziczko. Ogrody Botaniczne w Polsce. - Pamiętnik Wystawy Ogrodniczej w Poznaniu.

1822 (Wolfgang). O botanicznych ogrodach w Warszawie. - Pamiętnik Farmaceutyczny Wileński. T. II. Wilno. 1822, str. 113-117.

$1930 \mathrm{~S}$ t. W ó y c i cki. Wpływ mrozów roku ubiegłego na drewno i korę naszych drzew owocowych. - Ogrodnictwo. XXVI, nr 3, 1930.

1934 H. W y s o cka. Materiały do flory desmidyj z okolic Warszawy. - Acta SBP $\mathrm{XI}, \mathrm{nr} 1$, str. $119-137$.

1934 W. Wy s ocka. Remarques sur la sociologie et l'écologie des Desmidiées sphagnophiles des environs de Varsovie. - Bull. Int. de l'Acad. Pol. 1934. P. 51-68. 1949-50 H. W y s o cka. Glony Wisły na odcinku Warszawy. Cz. I. Seston. - Acta SBP XXI, 3. 1952, str. $369-400$, z 5 rys.

1861 Ks. J. W (y szyńs k i). IV i c.h a 1 S z u b e r t. Bibliot. Warszawska 1861.

1889 A. Z a lew s k i. Niektóre rzadsze rośliny z Gostyńskiego i z okolic Warszawy znalezione w lecie 1889 r. - W. VIII, 1889, str. 832-3.

1893 A. Zalewski. Kazimierz Łapczyński. Wspom. pośm. - Pam. Tow. Tatrz. XIV. 1893, str. LXXI-LXXVII.

1897 A. Z alewski. Z powodu ,Spisu roślin rzadkich albo zupełnie nieobserwowanych zebranych w okollicach Warszawy w r. 1896" W. XVI, str. 76-77. - W. XV1, 1897, str. 267.

1872 H. Z ałęs k i. J a kób Wia ga. - Tyg. Illustr. T. IX. 1872, nr 224, str. 189—190, z portr. - Przyroda i Przemysł. Warszawa 1872.

1949 K. Z a wa nowski. Wilanów. Przewodnik. Wiedza Powszechna. Warszawa 1949.

1932 A. Z ębalski. Lasy w okolicach Warszawy i niebezpieczeństwo ich zaniku. —Kronika Warszawy, zesz. 5-6. Warszawa 1932.

1916 Z. Z Zeigbaumówna. Grzybki pasożytnicze na roślinach dziko rosnących zebrane w 1912-1915 r. w Król. Polskim przez J. T r z e b i ń s k i e g o i W. G oria c z k o w s k e g o - PF XXIII C, 1916, str. 203-216.

1925 Z. Z weigbaumówna. Grzyby okolic Skierniewic. - Acta SBP II, 1925, str. $274-301$.

1936 Z. Z y s k ó w n a. Przyczynek do flory mikologicznej rezerwatu jodłowego Jata w nadleśn. państw. Łuków. - Inst. Bad. Lasów Państw, nr 21, Warszawa 1936.

1779-85 S. B. Z u g. Die Garten in Polen w pracy Hirs chfelda ,Theorie der Gartenkunst. Lipsk (1779-85)“ Po polsku: Ogrody w Polsce Atheneum 1845. T. III, str. 74-104. - Ogrody w Warszawie i jej okolicach. (Kalendarz Powszechny i Kurier Niedzielny). Warszawa 1898, nr 21-29, w skrócie - Ogrodnik Polski 1899, nr 20-21. 